This document was prepared in conjunction with work accomplished under Contract No. DE-AC09-96SR18500 with the U. S. Department of Energy.

\title{
DISCLAIMER
}

This report was prepared as an account of work sponsored by an agency of the United States Government. Neither the United States Government nor any agency thereof, nor any of their employees, nor any of their contractors, subcontractors or their employees, makes any warranty, express or implied, or assumes any legal liability or responsibility for the accuracy, completeness, or any third party's use or the results of such use of any information, apparatus, product, or process disclosed, or represents that its use would not infringe privately owned rights. Reference herein to any specific commercial product, process, or service by trade name, trademark, manufacturer, or otherwise, does not necessarily constitute or imply its endorsement, recommendation, or favoring by the United States Government or any agency thereof or its contractors or subcontractors. The views and opinions of authors expressed herein do not necessarily state or reflect those of the United States Government or any agency thereof. 
WSRC-TR-2005-00441, REV. 0

\section{CHARACTERIZATION OF CORE SAMPLES FROM A HARDENED CRUST LAYER IN TANK 4F}

September 28, 2005

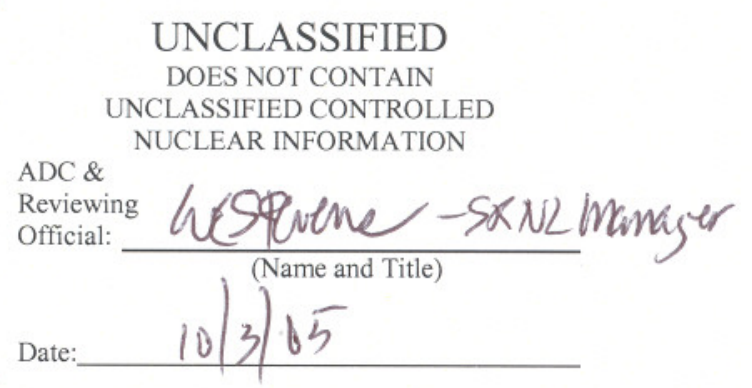

Waste Processing Technology Section Savannah River National Laboratory Aiken, SC 29808

Prepared for the U.S. Department of Energy Under Contract Number DEAC09-96SR18500
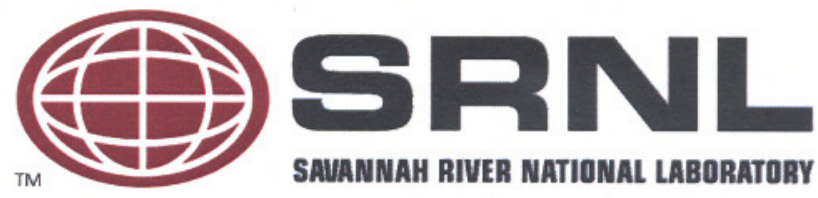


\section{DISCLAIMER}

This report was prepared for the United States Department of Energy under Contract No. DE-AC09-96SR18500 and is an account of work performed under that contract. Neither the United States Department of Energy, nor WSRC, nor any of their employees makes any warranty, expressed or implied, or assumes any legal liability or responsibility for the accuracy, completeness, or usefulness, of any information, apparatus, or product or process disclosed herein or represents that its use will not infringe privately owned rights. Reference herein to any specific commercial product, process, or service by trade name, trademark, name, manufacturer or otherwise does not necessarily constitute or imply endorsement, recommendation, or favoring of same by Westinghouse Savannah River Company or by the United States Government or any agency thereof. The views and opinions of the authors expressed herein do not necessarily state or reflect those of the United States Government or any agency thereof.

\section{Printed in the United States of America}

Prepared For

U.S. Department of Energy 
Key Words:

Solids Analysis

Supernate Analysis

Burkeite Solubility

\section{Retention: Permanent}

Key References:

Sampling Plan: CBU-LTS-2005-00031, Rev. 1 Technical Task Request: HLE-TTR-2005-046

Scoping Plan: SRNL-WPT-2005-00020, Rev. 2

Analytical Plan: SRT-LWP-2004-00015

\section{CHARACTERIZATION OF CORE SAMPLES FROM A HARDENED CRUST LAYER IN TANK 4F}

M. S. Hay, SRNL/WPT

Issue Date: September 28, 2005

Waste Processing Technology Section Savannah River National Laboratory Aiken, SC 29808

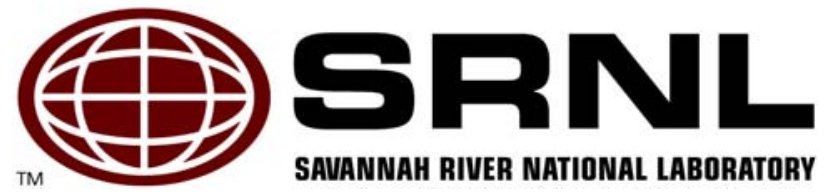


WSRC-TR-2005-00441, REV. 0

\section{REVIEWS AND APPROVALS}

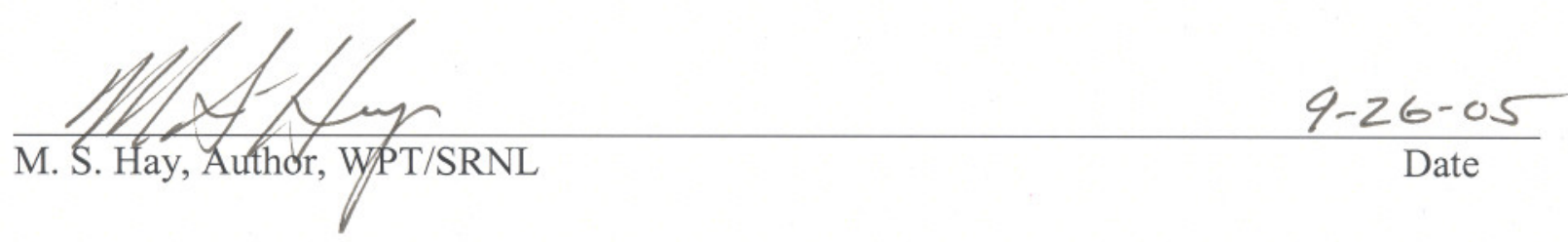

$\frac{\text { Wasterus }}{\text { W. E. Stevens, wPT Manager }} \frac{10 / 3 / 85}{\text { Date }}$

$\begin{array}{lc}\text { CSClemy } & 9-26-05 \\ \text { C. J. Coleman, ADS, Technical Reviewer } & \text { Date }\end{array}$

gloelg Chapon an

$10-3-05$

N. F. Chapman, TCP Engineer Manager

Date 


\section{TABLE OF CONTENTS}

List of Tables $\quad$ iv

List of Figures $\quad$ iv

$\begin{array}{ll}\text { List of Acronyms } & \mathbf{v}\end{array}$

SUMMARY vi vi

$\begin{array}{ll}1.0 \text { INTRODUCTION } & 1\end{array}$

2.0 SAMPLE DESCRIPTION AND PREPARATION 2

2.1 SAMPLING EVENT IN TANK 4F

2.2 SAMPLE DESCRIPTION AND SEPARATION

2.3 SAMPLE PREAPARATION FOR ANALYSIS

2.4 Weight Percent Solids ANd Density MeAsurements

3.0 RESULTS OF THE SAMPLE CHARACTERIZATION 6

3.1 GENERAL INFORMATION

6

3.2 RESUlTS OF THE ANALYSIS OF THE TANK 4F SUPERNATE SAMPLE

3.3 RESULTS OF THE ANALYSIS OF THE TANK 4F CRYSTALLINE SOLIDS

3.4 DisCUSSION OF ANALYTICAL RESULTS

4.0 BURKEITE SOLUBILITY TESTING 32

4.1 BACKGROUND ON BURKEITE SOLUBILITY

5.0 GENERAL DESCRIPTION OF ANALYTICAL PROCEDURES

5.1 INDUCTIVELy COUPLED Plasma-Atomic EMISSION SPECTROSCOPY

5.2 ATOMIC ABSORPTION SPECTROSCOPY

5.3 ION CHROMATOGRAPHY

5.4 FREE HydROXIDE AND CARBONATE TITRATIONS

\subsection{REFERENCES}




\section{List of Tables}

TABLE 2-1. C COMPOSITION OF THE ANALYTICAL REFERENCE GLASS-1 STANDARD. ...........................................5

TABLE 3-1. ABBREVIATIONS FOR ANALYTICAL METHODS USED IN DATA TABLES.................................................

TABLE 3-2. COMPOSITION OF THE SUPERNATE DiP SAMPLE FTF-436 FROM TANK 4F …...................................10

TABLE 3-3. COMPARISON OF THE SUPERNATE DIP SAMPLE FTF-436 WITH PAST ANALYSES ............................11

TABle 3-4. COMPOSITION OF THE Aqua Regia DisSOlution OF SOlidS FROM TANK 4F SAMPLE FTF-434 .12

TABle 3-5. COMPOSITION OF THE SOdIUM PEROXIDE FUSION DisSOlUtion OF SOlidS FROM TANK 4F

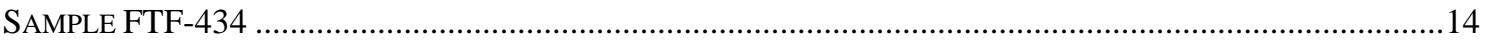

TABle 3-6. COMPOSITION OF THE Aqua Regia DisSOlution OF SOlidS FROM TANK 4F SAMPLE FTF-435 .16

TABle 3-7. COMPOSITION OF THE SODIUM PEROXIDE Fusion DisSOlUtion OF SOlidS FROM TANK 4F

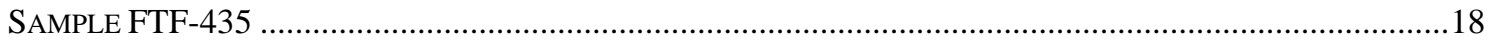

TABLE 3-8. COMPOSITION OF THE WATER CONTACT OF SOLIDS FROM TANK 4F SAMPLE $\quad$ FTF-434 ............20

TABle 3-9. COMPOSITION OF THE WATER CONTACT OF SOLIDS FROM TANK 4F SAMPLE $\quad$ FTF-435 .............22

\section{List of Figures}

FIGURE 3.1

FIGURE 3.2

FIGURE 3.3

FIGURE 3.4

FIGURE 3.5

FIGURE 3.6

FIGURE 3.7

FIGURE 3.8

FIGURE 3.9

FIGURE 3.10

FIGURE 3.11

FIGURE 3.12

FIGURE 3.13

FIGURE 3.14

FIGURE 3.15

FIGURE 3.16

FIGURE 3.17

FIGURE 3.18

FIGURE 3.19

FIGURE 3.20

FIGURE 3.21

FIGURE 3.22
X-RAY DiFFRACTION FOR SOLIDS FROM TANK 4F SAMPLE FTF-434 ……………........................24

X-RAY DIFFRACTION FOR SOLIDS FROM TANK 4F SAMPLE FTF-435 …………….......................24

SEM MICROGRAPH OF SOLIDS FROM TANK 4F SAMPLE FTF-434 (20X MAGNIFICATION) ............25

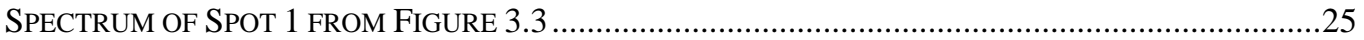

SEM MiCROGRAPH OF SOLIDS FROM TANK 4F SAMPLE FTF-434 (375X MAGNIFICATION) .........26

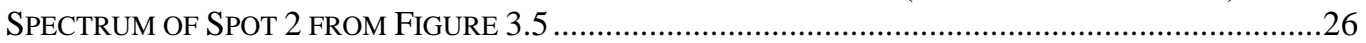

SEM MiCROGRAPH OF SOLIDS FROM TANK 4F SAMPLE FTF-434 (400X MAGNIFICATION) ..........27

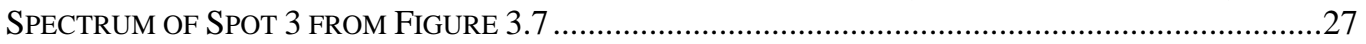

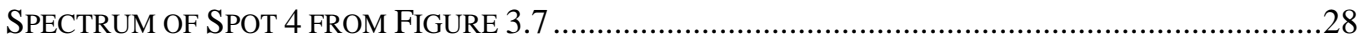

SEM MiCROGRAPH OF SOLIDS FROM TANK 4F SAMPLE FTF-435 (21X MAGNIFICATION) ......29

SPECTRUM OF SPOT 1 FROM FIGURE 3.10 ………...............................................................29

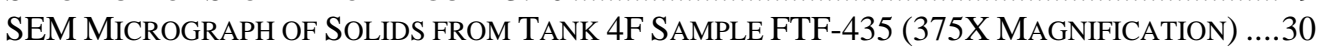

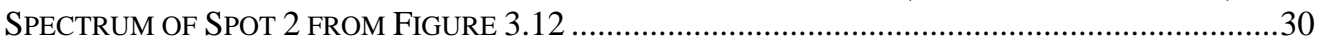

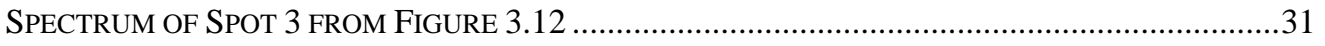

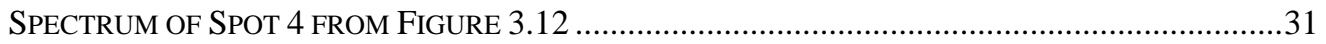

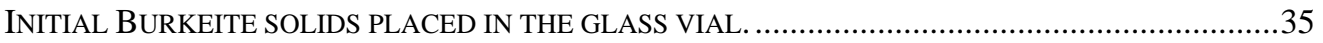

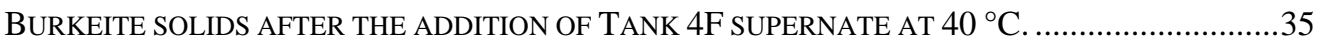

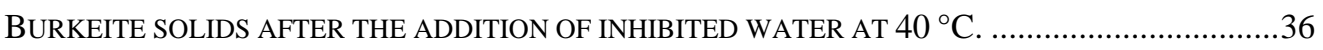

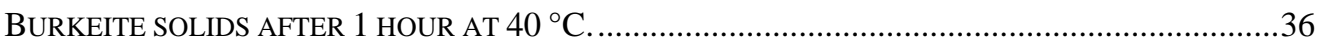

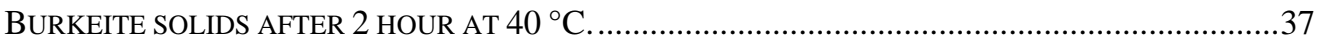

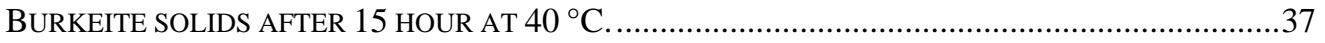

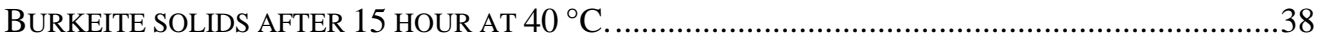




\section{List of Acronyms}

$\begin{array}{ll}\text { SRNL } & \text { Savannah River National Laboratory } \\ \text { ADS } & \text { Analytical Development Section } \\ \text { \%RSD } & \text { Percent Relative Standard Deviation } \\ \text { ICP-ES } & \text { Inductively Couple Plasma-Emission Spectroscopy } \\ \text { AA } & \text { Atomic Absorption Spectroscopy } \\ \text { ESP } & \text { Environmental Simulation Program } \\ \text { XRD } & \text { X-ray Diffraction } \\ \text { SRS } & \text { Savannah River Site } \\ \text { SEM } & \text { Scanning Electron Microscopy } \\ \text { DL } & \text { Detection Limit } \\ \text { IC } & \text { Ion Chromatography } \\ \text { ARG1 } & \text { Analytical Reference Glass 1 } \\ \text { TCP } & \text { Tank Closure Preparation } \\ \text { WPT } & \text { Waste Processing Technology }\end{array}$


WSRC-TR-2005-00441, REV. 0

\section{SUMMARY}

Waste removal operations in Tank 4F are scheduled to begin in late 2005 to provide material for Sludge Batch 5. Mining/probing operations to support installation of submersible mixer pumps encountered a hard layer of material at 45" to 50" from the bottom of the tank. Attempts at penetrating the hard layer using a manual mining tool in several different risers were not successful. A core-sampling tool was used to obtain samples of the hard crust layer in Tank 4F for characterization. Three 12” core samples and a dip sample of the supernate near the surface of the hard layer were sent to Savannah River National Laboratory (SRNL) for characterization.

X-ray Diffraction (XRD) results for the crystalline solids from both sample FTF-434 and FTF-435 identifies the major component of both samples as Burkeite $\left(\mathrm{Na}_{6}\left(\mathrm{CO}_{3}\right)\left(\mathrm{SO}_{4}\right)_{2}\right)$. All of the other data collected on the crystalline solids from the Tank 4F core samples support this conclusion.

The conditions in Tank 4F for the last twenty years have been ideal for Burkeite formation. The tank has been largely undisturbed with a tank temperature consistently above $30{ }^{\circ} \mathrm{C}$, a carbonate to sulfate molar ratio in the supernate conducive to Burkeite formation, and slow evaporation of the supernate phase.

Thermodynamic modeling and the results of a Burkeite solubility test confirm that a ratio of 1:1:12 for the volumes of Burkeite solids, supernate, and inhibited water will dissolve all of the Burkeite. These ratios could be used to remove the 6" layer of Burkeite from Tank 4F with no mixing. However, the thermodynamic modeling and the solubility test neglect the sludge layer beneath the Burkeite crust in Tank 4F. Settled sludge in Savannah River Site (SRS) high-level waste tanks usually contains greater than $75 \%$ interstitial supernate by volume. If the supernate in the sludge layer should mix into the solution used to dissolve the Burkeite, significantly more inhibited water would be needed to dissolve the Burkeite layer. Additionally, the average thickness of the Burkeite layer across the diameter of the tank may be thicker or thinner than the 6" assumed for modeling purposes. The 6" thickness assumed for the Burkeite layer was based on the 6" plug of solids found in one core sample. An average thickness greater than 6" would increase the amount of water needed to dissolve the Burkeite. 


\subsection{INTRODUCTION}

Waste removal operations in Tank 4F are scheduled to begin in late 2005 to provide material for Sludge Batch 5. Mining/probing operations to support installation of submersible mixer pumps encountered a hard layer of material at 45” to 50” from the bottom of the tank. Attempts at penetrating the hard layer using a manual mining tool in several different risers were not successful. A Sampling and Analysis $\operatorname{Plan}^{1}$ and a Technical Task Request ${ }^{2}$ were generated requesting SRNL to identify the material in the hard crust layer.

Tank 4F, a Type 1 carbon steel tank, was put into service in 1961. The tank received primarily PUREX high heat waste from 1961 through 1980. However, the tank also received some evaporator concentrate and several transfers from Tank $7 \mathrm{~F}$ and $18 \mathrm{~F}$. The last documented tank data indicate a sludge volume of $124 \mathrm{Kgal}$ (46 inches), a salt volume of 34 Kgal (12.6 inches), and a total waste volume of 516 Kgal (190 inches). ${ }^{3}$ Since 1976, the analysis of supernate dip samples show consistently high concentrations of sulfate, carbonate, and aluminate. ${ }^{4}$

Prior to sampling the tank, a document search and review of the tank history indicated the potential to form several mineral and salt species in the tank. ${ }^{5}$ The composition of the supernate phase, with high concentrations of sulfate, carbonate, and aluminate, provide conditions favorable to formation of aluminosilicates and double salts such as Burkeite, as well as sodium salts of sulfate, carbonate, nitrate, and aluminate.

A core-sampling tool was used to obtain samples of the hard crust layer in Tank 4F for characterization. Three 12" core samples and a supernate dip sample of the supernate near the surface of the hard layer were sent to SRNL for characterization. A Scoping Plan and Analytical Study Plan were generated prior to performing the characterization of the Tank 4F samples. 6,7 
WSRC-TR-2005-00441, REV. 0

\subsection{SAMPLE DESCRIPTION AND PREPARATION}

\subsection{SAMPLING EVENT IN TANK 4F}

Three 1" x 12” core samples were received at SRNL on 5-12-05. The supernate dip sample from Tank 4F was received at SRNL on 5-17-05. The three core samples were identified with the sequentially numbered sample ID's FTF-433, FTF-434, and FTF-435. The sample ID number for the supernate dip sample was FTF-436.

During the core sampling event, the sampler guide mast was lowered through the central riser of Tank 4F until coming to rest on the waste at 59" from the bottom of the tank. The first core sampler (FTF-433) was lowered into the guide and came to rest at 48" from the tank bottom. The sampler was lowered another 12" to 36" from the tank bottom and then removed from the tank. The second sampler (FTF-434) was lowered into the guide tube. The sampler stopped at 32" from the tank bottom and required pounding to move the remaining 8" to 24 ” above the tank bottom. The third sampler (FTF-435) was lowered to 24” above the tank bottom and needed several hammer blows initially, but then dropped by its own weight to $12 "$ above the tank bottom.

\subsection{SAMPLE DESCRIPTION AND SEPARATION}

At SRNL, the three core samples were loaded into the Shielded Cells. The caps were removed and the samplers emptied into plastic bottles. The following describes what was found in each core sample:

\section{FTF-433}

The first core sample contained no sample material. A thin coating of dark brown material was found in one end of the sample tube.

\section{FTF-434}

A small amount of dark brown liquid ( $30-50 \mathrm{~mL})$ poured from the sampler followed by some slow flowing dark brown sludge. A plug of solids, approximately 6” long, was encountered approximately halfway down the tube. The plug of solids was removed from the tube using a spatula and a metal rod. Although the solids were mostly coated with the dark brown sludge during the removal, some spots of white crystalline solids were clearly visible.

FTF-435

A large amount ( 100-125 mL) of thin brown liquid poured from the tube. A small plug of solids approximately 1 ” long was encountered at the end of the tube. These solids were pushed from the tube using a spatula. White crystalline solids were observed during removal of the plug.

The samples were collected in poly bottles. Since the material of interest was the crystalline phase, separation of the sludge phase from the crystalline solids was required. An observation was made that the crystalline solids were more dense than the sludge solids and 
settled more quickly. Separation of the crystalline phase was accomplished by mixing the sample and decanting the suspended sludge solids from the crystalline phase. The sludge phase was allowed to settle over night in a separate poly bottle. The clear supernate phase over the settled sludge was decanted and used to wash the crystalline phase further. The separation resulted in the isolation of a mass of dull gray to white crystalline solids. The crystalline solids were kept moist with supernate during storage. During the separation process there was no visual indication of the dissolution or degradation of the crystalline material.

The crystalline solids were composed of material ranging in size from very fine particles to large nuggets of 1/2" diameter. The large nuggets were very hard and could not be broken apart by hand pressure on the end of a metal spatula.

\subsection{SAMPLE PREAPARATION FOR ANALYSIS}

A small amount of the supernate dip sample (FTF-436) was filtered through a $0.45 \mu$ porosity filter. Portions of the filtered supernate were diluted with de-ionized distilled water or nitric acid to reduce the sample activity and allow removal from the Shielded Cells for chemical characterization. A 15-fold dilution was required on the supernate samples to meet the dose limits for the analytical laboratories. All sample preparations of the filtered supernate samples were conducted in triplicate.

Samples of the crystalline solids isolated from samples FTF-434 and FTF-435 were prepared for XRD, Scanning Electron Microscopy (SEM) analysis, and dissolution for elemental analysis. Several of the large nuggets and some of the smaller particles were removed from each sample and placed in beakers for drying. The material in each beaker was dried to constant weight. For each sample, a large nugget or several small particles were placed in a mortar and pestle and ground to a fine powder. An SEM mounting stem with sticky tape was tapped into the powder and subsequently packaged for transfer to Analytical Development Section (ADS). The mortar and pestle were cleaned and the process repeated again collecting a second SEM sample. When all of the dried material for each sample was ground to a fine powder and composited in a glass vial, a small amount was removed for XRD analysis.

Portions of ground, dried solids were prepared for analysis by aqua-regia digestion and fusion with sodium peroxide followed by uptake in hydrochloric acid. Weighed portions of the dried solids were digested and diluted to reduce activity and allow removal from the Shielded Cells. All sample preparations were conducted in triplicate.

Duplicate digestions of a glass standard containing many of the elements found in tank samples were prepared concurrently with the sample digestions. Table 2-1 lists the composition of the Analytical Reference Glass-1 (ARG-1) glass standard. ${ }^{8}$ A blank was prepared concurrently with the sample preparations consisting of the digestion reagents and incorporated any manipulations and dilutions conducted on the sample. 
A water contact of the damp crystalline solids from each sample was also conducted to allow analysis of water soluble species present in the solids. All of the solids appeared to dissolve in all of the water contact samples prepared.

\subsection{WEIGHT PERCENT SOLIDS AND DENSITY MEASUREMENTS}

The density of the filtered supernate was determined in triplicate by filling a vessel of known volume with sample and measuring the weight.

The density of the crystalline solids was determined by placing the material in a vessel of known volume and measuring the resulting weight. The interstitial space between the solids was then filled with filtered supernate from FTF-436. The crystalline solids precipitated from the supernate in the tank and therefore should not be soluble in the solution. There was no indication of significant dissolution of the solids. From the weight of solids added, the weigh of supernate added, and the density of the supernate, the density of the crystalline solids was calculated. Density measurements on the crystalline solids were only made in duplicate due to amount of material required for the analysis.

The weight percent dissolved solids in the filtered supernate from FTF-436 were determined in triplicate by drying a known weight of the material in a drying oven at $100{ }^{\circ} \mathrm{C}$ to constant weight. 
Table 2-1. Composition of the Analytical Reference Glass-1 Standard.

\begin{tabular}{|l|c|c|}
\hline Element & Wt \% in Glass & $\mathbf{~ m g / K g}$ in Glass \\
\hline $\mathrm{Al}$ & $2.50 \%$ & $2.50 \mathrm{E}+04$ \\
\hline $\mathrm{B}$ & $2.69 \%$ & $2.69 \mathrm{E}+04$ \\
\hline $\mathrm{Ba}$ & $0.079 \%$ & $7.90 \mathrm{E}+02$ \\
\hline $\mathrm{Ca}$ & $1.02 \%$ & $1.02 \mathrm{E}+04$ \\
\hline $\mathrm{Cr}$ & $0.064 \%$ & $6.40 \mathrm{E}+02$ \\
\hline $\mathrm{Cu}$ & $0.003 \%$ & $3.0 \mathrm{E}+01$ \\
\hline $\mathrm{Fe}$ & $9.79 \%$ & $9.79 \mathrm{E}+04$ \\
\hline $\mathrm{K}$ & $2.26 \%$ & $2.26 \mathrm{E}+04$ \\
\hline $\mathrm{Li}$ & $1.49 \%$ & $1.49 \mathrm{E}+04$ \\
\hline $\mathrm{Mg}$ & $0.52 \%$ & $5.2 \mathrm{E}+03$ \\
\hline $\mathrm{Mn}$ & $1.46 \%$ & $1.46 \mathrm{E}+04$ \\
\hline $\mathrm{Na}$ & $8.52 \%$ & $8.52 \mathrm{E}+04$ \\
\hline $\mathrm{Ni}$ & $0.83 \%$ & $8.3 \mathrm{E}+03$ \\
\hline $\mathrm{P}$ & $0.11 \%$ & $1.1 \mathrm{E}+03$ \\
\hline $\mathrm{Si}$ & $22.4 \%$ & $2.24 \mathrm{E}+05$ \\
\hline $\mathrm{Sr}$ & $0.003 \%$ & $3.0 \mathrm{E}+01$ \\
\hline $\mathrm{Ti}$ & $0.69 \%$ & $6.9 \mathrm{E}+03$ \\
\hline $\mathrm{Zn}$ & $0.016 \%$ & $1.6 \mathrm{E}+02$ \\
\hline $\mathrm{Zr}$ & $0.096 \%$ & $9.6 \mathrm{E}+02$ \\
\hline
\end{tabular}


WSRC-TR-2005-00441, REV. 0

\subsection{RESULTS OF THE SAMPLE CHARACTERIZATION}

\subsection{GENERAL INFORMATION}

Tables 3-2 through 3-8 provide the chemical composition of the Tank 4F samples received at SRNL. Figures 3.1 through 3.15 provide the results of the XRD and SEM analysis of the samples. Analytical results for samples use units of molarity for the supernate sample and $\mathrm{mg} / \mathrm{Kg}$ of dried solids for the solids dissolution samples. (Note: To convert values in $\mathrm{mg} / \mathrm{Kg}$ to a weight percent solids basis, divide by $1 \mathrm{E}+04$.)

The tables include the results of all replicates, blanks, and glass standards. The analytical results in tables for the solids dissolution samples include a data quality flag in the last column to indicate potential problems with the data quality. The presence of a data quality flag for an analyte does not mean the data should not be used, however, the end user of the data should be aware the result may have a higher than normal uncertainty. For waste tank sample characterization, an uncertainty of approximately $+/-15 \%$ has been found to be the normal range for the combined sampling and analytical uncertainty. ${ }^{9}$ For the Tank $4 \mathrm{~F}$ samples, the percent relative standard deviation (\%RSD) presented in the tables only includes the uncertainty associated with sub-sampling and the analytical method. It should be noted that the Tank 4F samples represent a small amount of material from a large tank. The following defines the data quality flags used in the tables:

$\mathrm{U}_{\mathrm{R}} \quad$ The percent relative standard deviation (\%RSD) for the three sample replicates was higher than 15\%. This flag indicates higher than normal uncertainty in the sample replicates.

$\mathrm{U}_{\mathrm{B}} \quad$ The analyte concentration in the blank exceeds $5 \%$ of the concentration measured in the sample. The presence of contaminants in the blank indicates the potential contamination of the samples during sample preparation. However, the contamination level in the samples would probably be random in nature and, therefore, be reflected in a higher \%RSD also.

$\mathrm{U}_{\mathrm{E}} \quad$ The analyte concentration was measured at less than ten times the detection limit (DL) for the sample. Analyte concentrations less than 10X the DL usually have a higher associated uncertainty. Again, the higher uncertainty of results with this flag would also be reflected by a higher \%RSD.

$\mathrm{U}_{\mathrm{G}} \quad$ The glass standard, prepared concurrently with the solids dissolutions of the sample, indicates a greater than $15 \%$ difference in the measured versus standard concentration. This flag can indicate potential problems during the sample preparation or with the analytical instrument measuring the analyte. 
The data tables also indicate the analytical method used to measure each analyte. Table 3-1 shows the abbreviations used for each analytical method:

Table 3-1. Abbreviations for Analytical Methods used in Data Tables

\begin{tabular}{|l|c|}
\hline Analytical Method & $\begin{array}{c}\text { Abbreviation } \\
\text { in Tables }\end{array}$ \\
\hline Inductively Coupled Plasma-Emission Spectroscopy & IE \\
\hline Ion Chromatography & IC \\
\hline Titration & T \\
\hline Atomic Absorption Cold Vapor Method & CV \\
\hline
\end{tabular}

\subsection{RESULTS OF THE ANALYSIS OF THE TANK 4F SUPERNATE SAMPLE}

Table 3-2 shows the results of the analysis of the supernate dip sample (FTF-436). The sample results indicate the Tank 4F supernate contains unusually high concentrations of sulfate and carbonate. The low \%RSD for all the major species, less than 3\% difference between the sum of the cations versus the sum of the anions, good agreement between sulfate anion concentration by IC and the sulfur concentration by ICP-ES, and no evidence of blank contamination all indicate good data quality for the analysis.

Table 3-3 compares the analysis of FTF-436 with previous two analyses of Tank 4F supernate in 2000 and 2001. The comparison shows good agreement for all the major anions in the supernate.

\subsection{RESULTS OF THE ANALYSIS OF THE TANK 4F CRYSTALLINE SOLIDS}

Tables 3-4 through 3-7 show the results of the analysis of the aqua regia and sodium peroxide fusion dissolutions of the crystalline solids obtained from the Tank 4F samples (FTF-434 and FTF-435). The data quality appears quite good with respect to the tight precision of the sample replicates, good results for the glass standards, and minimal contamination of the blank for the aqua-regia dissolution data for both samples. The comparison of the aqua-regia data for the two samples (FTF-434 and FTF-435) also shows good agreement with sodium and sulfur being the major components in both samples. The only other element detected was a small amount of iron possibly resulting from a small mount of sludge residue left on the crystalline solids after separation.

The results for the sodium peroxide fusion dissolutions of both samples show evidence of blank contamination and high \%RSD’s. The blank contamination indicates impurities in the dissolution reagents were responsible for the detection of the many elements not detected in the aqua-regia digestions. However, sulfur appears to be the dominant element in both samples, consistent with the aqua-regia digestions. Sodium values cannot be obtained from 
sodium peroxide fusion dissolutions due to the addition of sodium in the dissolution reagents. The high zirconium values result from the use of zirconium crucibles in the sample preparation.

Tables 3-8 and 3-9 show the results of the water contacts with the crystalline solids from the Tank 4F samples. The data quality for both samples appears quite good with no blank contamination and low \%RSDs for the major components of the sample. The major soluble components in both samples appear to be sulfate (or sulfur by ICP-ES) and sodium ions. On a molar concentration basis the sulfate by IC and the sulfur by ICP-ES show very good agreement for both samples ( $<5 \%$ difference). The less than detectable or very low levels of nitrate and nitrite ions in the water contacts indicate very little interstitial supernate was associated with the solids.

The results of the XRD analysis of the crystalline solids from Tank 4F in Figures 3.1 and 3.2 show a nearly one for one match with the reference spectrum for Burkeite $\left(\mathrm{Na}_{6}\left(\mathrm{CO}_{3}\right)\left(\mathrm{SO}_{4}\right)_{2}\right)$. From the XRD spectra, the samples appear to fairly pure samples of Burkeite. The presence of any significant quantity of sodium carbonate or sodium sulfate solids in the sample would be readily apparent in the XRD spectrum. Since a few peaks did not match with the Burkeite spectrum, the (+???) indicates the possibility that a small amount of an unknown compound may be present.

The SEM results in Figures 3.3 through 3.15 indicate that a compound, composed of sodium, sulfur, carbon, and oxygen, constitutes the bulk of the material making up the Tank $4 \mathrm{~F}$ crystalline solids. Small amounts of other unidentified materials were also detected. Those containing high iron content may result from the presence of sludge residue left on the crystalline solids after separation from the sludge. Each spot marked in the photographs was analyzed and has an associated spectrum shown in the following figures.

The density of the crystalline solids in sample FTF-435 was measured in duplicate with an average value of $2.23 \mathrm{~g} / \mathrm{mL}$. The density of the material in sample FTF-434 was not determined due to the smaller amount of material available and the indications from XRD and chemical analysis that both samples contained the same material.

\subsection{DISCUSSION OF ANALYTICAL RESULTS}

The XRD results for the crystalline solids from both sample FTF-434 and FTF-435 identifies the major component of both samples as Burkeite $\left(\mathrm{Na}_{6}\left(\mathrm{CO}_{3}\right)\left(\mathrm{SO}_{4}\right)_{2}\right)$. All of the other data collected on the crystalline solids from the Tank 4F core samples support this conclusion. Burkeite contains $35.4 \mathrm{wt} \%$ sodium and $16.4 \mathrm{wt} \%$ sulfur (49.3 wt\% as sulfate). The dissolutions of the crystalline solids from the Tank 4F samples found sodium and sulfur to be the major elemental components. The averaged aqua-regia data for both samples shows 34.7 wt $\%$ sodium and $17.5 \mathrm{wt} \%$ sulfur. The water contacts of the crystalline solids from FTF-434 show sodium at $35.5 \mathrm{wt} \%$, sulfur at $16.4 \mathrm{wt} \%$, and sulfate at $49.4 \mathrm{wt} \%$. Finally the SEM results indicate the major component of the samples contains only sodium, sulfur, carbon, and oxygen. 
The "purity" of the Burkeite in the samples may be an artifact of the crystalline solids recovery from the sample. No visual indication of degradation or dissolution of the crystalline solids was observed during the separation of the crystalline solids in the samples from the sludge solids. Nevertheless, small amounts of other salts more soluble than Burkeite, such as sodium salts of nitrate, nitrite, aluminate, sulfate, or carbonate, may have been selectively dissolved away from the Burkeite during the separation process. Recent water lance operation in Tank 4F to mine out areas to install mixer pumps may also have "purified” the Burkeite by dissolving away other more soluble sodium salts. The water lancing added approximately $10 \mathrm{Kgal}$ of water to the tank but lancing was not conducted in the central riser where sampling occurred. Additionally, the Tank 4F core samples represent a small amount of material from a 1 ” area in a $75 \mathrm{ft}$ diameter tank.

However, the solids phase formed in solutions high in sulfate and carbonate has been found to be dependent on the molar ratios of these two ions. ${ }^{10,11}$ The supernate in Tank 4F has a carbonate to sulfate molar ratio of $1.7: 1$.

At ratios of less than $1: 5, \mathrm{Na}_{2} \mathrm{SO}_{4}$ is the predominant solid phase At ratios between 1:5 and 5:1, Burkeite is the predominant solid phase At ratios greater than 9:1, $\mathrm{Na}_{2} \mathrm{CO}_{3} \bullet \mathrm{H}_{2} \mathrm{O}$ is the predominant solid phase

The supernate in Tank 4F, with a carbonate to sulfate molar ratio of 1.7:1, falls solidly in the range to preferentially form Burkeite. Burkeite only crystallizes from solution at temperatures over $30^{\circ} \mathrm{C}$ and, like sodium carbonate and sodium sulfate, exhibits decreasing solubility with increasing temperature. ${ }^{12}$

The conditions in Tank 4F for the last twenty years have been ideal for Burkeite formation. The tank has been largely undisturbed with a tank temperature consistently above $30{ }^{\circ} \mathrm{C}$, a carbonate to sulfate molar ratio in the supernate conducive to Burkeite formation, and slow evaporation of the supernate phase. Anecdotal information indicates that in the 2000-2001 time frame the Tank 4F cooling coils were shut down for repair and the tank temperature reached $80{ }^{\circ} \mathrm{C}$ for a period of several months. Due to the inverse solubility relationship with respect to temperature for Burkeite, the higher temperatures in the tank likely contributed to the formation of a layer of Burkeite in Tank 4F. 
Table 3-2. Composition of the Supernate Dip Sample FTF-436 from Tank 4F

\begin{tabular}{|c|c|c|c|c|c|c|}
\hline Analyte & $\begin{array}{c}\text { 1st } \\
\text { Replicate } \\
\text { (M) }\end{array}$ & $\begin{array}{c}\text { 2nd } \\
\text { Replicate } \\
\text { (M) }\end{array}$ & $\begin{array}{c}\text { 3rd } \\
\text { Replicate } \\
\text { (M) }\end{array}$ & $\begin{array}{c}\text { Average } \\
\text { (M) }\end{array}$ & \%RSD & $\begin{array}{c}\text { Blank } \\
\text { (M) }\end{array}$ \\
\hline $\mathrm{NO}_{3}^{-}$(IC) & $2.17 \mathrm{E}+00$ & $2.01 \mathrm{E}+00$ & $2.11 \mathrm{E}+00$ & $2.09 \mathrm{E}+00$ & $3.9 \%$ & $<2.5 \mathrm{E}-02$ \\
\hline $\mathrm{NO}_{2}^{-}$(IC) & $1.89 \mathrm{E}+00$ & $1.75 \mathrm{E}+00$ & $1.84 \mathrm{E}+00$ & $1.83 \mathrm{E}+00$ & $4.0 \%$ & $<3.3 \mathrm{E}-02$ \\
\hline $\mathrm{PO}_{4}{ }^{3-}$ (IC) & $<1.6 \mathrm{E}-02$ & $<1.6 \mathrm{E}-02$ & $<1.6 \mathrm{E}-02$ & $<1.6 \mathrm{E}-02$ & - & $<1.6 \mathrm{E}-02$ \\
\hline $\mathrm{SO}_{4}{ }^{2-}$ (IC) & 3.05E-01 & 2.89E-01 & 2.88E-01 & 2.94E-01 & $3.1 \%$ & $<8.0 \mathrm{E}-03$ \\
\hline $\mathrm{C}_{2} \mathrm{O}_{4}{ }^{2-}$ (IC) & $<1.7 \mathrm{E}-02$ & $<1.7 \mathrm{E}-02$ & $<1.7 \mathrm{E}-02$ & $<1.7 \mathrm{E}-02$ & - & $<1.7 \mathrm{E}-02$ \\
\hline $\mathrm{Cl}^{-}$(IC) & $<8.5 \mathrm{E}-03$ & $<8.4 \mathrm{E}-03$ & $<8.5 \mathrm{E}-03$ & $<8.5 \mathrm{E}-03$ & - & $<8.6 \mathrm{E}-03$ \\
\hline $\mathrm{F}^{-}$(IC) & $<1.6 \mathrm{E}-02$ & $<1.6 \mathrm{E}-02$ & $<1.6 \mathrm{E}-02$ & $<1.6 \mathrm{E}-02$ & - & $<1.6 \mathrm{E}-02$ \\
\hline $\mathrm{OH}_{\text {free }}^{-}(\mathrm{T})$ & $1.78 \mathrm{E}+00$ & $1.70 \mathrm{E}+00$ & $1.75 \mathrm{E}+00$ & $1.74 \mathrm{E}+00$ & $2.2 \%$ & $<1.5 \mathrm{E}-01$ \\
\hline $\mathrm{CO}_{3}{ }^{2-}(\mathrm{T})$ & 5.34E-01 & 5.18E-01 & 4.76E-01 & 5.09E-01 & $5.9 \%$ & $<1.5 \mathrm{E}-01$ \\
\hline Na (IE) & $7.37 \mathrm{E}+00$ & $7.45 \mathrm{E}+00$ & $7.45 \mathrm{E}+00$ & $7.42 \mathrm{E}+00$ & $0.6 \%$ & $<2.6 \mathrm{E}-04$ \\
\hline K (IE) & 6.54E-02 & 6.34E-02 & 6.57E-02 & 6.48E-02 & $1.9 \%$ & 3.99E-04 \\
\hline $\mathrm{Al}$ (IE) & $1.75 \mathrm{E}-01$ & $1.76 \mathrm{E}-01$ & 1.77E-01 & $1.76 \mathrm{E}-01$ & $0.5 \%$ & 4.14E-05 \\
\hline Cr (IE) & $1.82 \mathrm{E}-02$ & $1.84 \mathrm{E}-02$ & $1.82 \mathrm{E}-02$ & 1.83E-02 & $0.6 \%$ & $<8.5 \mathrm{E}-06$ \\
\hline Fe (IE) & 1.89E-05 & 1.86E-05 & 2.37E-05 & 2.04E-05 & $14 \%$ & 4.66E-06 \\
\hline Mn (IE) & $<5.4 \mathrm{E}-07$ & $<5.5 \mathrm{E}-07$ & $<5.5 \mathrm{E}-07$ & $<5.5 \mathrm{E}-07$ & - & $<5.6 \mathrm{E}-07$ \\
\hline P (IE) & $1.67 \mathrm{E}-02$ & $1.65 \mathrm{E}-02$ & $1.66 \mathrm{E}-02$ & 1.66E-02 & $0.5 \%$ & $<1.5 \mathrm{E}-04$ \\
\hline$S$ (IE) & 3.13E-01 & $3.22 \mathrm{E}-01$ & 3.17E-01 & 3.17E-01 & $1.5 \%$ & $<4.5 \mathrm{E}-05$ \\
\hline U (IE) & 5.72E-05 & 6.63E-05 & 5.52E-05 & 5.96E-05 & $10 \%$ & $<1.4 \mathrm{E}-05$ \\
\hline Hg (CV) & $<8.2 \mathrm{E}-06$ & $<8.2 \mathrm{E}-06$ & $<8.2 \mathrm{E}-06$ & $<8.2 \mathrm{E}-06$ & - & $<8.4 \mathrm{E}-06$ \\
\hline Density $_{\text {supernate }}(\mathrm{g} / \mathrm{mL})$ & 1.32 & 1.32 & 1.34 & 1.33 & $0.9 \%$ & - \\
\hline Wt\% Dissolved Solids & $38.4 \%$ & $38.5 \%$ & $38.6 \%$ & $38.5 \%$ & $0.3 \%$ & - \\
\hline
\end{tabular}


WSRC-TR-2005-00441, REV. 0

Table 3-3. Comparison of the Supernate Dip Sample FTF-436 with Past Analyses

\begin{tabular}{|l|c|c|c|}
\hline Analyte (Method) & $\begin{array}{c}\text { FTF-436 } \\
\text { Average } \\
\text { (M) }\end{array}$ & $\begin{array}{c}\mathbf{1 1 / 2 0 / 0 1} \\
\text { Analysis* } \\
\text { (M) }\end{array}$ & $\begin{array}{c}\mathbf{1 1 / 2 6 / 0 0} \\
\text { Analysis* } \\
\text { (M) }\end{array}$ \\
\hline $\mathrm{NO}_{3}{ }^{-}$(IC) & 2.09 & 2.01 & 1.81 \\
\hline $\mathrm{NO}_{2}^{-}$(IC) & 1.83 & 1.57 & 1.36 \\
\hline $\mathrm{PO}_{4}^{{ }^{-}-}$(IC) & $<0.016$ & $<0.005$ & $<0.005$ \\
\hline $\mathrm{SO}_{4}{ }^{2-}$ (IC) & 0.29 & 0.36 & 0.30 \\
\hline $\mathrm{C}_{2} \mathrm{O}_{4}{ }^{2-}$ (IC) & $<0.017$ & $<0.006$ & $<0.006$ \\
\hline $\mathrm{Cl}^{-}$(IC) & $<0.008$ & $<0.003$ & $<0.003$ \\
\hline $\mathrm{F}^{-}$(IC) & $<0.016$ & $<0.005$ & $<0.005$ \\
\hline $\mathrm{OH}_{\text {free }}^{-}$(T) & 1.74 & 2.45 & 1.83 \\
\hline $\mathrm{CO}_{3}{ }^{2-}$ (T) & 0.51 & 0.52 & 0.43 \\
\hline $\mathrm{Al}^{(\mathrm{IE})}$ & 0.18 & $<0.10^{* *}$ & 0.18 \\
\hline
\end{tabular}

* From Ntank04.xls spreadsheet $\quad * * \mathrm{Al}(\mathrm{OH})_{4}$ analysis 
WSRC-TR-2005-00441, REV. 0

Table 3-4. Composition of the Aqua Regia Dissolution of Solids from Tank 4F Sample FTF-434

\begin{tabular}{|c|c|c|c|c|c|c|c|c|c|}
\hline Analyte (Method) & $\begin{array}{c}\text { 1st } \\
\text { Replicate } \\
\text { (mg/Kg) }\end{array}$ & $\begin{array}{c}\text { 2nd } \\
\text { Replicate } \\
\text { (mg/Kg) }\end{array}$ & $\begin{array}{c}\text { 3rd } \\
\text { Replicate } \\
\text { (mg/Kg) }\end{array}$ & $\begin{array}{l}\text { Average } \\
\text { (mg/Kg) }\end{array}$ & \%RSD & $\begin{array}{c}\text { Blank } \\
(\mathbf{m g} / \mathbf{K g})\end{array}$ & $\begin{array}{l}\text { Avg Analyzed } \\
\text { Glass Std } \\
\text { (mg/Kg) }\end{array}$ & \begin{tabular}{|c|}
$\begin{array}{c}\text { Glass Std } \\
\text { Composition } \\
\text { (mg/Kg) }\end{array}$ \\
\end{tabular} & $\begin{array}{c}\text { Data } \\
\text { Quality } \\
\text { Flags } \\
\end{array}$ \\
\hline Ag (IE) & $<1.2 \mathrm{E}+02$ & $<1.1 \mathrm{E}+02$ & $<1.2 \mathrm{E}+02$ & $<1.2 \mathrm{E}+02$ & - & $<1.2 \mathrm{E}+02$ & $<1.0 \mathrm{E}+02$ & - & - \\
\hline $\mathrm{Al}$ (IE) & $<4.7 \mathrm{E}+02$ & $<4.3 \mathrm{E}+02$ & $<4.6 \mathrm{E}+02$ & $<4.5 \mathrm{E}+02$ & - & $<4.7 \mathrm{E}+02$ & $2.23 \mathrm{E}+04$ & $2.50 \mathrm{E}+04$ & - \\
\hline B (IE) & $<5.9 \mathrm{E}+02$ & $<5.5 \mathrm{E}+02$ & $<5.8 \mathrm{E}+02$ & $<5.7 \mathrm{E}+02$ & - & $<5.9 \mathrm{E}+02$ & $2.48 \mathrm{E}+04$ & $2.69 \mathrm{E}+04$ & - \\
\hline Ва (IE) & $<2.5 \mathrm{E}+02$ & $<2.4 \mathrm{E}+02$ & $<2.5 \mathrm{E}+02$ & $<2.5 \mathrm{E}+02$ & - & $<2.5 \mathrm{E}+02$ & $7.32 \mathrm{E}+02$ & $7.90 \mathrm{E}+02$ & - \\
\hline Ca (IE) & $<1.0 \mathrm{E}+02$ & $<9.3 \mathrm{E}+01$ & $<9.8 \mathrm{E}+01$ & $<9.7 \mathrm{E}+01$ & - & $<1.0 \mathrm{E}+02$ & $1.03 \mathrm{E}+04$ & $1.02 \mathrm{E}+04$ & - \\
\hline Cd (IE) & $<4.8 \mathrm{E}+01$ & $<4.4 \mathrm{E}+01$ & $<4.7 \mathrm{E}+01$ & $<4.6 \mathrm{E}+01$ & - & $<4.8 \mathrm{E}+01$ & $<3.9 \mathrm{E}+01$ & - & - \\
\hline Ce (IE) & $<1.5 \mathrm{E}+03$ & $<1.4 \mathrm{E}+03$ & $<1.5 \mathrm{E}+03$ & $<1.5 \mathrm{E}+03$ & - & $<1.5 \mathrm{E}+03$ & $<1.2 \mathrm{E}+03$ & - & - \\
\hline Cr (IE) & $<2.9 \mathrm{E}+02$ & $<2.7 \mathrm{E}+02$ & $<2.8 \mathrm{E}+02$ & $<2.8 \mathrm{E}+02$ & - & $<2.9 \mathrm{E}+02$ & $4.57 \mathrm{E}+02$ & $6.40 \mathrm{E}+02$ & $\mathrm{U}_{\mathrm{G}}$ \\
\hline $\mathrm{Cu}$ (IE) & $<1.1 \mathrm{E}+02$ & $<1.0 \mathrm{E}+02$ & $<1.1 \mathrm{E}+02$ & $<1.1 \mathrm{E}+02$ & - & $<1.1 \mathrm{E}+02$ & $<9.1 \mathrm{E}+01$ & $3.00 \mathrm{E}+01$ & $\mathrm{U}_{\mathrm{G}}$ \\
\hline $\mathrm{Fe}$ (IE) & $1.78 \mathrm{E}+03$ & $1.26 \mathrm{E}+03$ & $2.53 \mathrm{E}+03$ & $1.86 \mathrm{E}+03$ & $34 \%$ & $<1.3 \mathrm{E}+02$ & $9.84 \mathrm{E}+04$ & $9.79 \mathrm{E}+04$ & $\mathrm{U}_{\mathrm{R}}$ \\
\hline K (IE) & $<8.6 \mathrm{E}+03$ & $<8.0 \mathrm{E}+03$ & $<8.5 \mathrm{E}+03$ & $<8.4 \mathrm{E}+03$ & - & $<8.6 \mathrm{E}+03$ & $<7.7 \mathrm{E}+03$ & $2.26 \mathrm{E}+04$ & $\mathrm{U}_{\mathrm{G}}$ \\
\hline La (IE) & $<5.8 \mathrm{E}+02$ & $<5.4 \mathrm{E}+02$ & $<5.7 \mathrm{E}+02$ & $<5.6 \mathrm{E}+02$ & - & $<5.8 \mathrm{E}+02$ & $<4.7 \mathrm{E}+02$ & - & - \\
\hline Li (IE) & $<5.3 \mathrm{E}+02$ & $<4.9 \mathrm{E}+02$ & $<5.2 \mathrm{E}+02$ & $<5.2 \mathrm{E}+02$ & - & $<5.3 \mathrm{E}+02$ & $1.45 \mathrm{E}+04$ & $1.49 \mathrm{E}+04$ & - \\
\hline Mg (IE) & $<4.4 \mathrm{E}+01$ & $<4.1 \mathrm{E}+01$ & $<4.4 \mathrm{E}+01$ & $<4.3 \mathrm{E}+01$ & - & $<4.4 \mathrm{E}+01$ & $5.01 \mathrm{E}+03$ & $5.20 \mathrm{E}+03$ & - \\
\hline Mn (IE) & $<2.2 \mathrm{E}+01$ & $<2.1 \mathrm{E}+01$ & $<2.2 \mathrm{E}+01$ & $<2.1 \mathrm{E}+01$ & - & $<2.2 \mathrm{E}+01$ & $1.46 \mathrm{E}+04$ & $1.46 \mathrm{E}+04$ & - \\
\hline Mo (IE) & $<1.5 \mathrm{E}+03$ & $<1.4 \mathrm{E}+03$ & $<1.5 \mathrm{E}+03$ & $<1.4 \mathrm{E}+03$ & - & $<1.5 \mathrm{E}+03$ & $<1.2 \mathrm{E}+03$ & - & - \\
\hline $\mathrm{Na}$ (IE) & $3.42 \mathrm{E}+05$ & $3.50 \mathrm{E}+05$ & $3.48 \mathrm{E}+05$ & $3.47 \mathrm{E}+05$ & $1.2 \%$ & $<3.9 \mathrm{E}+03$ & $8.29 \mathrm{E}+04$ & $8.52 \mathrm{E}+04$ & - \\
\hline
\end{tabular}

Divide $\mathrm{mg} / \mathrm{Kg}$ values by $1 \mathrm{E}+04$ to convert to $\mathrm{wt} \%$ basis

Data Quality Flags: $\quad \mathrm{U}_{\mathrm{E}}$ - result is less than $10 \mathrm{X}$ the detection limit

$\mathrm{U}_{\mathrm{B}}$ - blank result greater than $5 \%$ of sample result

$\mathrm{U}_{\mathrm{R}}$ - \%RSD greater than $15 \%$

$\mathrm{U}_{\mathrm{G}}$ - glass std result greater than $15 \%$ from expected result 
Table 3-4. Composition of the Aqua Regia Dissolution of Solids from Tank 4F Sample FTF-434 (continued)

\begin{tabular}{|c|c|c|c|c|c|c|c|c|c|}
\hline Analyte (Method) & $\begin{array}{c}\text { 1st } \\
\text { Replicate } \\
\text { (mg/Kg) } \\
\end{array}$ & $\begin{array}{c}\text { 2nd } \\
\text { Replicate } \\
\text { (mg/Kg) }\end{array}$ & $\begin{array}{c}\text { 3rd } \\
\text { Replicate } \\
\text { (mg/Kg) }\end{array}$ & $\begin{array}{l}\text { Average } \\
\text { (mg/Kg) }\end{array}$ & \%RSD & $\begin{array}{c}\text { Blank } \\
(\mathbf{m g} / \mathbf{K g})\end{array}$ & $\begin{array}{c}\text { Avg Analyzed } \\
\text { Glass Std } \\
\text { (mg/Kg) } \\
\end{array}$ & \begin{tabular}{|c|}
$\begin{array}{c}\text { Glass Std } \\
\text { Composition } \\
\text { (mg/Kg) }\end{array}$ \\
\end{tabular} & $\begin{array}{c}\text { Data } \\
\text { Quality } \\
\text { Flags } \\
\end{array}$ \\
\hline $\mathrm{Ni}$ (IE) & $<4.4 \mathrm{E}+02$ & $<4.1 \mathrm{E}+02$ & $<4.4 \mathrm{E}+02$ & $<4.3 \mathrm{E}+02$ & - & $<4.4 \mathrm{E}+02$ & $8.35 \mathrm{E}+03$ & $8.27 \mathrm{E}+03$ & - \\
\hline $\mathrm{P}$ (IE) & $<3.0 \mathrm{E}+03$ & $<2.8 \mathrm{E}+03$ & $<2.9 \mathrm{E}+03$ & $<2.9 \mathrm{E}+03$ & - & $<3.0 \mathrm{E}+03$ & $<2.4 \mathrm{E}+03$ & $1.10 \mathrm{E}+03$ & $\mathrm{U}_{\mathrm{G}}$ \\
\hline $\mathrm{Pb}$ (IE) & $<8.4 \mathrm{E}+03$ & $<7.8 \mathrm{E}+03$ & $<8.3 \mathrm{E}+03$ & $<8.2 \mathrm{E}+03$ & - & $<8.4 \mathrm{E}+03$ & $<6.9 \mathrm{E}+03$ & - & - \\
\hline S (IE) & $1.69 \mathrm{E}+05$ & $1.73 E+05$ & $1.84 \mathrm{E}+05$ & $1.75 \mathrm{E}+05$ & $4.4 \%$ & $<9.5 \mathrm{E}+02$ & $<7.8 \mathrm{E}+02$ & - & - \\
\hline $\mathrm{Sb}$ (IE) & $<1.3 \mathrm{E}+03$ & $<1.2 \mathrm{E}+03$ & $<1.3 \mathrm{E}+03$ & $<1.2 \mathrm{E}+03$ & - & $<1.3 \mathrm{E}+03$ & $<1.1 \mathrm{E}+03$ & - & - \\
\hline Si (IE) & $<5.4 \mathrm{E}+03$ & $<5.0 \mathrm{E}+03$ & $<5.3 \mathrm{E}+03$ & $<5.2 \mathrm{E}+03$ & - & $<5.4 \mathrm{E}+03$ & $9.99 E+03$ & $2.24 \mathrm{E}+05$ & $\mathrm{U}_{\mathrm{G}}$ \\
\hline Sn (IE) & $<3.3 \mathrm{E}+03$ & $<3.1 \mathrm{E}+03$ & $<3.3 \mathrm{E}+03$ & $<3.2 \mathrm{E}+03$ & - & $<3.3 \mathrm{E}+03$ & $<2.7 \mathrm{E}+03$ & - & - \\
\hline Sr (IE) & $<1.1 \mathrm{E}+02$ & $<1.0 \mathrm{E}+02$ & $<1.1 \mathrm{E}+02$ & $<1.1 \mathrm{E}+02$ & - & $<1.1 \mathrm{E}+02$ & $1.91 \mathrm{E}+03$ & $3.00 \mathrm{E}+01$ & $\mathrm{U}_{\mathrm{G}}$ \\
\hline Ti (IE) & $<3.3 \mathrm{E}+01$ & $<3.1 \mathrm{E}+01$ & $<3.3 \mathrm{E}+01$ & $<3.2 \mathrm{E}+01$ & - & $<3.3 \mathrm{E}+01$ & $6.30 \mathrm{E}+03$ & $6.90 \mathrm{E}+03$ & - \\
\hline U (IE) & $<2.2 \mathrm{E}+03$ & $<2.0 \mathrm{E}+03$ & $<2.1 \mathrm{E}+03$ & $<2.1 \mathrm{E}+03$ & - & $<2.2 \mathrm{E}+03$ & $<1.8 \mathrm{E}+03$ & - & - \\
\hline Zn (IE) & $<7.7 \mathrm{E}+01$ & $<7.2 \mathrm{E}+01$ & $<7.6 \mathrm{E}+01$ & $<7.5 \mathrm{E}+01$ & - & $<7.7 \mathrm{E}+01$ & $1.63 \mathrm{E}+02$ & $1.60 \mathrm{E}+02$ & - \\
\hline $\mathrm{Zr}$ (IE) & $<8.9 \mathrm{E}+01$ & $<8.2 \mathrm{E}+01$ & $<8.7 \mathrm{E}+01$ & $<8.6 \mathrm{E}+01$ & - & $<8.9 \mathrm{E}+01$ & $4.72 \mathrm{E}+02$ & $9.60 \mathrm{E}+02$ & $\mathrm{U}_{\mathrm{G}}$ \\
\hline $\mathrm{Hg}(\mathrm{CV})$ & $<1.2 \mathrm{E}+02$ & $<1.1 \mathrm{E}+02$ & $<1.2 \mathrm{E}+02$ & $<1.2 \mathrm{E}+02$ & - & $<1.1 \mathrm{E}-01$ & $<1.0 \mathrm{E}+02$ & - & - \\
\hline
\end{tabular}

* Single Value

Data Quality Flags:
** Average of two replicates

$\mathrm{U}_{\mathrm{E}}$ - result is less than $10 \mathrm{X}$ the detection limit

$\mathrm{U}_{\mathrm{B}}$ - blank result greater than $5 \%$ of sample result
Divide $\mathrm{mg} / \mathrm{Kg}$ values by $1 \mathrm{E}+04$ to convert to $\mathrm{wt} \%$ basis $\mathrm{U}_{\mathrm{R}}$ - \%RSD greater than $15 \%$

$\mathrm{U}_{\mathrm{G}}-$ glass std result greater than $15 \%$ from expected result 
Table 3-5. Composition of the Sodium Peroxide Fusion Dissolution of Solids from Tank 4F Sample FTF-434

\begin{tabular}{|c|c|c|c|c|c|c|c|c|c|}
\hline Analyte (Method) & $\begin{array}{c}\text { 1st } \\
\text { Replicate } \\
\text { (mg/Kg) }\end{array}$ & $\begin{array}{c}\text { 2nd } \\
\text { Replicate } \\
\text { (mg/Kg) }\end{array}$ & $\begin{array}{c}\text { 3rd } \\
\text { Replicate } \\
\text { (mg/Kg) }\end{array}$ & $\begin{array}{l}\text { Average } \\
\text { (mg/Kg) }\end{array}$ & \%RSD & $\begin{array}{c}\text { Blank } \\
\text { (mg/Kg) }\end{array}$ & \begin{tabular}{|c} 
Avg Analyzed \\
Glass Std \\
(mg/Kg)
\end{tabular} & \begin{tabular}{|c|}
$\begin{array}{c}\text { Glass Std } \\
\text { Composition } \\
\text { (mg/Kg) }\end{array}$ \\
\end{tabular} & $\begin{array}{c}\text { Data } \\
\text { Quality } \\
\text { Flags } \\
\end{array}$ \\
\hline Ag (IE) & $1.13 \mathrm{E}+03$ & $1.07 \mathrm{E}+03$ & $1.14 \mathrm{E}+03$ & $1.11 \mathrm{E}+03$ & $3.4 \%$ & $1.09 \mathrm{E}+03$ & $9.90 \mathrm{E}+02$ & - & $\mathrm{U}_{\mathrm{E}} \mathrm{U}_{\mathrm{B}}$ \\
\hline Al (IE) & $<4.3 \mathrm{E}+02$ & $<4.1 \mathrm{E}+02$ & $<4.3 \mathrm{E}+02$ & $<4.2 \mathrm{E}+02$ & - & $<4.3 \mathrm{E}+02$ & $2.28 \mathrm{E}+04$ & $2.50 \mathrm{E}+04$ & - \\
\hline B (IE) & $<5.4 \mathrm{E}+02$ & $<5.2 \mathrm{E}+02$ & $<5.4 \mathrm{E}+02$ & $<5.3 \mathrm{E}+02$ & - & $<5.4 \mathrm{E}+02$ & $2.39 \mathrm{E}+04$ & $2.69 \mathrm{E}+04$ & - \\
\hline $\mathrm{Ba}(\mathrm{IE})$ & 4.34E+02 & $4.91 \mathrm{E}+02$ & $5.02 \mathrm{E}+02$ & $4.76 \mathrm{E}+02$ & $7.7 \%$ & $3.79 E+02$ & $1.34 \mathrm{E}+03$ & $7.90 \mathrm{E}+02$ & $\mathrm{U}_{\mathrm{G}} \mathrm{U}_{\mathrm{B}}$ \\
\hline Be (IE) & $<1.6 \mathrm{E}+01$ & $1.80 \mathrm{E}+01$ & $1.94 \mathrm{E}+01$ & $1.87 \mathrm{E}+01 * *$ & $5.3 \%$ & $1.75 \mathrm{E}+01$ & $3.33 \mathrm{E}+01$ & - & $\mathrm{U}_{\mathrm{B}}$ \\
\hline Ca (IE) & $1.80 \mathrm{E}+03$ & $1.86 \mathrm{E}+03$ & $1.93 \mathrm{E}+03$ & $1.86 \mathrm{E}+03$ & $3.5 \%$ & $1.59 \mathrm{E}+03$ & $1.15 \mathrm{E}+04$ & $1.02 \mathrm{E}+04$ & $\mathrm{U}_{\mathrm{B}}$ \\
\hline Cd (IE) & $<4.4 \mathrm{E}+01$ & $<4.2 \mathrm{E}+01$ & $<4.4 \mathrm{E}+01$ & $<4.3 \mathrm{E}+01$ & - & $<4.4 \mathrm{E}+01$ & $<5.5 \mathrm{E}+01$ & - & - \\
\hline Ce (IE) & $1.59 \mathrm{E}+04$ & $1.85 \mathrm{E}+04$ & $1.90 \mathrm{E}+04$ & $1.78 \mathrm{E}+04$ & $9.4 \%$ & $1.39 E+04$ & $1.61 \mathrm{E}+04$ & - & $\mathrm{U}_{\mathrm{B}}$ \\
\hline Cr (IE) & $<2.7 \mathrm{E}+02$ & $<2.5 \mathrm{E}+02$ & $4.01 \mathrm{E}+02$ & $4.01 \mathrm{E}+02 *$ & - & $<2.7 \mathrm{E}+02$ & $4.39 \mathrm{E}+02$ & $6.40 \mathrm{E}+02$ & $\mathrm{U}_{\mathrm{G}}$ \\
\hline $\mathrm{Cu}$ (IE) & $<1.0 \mathrm{E}+02$ & $<9.8 \mathrm{E}+01$ & $<1.0 \mathrm{E}+02$ & $<1.0 \mathrm{E}+02$ & - & $<1.0 \mathrm{E}+02$ & $<9.6 \mathrm{E}+01$ & $3.00 \mathrm{E}+01$ & $\mathrm{U}_{\mathrm{G}}$ \\
\hline Gd (IE) & $9.40 \mathrm{E}+02$ & $1.07 \mathrm{E}+03$ & $1.14 \mathrm{E}+03$ & $1.05 \mathrm{E}+03$ & $9.7 \%$ & $9.20 \mathrm{E}+02$ & $1.06 \mathrm{E}+03$ & - & $\mathrm{U}_{\mathrm{E}} \mathrm{U}_{\mathrm{B}}$ \\
\hline K (IE) & $2.66 \mathrm{E}+04$ & $3.31 \mathrm{E}+04$ & $3.13 E+04$ & $3.03 \mathrm{E}+04$ & $11 \%$ & $3.05 E+04$ & $5.10 \mathrm{E}+04$ & $2.26 \mathrm{E}+04$ & $\mathrm{U}_{\mathrm{G}} \mathrm{U}_{\mathrm{E}} \mathrm{U}_{\mathrm{B}}$ \\
\hline La (IE) & $1.84 \mathrm{E}+03$ & $2.21 \mathrm{E}+03$ & $2.23 \mathrm{E}+03$ & $2.09 \mathrm{E}+03$ & $10 \%$ & $1.52 \mathrm{E}+03$ & $1.87 \mathrm{E}+03$ & - & $\mathrm{U}_{\mathrm{E}} \mathrm{U}_{\mathrm{B}}$ \\
\hline Li (IE) & $1.54 \mathrm{E}+03$ & $1.75 \mathrm{E}+03$ & $1.87 \mathrm{E}+03$ & $1.72 \mathrm{E}+03$ & $9.7 \%$ & $1.47 \mathrm{E}+03$ & $1.43 \mathrm{E}+04$ & $1.49 \mathrm{E}+04$ & $\mathrm{U}_{\mathrm{E}} \mathrm{U}_{\mathrm{B}}$ \\
\hline Mg (IE) & $<4.1 \mathrm{E}+01$ & $<3.9 \mathrm{E}+01$ & $<4.1 \mathrm{E}+01$ & $<4.0 \mathrm{E}+01$ & - & $<4.1 \mathrm{E}+01$ & $5.30 \mathrm{E}+03$ & $5.20 \mathrm{E}+03$ & - \\
\hline Mn (IE) & $4.98 \mathrm{E}+01$ & $3.01 \mathrm{E}+01$ & $3.06 \mathrm{E}+01$ & $3.68 \mathrm{E}+01$ & $30 \%$ & $<2.0 \mathrm{E}+01$ & $1.53 \mathrm{E}+04$ & $1.46 \mathrm{E}+04$ & $\mathrm{U}_{\mathrm{R}} \mathrm{U}_{\mathrm{E}}$ \\
\hline Mo (IE) & $1.38 \mathrm{E}+03$ & $2.04 \mathrm{E}+03$ & $1.67 \mathrm{E}+03$ & $1.70 \mathrm{E}+03$ & $19 \%$ & $<1.4 \mathrm{E}+03$ & $1.87 \mathrm{E}+03$ & - & $\mathrm{U}_{\mathrm{R}} \mathrm{U}_{\mathrm{E}}$ \\
\hline
\end{tabular}

* Single Value $\quad * *$ Average of two replicates

Data Quality Flags: $\quad \mathrm{U}_{\mathrm{E}}$ - result is less than $10 \mathrm{X}$ the detection limit

$\mathrm{U}_{\mathrm{B}}$ - blank result greater than $5 \%$ of sample result
Divide $\mathrm{mg} / \mathrm{Kg}$ values by $1 \mathrm{E}+04$ to convert to $\mathrm{wt} \%$ basis $\mathrm{U}_{\mathrm{R}}-\% \mathrm{RSD}$ greater than $15 \%$

$\mathrm{U}_{\mathrm{G}}$ - glass std result greater than $15 \%$ from expected result 
WSRC-TR-2005-00441, REV. 0

Table 3-5. Composition of the Sodium Peroxide Fusion Dissolution of Solids from Tank 4F Sample FTF-434 (continued)

\begin{tabular}{|c|c|c|c|c|c|c|c|c|c|}
\hline Analyte (Method) & $\begin{array}{c}\text { 1st } \\
\text { Replicate } \\
\text { (mg/Kg) } \\
\end{array}$ & $\begin{array}{c}\text { 2nd } \\
\text { Replicate } \\
\text { (mg/Kg) }\end{array}$ & $\begin{array}{c}\text { 3rd } \\
\text { Replicate } \\
\text { (mg/Kg) } \\
\end{array}$ & $\begin{array}{l}\text { Average } \\
\text { (mg/Kg) }\end{array}$ & \%RSD & $\begin{array}{c}\text { Blank } \\
(\mathrm{mg} / \mathrm{Kg})\end{array}$ & $\begin{array}{c}\text { Avg Analyzed } \\
\text { Glass Std } \\
\text { (mg/Kg) } \\
\end{array}$ & \begin{tabular}{|c|}
$\begin{array}{c}\text { Glass Std } \\
\text { Composition } \\
\text { (mg/Kg) }\end{array}$ \\
\end{tabular} & $\begin{array}{c}\text { Data } \\
\text { Quality } \\
\text { Flags } \\
\end{array}$ \\
\hline Ni (IE) & $<4.1 \mathrm{E}+02$ & $5.75 \mathrm{E}+02$ & $4.87 \mathrm{E}+02$ & $5.31 \mathrm{E}+02 * *$ & $12 \%$ & $<4.1 \mathrm{E}+02$ & $8.78 \mathrm{E}+03$ & $8.27 \mathrm{E}+03$ & $\mathrm{U}_{\mathrm{R}}$ \\
\hline $\mathrm{P}$ (IE) & $<2.7 \mathrm{E}+03$ & $<2.6 \mathrm{E}+03$ & $<2.7 \mathrm{E}+03$ & $<2.7 \mathrm{E}+03$ & - & $<2.7 \mathrm{E}+03$ & $<1.9 \mathrm{E}+03$ & $1.10 \mathrm{E}+03$ & $\mathrm{U}_{\mathrm{G}}$ \\
\hline $\mathrm{Pb}$ (IE) & $<7.8 \mathrm{E}+03$ & $<7.4 \mathrm{E}+03$ & $<7.7 \mathrm{E}+03$ & $<7.6 \mathrm{E}+03$ & - & $<7.8 \mathrm{E}+03$ & $<7.6 \mathrm{E}+03$ & - & - \\
\hline$S$ (IE) & $1.87 \mathrm{E}+05$ & $1.96 \mathrm{E}+05$ & $1.94 \mathrm{E}+05$ & $1.92 \mathrm{E}+05$ & $2.5 \%$ & $<8.8 \mathrm{E}+02$ & $<8.6 \mathrm{E}+02$ & - & - \\
\hline Sb (IE) & $1.99 \mathrm{E}+03$ & $2.27 \mathrm{E}+03$ & $2.33 \mathrm{E}+03$ & $2.20 \mathrm{E}+03$ & $8.3 \%$ & $2.19 \mathrm{E}+03$ & $2.69 \mathrm{E}+03$ & - & $\mathrm{U}_{\mathrm{E}} \mathrm{U}_{\mathrm{B}}$ \\
\hline Si (IE) & $<5.0 \mathrm{E}+03$ & $<4.8 \mathrm{E}+03$ & $<4.9 \mathrm{E}+03$ & $4.88 E+03$ & - & $<5.0 \mathrm{E}+03$ & $2.39 \mathrm{E}+05$ & $2.24 \mathrm{E}+05$ & - \\
\hline Sn (IE) & $5.94 \mathrm{E}+03$ & $6.76 \mathrm{E}+03$ & $7.06 \mathrm{E}+03$ & $6.59 \mathrm{E}+03$ & $8.8 \%$ & $4.84 \mathrm{E}+03$ & $7.37 \mathrm{E}+03$ & - & $\mathrm{U}_{\mathrm{E}} \mathrm{U}_{\mathrm{B}}$ \\
\hline Sr (IE) & $1.51 \mathrm{E}+03$ & $1.80 \mathrm{E}+03$ & $1.82 \mathrm{E}+03$ & $1.71 \mathrm{E}+03$ & $10 \%$ & $1.25 \mathrm{E}+03$ & $1.87 \mathrm{E}+03$ & $3.00 \mathrm{E}+01$ & $\mathrm{U}_{\mathrm{G}} \mathrm{U}_{\mathrm{B}}$ \\
\hline $\mathrm{Ti}$ (IE) & $<3.1 \mathrm{E}+01$ & $<2.9 \mathrm{E}+01$ & $<3.0 \mathrm{E}+01$ & $<3.0 \mathrm{E}+01$ & - & $<3.1 \mathrm{E}+01$ & $6.92 \mathrm{E}+03$ & $6.90 \mathrm{E}+03$ & - \\
\hline U (IE) & $1.44 \mathrm{E}+04$ & $1.35 \mathrm{E}+04$ & $1.64 \mathrm{E}+04$ & $1.48 \mathrm{E}+04$ & $10 \%$ & $1.52 \mathrm{E}+04$ & $1.50 \mathrm{E}+04$ & - & $\mathrm{U}_{\mathrm{E}} \mathrm{U}_{\mathrm{B}}$ \\
\hline V (IE) & $2.94 \mathrm{E}+02$ & $1.22 \mathrm{E}+03$ & $3.46 \mathrm{E}+03$ & $1.66 \mathrm{E}+03$ & $98 \%$ & $4.31 \mathrm{E}+02$ & $4.08 \mathrm{E}+02$ & - & $\mathrm{U}_{\mathrm{R}} \mathrm{U}_{\mathrm{E}} \mathrm{U}_{\mathrm{B}}$ \\
\hline Zn (IE) & $3.50 \mathrm{E}+02$ & $4.23 \mathrm{E}+02$ & $4.21 \mathrm{E}+02$ & $3.98 \mathrm{E}+02$ & $10 \%$ & $3.41 \mathrm{E}+02$ & $3.99 \mathrm{E}+02$ & $1.60 \mathrm{E}+02$ & $\mathrm{U}_{\mathrm{G}} \mathrm{U}_{\mathrm{E}} \mathrm{U}_{\mathrm{B}}$ \\
\hline $\mathrm{Zr}$ (IE) & $1.05 \mathrm{E}+05$ & $7.84 \mathrm{E}+04$ & $8.38 \mathrm{E}+04$ & $8.91 \mathrm{E}+04$ & $16 \%$ & $9.99 \mathrm{E}+04$ & $3.37 E+04$ & $9.60 \mathrm{E}+02$ & $\mathrm{U}_{\mathrm{R}} \mathrm{U}_{\mathrm{G}}$ \\
\hline
\end{tabular}

\section{* Single Value $\quad$ ** Average of two replicates}

Data Quality Flags:
$\mathrm{U}_{\mathrm{E}}$ - result is less than $10 \mathrm{X}$ the detection limit

$\mathrm{U}_{\mathrm{B}}$ - blank result greater than $5 \%$ of sample result
Divide $\mathrm{mg} / \mathrm{Kg}$ values by $1 \mathrm{E}+04$ to convert to $\mathrm{wt} \%$ basis $\mathrm{U}_{\mathrm{R}}-\% \mathrm{RSD}$ greater than $15 \%$

$\mathrm{U}_{\mathrm{G}}-$ glass std result greater than $15 \%$ from expected result 
WSRC-TR-2005-00441, REV. 0

Table 3-6. Composition of the Aqua Regia Dissolution of Solids from Tank 4F Sample FTF-435

\begin{tabular}{|c|c|c|c|c|c|c|c|c|c|}
\hline Analyte (Method) & $\begin{array}{c}\text { 1st } \\
\text { Replicate } \\
\text { (mg/Kg) }\end{array}$ & $\begin{array}{c}\text { 2nd } \\
\text { Replicate } \\
\text { (mg/Kg) }\end{array}$ & $\begin{array}{c}\text { 3rd } \\
\text { Replicate } \\
\text { (mg/Kg) }\end{array}$ & $\begin{array}{l}\text { Average } \\
\text { (mg/Kg) }\end{array}$ & $\%$ RSD & $\begin{array}{c}\text { Blank } \\
(\mathbf{m g} / \mathbf{K g})\end{array}$ & \begin{tabular}{|c|}
$\begin{array}{c}\text { Avg Analyzed } \\
\text { Glass Std } \\
\text { (mg/Kg) }\end{array}$ \\
\end{tabular} & \begin{tabular}{|c|}
$\begin{array}{c}\text { Glass Std } \\
\text { Composition } \\
(\mathrm{mg} / \mathrm{Kg})\end{array}$ \\
\end{tabular} & $\begin{array}{c}\text { Data } \\
\text { Quality } \\
\text { Flags } \\
\end{array}$ \\
\hline Ag (IE) & $<1.2 \mathrm{E}+02$ & $<1.0 \mathrm{E}+02$ & $<1.1 \mathrm{E}+02$ & $<1.1 \mathrm{E}+02$ & - & $<1.2 \mathrm{E}+02$ & $<1.1 \mathrm{E}+02$ & - & - \\
\hline Al (IE) & $<4.7 \mathrm{E}+02$ & $<3.9 \mathrm{E}+02$ & $<4.3 \mathrm{E}+02$ & $<4.3 \mathrm{E}+02$ & - & $<4.7 \mathrm{E}+02$ & $2.37 \mathrm{E}+04$ & $2.50 \mathrm{E}+04$ & - \\
\hline B (IE) & $<5.9 \mathrm{E}+02$ & $<4.9 \mathrm{E}+02$ & $<5.4 \mathrm{E}+02$ & $<5.4 \mathrm{E}+02$ & - & $<5.9 \mathrm{E}+02$ & $2.60 \mathrm{E}+04$ & $2.69 \mathrm{E}+04$ & - \\
\hline $\mathrm{Ba}$ (IE) & $<2.6 \mathrm{E}+02$ & $<2.1 \mathrm{E}+02$ & $<2.4 \mathrm{E}+02$ & $<2.4 \mathrm{E}+02$ & - & $<2.6 \mathrm{E}+02$ & $7.65 \mathrm{E}+02$ & $7.90 \mathrm{E}+02$ & - \\
\hline $\mathrm{Ca}$ (IE) & $<1.0 \mathrm{E}+02$ & $<8.4 \mathrm{E}+01$ & $<9.2 \mathrm{E}+01$ & $<9.2 \mathrm{E}+01$ & - & $<1.0 \mathrm{E}+02$ & $1.03 \mathrm{E}+04$ & $1.02 \mathrm{E}+04$ & - \\
\hline Cd (IE) & $<4.8 \mathrm{E}+01$ & $<4.0 \mathrm{E}+01$ & $<4.4 \mathrm{E}+01$ & $<4.4 \mathrm{E}+01$ & - & $<4.8 \mathrm{E}+01$ & $<4.2 \mathrm{E}+01$ & - & - \\
\hline $\mathrm{Ce}$ (IE) & $<1.5 \mathrm{E}+03$ & $<1.3 \mathrm{E}+03$ & $<1.4 \mathrm{E}+03$ & $<1.4 \mathrm{E}+03$ & - & $<1.5 \mathrm{E}+03$ & $<1.3 \mathrm{E}+03$ & - & - \\
\hline Cr (IE) & $<2.9 \mathrm{E}+02$ & $<2.4 \mathrm{E}+02$ & $<2.7 \mathrm{E}+02$ & $<2.7 \mathrm{E}+02$ & - & $<2.9 \mathrm{E}+02$ & $<4.5 \mathrm{E}+02$ & $6.40 \mathrm{E}+02$ & $\mathrm{U}_{\mathrm{G}}$ \\
\hline $\mathrm{Cu}$ (IE) & $<1.1 \mathrm{E}+02$ & $<9.3 \mathrm{E}+01$ & $<1.0 \mathrm{E}+02$ & $<1.0 \mathrm{E}+02$ & - & $<1.1 \mathrm{E}+02$ & $<6.4 \mathrm{E}+01$ & $3.00 \mathrm{E}+01$ & $\mathrm{U}_{\mathrm{G}}$ \\
\hline Fe (IE) & $6.59 \mathrm{E}+02$ & $6.39 \mathrm{E}+02$ & $5.28 \mathrm{E}+02$ & $6.09 \mathrm{E}+02$ & $12 \%$ & $<1.3 \mathrm{E}+02$ & $9.85 \mathrm{E}+04$ & $9.79 E+04$ & - \\
\hline K (IE) & $<8.7 \mathrm{E}+03$ & $<7.2 \mathrm{E}+03$ & $<8.0 \mathrm{E}+03$ & $<8.0 \mathrm{E}+03$ & - & $<8.7 \mathrm{E}+03$ & $1.62 \mathrm{E}+04$ & $2.26 \mathrm{E}+04$ & $\mathrm{U}_{\mathrm{G}}$ \\
\hline La (IE) & $<5.8 \mathrm{E}+02$ & $<4.8 \mathrm{E}+02$ & $<5.3 \mathrm{E}+02$ & $<5.3 \mathrm{E}+02$ & - & $<5.8 \mathrm{E}+02$ & $<5.1 \mathrm{E}+02$ & - & - \\
\hline Li (IE) & $<5.3 \mathrm{E}+02$ & $<4.5 \mathrm{E}+02$ & $<4.9 \mathrm{E}+02$ & $<4.9 \mathrm{E}+02$ & - & $<5.3 \mathrm{E}+02$ & $1.48 \mathrm{E}+04$ & $1.49 \mathrm{E}+04$ & - \\
\hline $\mathrm{Mg}$ (IE) & $<4.4 \mathrm{E}+01$ & $<3.7 \mathrm{E}+01$ & $<4.1 \mathrm{E}+01$ & $<4.1 \mathrm{E}+01$ & - & $<4.4 \mathrm{E}+01$ & $5.12 \mathrm{E}+03$ & $5.20 \mathrm{E}+03$ & - \\
\hline Mn (IE) & $<2.2 \mathrm{E}+01$ & $<1.9 \mathrm{E}+01$ & $<2.0 \mathrm{E}+01$ & $<2.0 \mathrm{E}+01$ & - & $<2.2 \mathrm{E}+01$ & $1.46 \mathrm{E}+04$ & $1.46 \mathrm{E}+04$ & - \\
\hline Mo (IE) & $<1.5 \mathrm{E}+03$ & $<1.2 \mathrm{E}+03$ & $<1.4 \mathrm{E}+03$ & $<1.4 \mathrm{E}+03$ & - & $<1.5 \mathrm{E}+03$ & $<1.3 \mathrm{E}+03$ & - & - \\
\hline $\mathrm{Na}$ (IE) & $3.54 \mathrm{E}+05$ & $3.33 E+05$ & $3.55 \mathrm{E}+05$ & $3.47 \mathrm{E}+05$ & $3.6 \%$ & $<4.0 \mathrm{E}+03$ & $8.43 E+04$ & $8.52 E+04$ & - \\
\hline
\end{tabular}

Divide $\mathrm{mg} / \mathrm{Kg}$ values by $1 \mathrm{E}+04$ to convert to $\mathrm{wt} \%$ basis

Data Quality Flags: $\quad U_{\mathrm{E}}-$ result is less than $10 \mathrm{X}$ the detection limit

$\mathrm{U}_{\mathrm{B}}$ - blank result greater than $5 \%$ of sample result

$\mathrm{U}_{\mathrm{R}}$ - \%RSD greater than $15 \%$

$\mathrm{U}_{\mathrm{G}}$ - glass std result greater than $15 \%$ from expected result 
Table 3-6. Composition of the Aqua Regia Dissolution of Solids from Tank 4F Sample FTF-435 (continued)

\begin{tabular}{|c|c|c|c|c|c|c|c|c|c|}
\hline Analyte (Method) & $\begin{array}{c}\text { 1st } \\
\text { Replicate } \\
\text { (mg/Kg) } \\
\end{array}$ & $\begin{array}{c}\text { 2nd } \\
\text { Replicate } \\
\text { (mg/Kg) }\end{array}$ & $\begin{array}{c}\text { 3rd } \\
\text { Replicate } \\
\text { (mg/Kg) }\end{array}$ & $\begin{array}{l}\text { Average } \\
\text { (mg/Kg) }\end{array}$ & \%RSD & $\begin{array}{c}\text { Blank } \\
\text { (mg/Kg) }\end{array}$ & $\begin{array}{c}\text { Avg Analyzed } \\
\text { Glass Std } \\
\text { (mg/Kg) }\end{array}$ & \begin{tabular}{|c|}
$\begin{array}{c}\text { Glass Std } \\
\text { Composition } \\
\text { (mg/Kg) }\end{array}$ \\
\end{tabular} & $\begin{array}{c}\text { Data } \\
\text { Quality } \\
\text { Flags } \\
\end{array}$ \\
\hline $\mathrm{Ni}$ (IE) & $<4.4 \mathrm{E}+02$ & $<3.7 \mathrm{E}+02$ & $<4.1 \mathrm{E}+02$ & $<4.1 \mathrm{E}+02$ & - & $<4.4 \mathrm{E}+02$ & $8.29 \mathrm{E}+03$ & $8.27 \mathrm{E}+03$ & - \\
\hline $\mathrm{P}$ (IE) & $<3.0 \mathrm{E}+03$ & $<2.5 \mathrm{E}+03$ & $<2.7 \mathrm{E}+03$ & $<2.7 \mathrm{E}+03$ & - & $<3.0 \mathrm{E}+03$ & $<1.9 \mathrm{E}+03$ & $1.10 \mathrm{E}+03$ & $\mathrm{U}_{\mathrm{G}}$ \\
\hline $\mathrm{Pb}$ (IE) & $<8.5 \mathrm{E}+03$ & $<7.1 \mathrm{E}+03$ & $<7.8 \mathrm{E}+03$ & $<7.8 \mathrm{E}+03$ & - & $<8.5 \mathrm{E}+03$ & $<7.4 \mathrm{E}+03$ & - & - \\
\hline S (IE) & $1.85 \mathrm{E}+05$ & $1.69 \mathrm{E}+05$ & $1.80 \mathrm{E}+05$ & $1.78 \mathrm{E}+05$ & $4.6 \%$ & $<9.6 \mathrm{E}+02$ & $<8.4 \mathrm{E}+02$ & - & - \\
\hline Sb (IE) & $<1.3 \mathrm{E}+03$ & $<1.1 \mathrm{E}+03$ & $<1.2 \mathrm{E}+03$ & $<1.2 \mathrm{E}+03$ & - & $<1.3 \mathrm{E}+03$ & $<1.1 \mathrm{E}+03$ & - & - \\
\hline Si (IE) & $<5.4 \mathrm{E}+03$ & $<4.5 \mathrm{E}+03$ & $<5.0 \mathrm{E}+03$ & $<5.0 \mathrm{E}+03$ & - & $<5.4 \mathrm{E}+03$ & $1.18 \mathrm{E}+05$ & $2.24 \mathrm{E}+05$ & $\mathrm{U}_{\mathrm{G}}$ \\
\hline Sn (IE) & $<3.3 \mathrm{E}+03$ & $<2.8 \mathrm{E}+03$ & $<3.1 \mathrm{E}+03$ & $<3.1 \mathrm{E}+03$ & - & $<3.3 \mathrm{E}+03$ & $<2.9 \mathrm{E}+03$ & - & - \\
\hline Sr (IE) & $<1.1 \mathrm{E}+02$ & $<9.3 \mathrm{E}+01$ & $<1.0 \mathrm{E}+02$ & $<1.0 \mathrm{E}+02$ & - & $<1.1 \mathrm{E}+02$ & $9.65 \mathrm{E}+02$ & $3.00 \mathrm{E}+01$ & $\mathrm{U}_{\mathrm{G}}$ \\
\hline Ti (IE) & $<3.3 \mathrm{E}+01$ & $<2.8 \mathrm{E}+01$ & $<3.1 \mathrm{E}+01$ & $<3.1 \mathrm{E}+01$ & - & $<3.3 \mathrm{E}+01$ & $6.69 \mathrm{E}+03$ & $6.90 \mathrm{E}+03$ & - \\
\hline U (IE) & $<2.2 \mathrm{E}+03$ & $<1.8 \mathrm{E}+03$ & $<2.0 \mathrm{E}+03$ & $<2.0 \mathrm{E}+03$ & - & $<2.2 \mathrm{E}+03$ & $<1.9 \mathrm{E}+03$ & - & - \\
\hline Zn (IE) & $<7.8 \mathrm{E}+01$ & $<6.5 \mathrm{E}+01$ & $<7.1 \mathrm{E}+01$ & $<7.1 \mathrm{E}+01$ & - & $<7.8 \mathrm{E}+01$ & $1.57 \mathrm{E}+02$ & $1.60 \mathrm{E}+02$ & - \\
\hline Zr (IE) & $<8.9 \mathrm{E}+01$ & $<7.4 \mathrm{E}+01$ & $<8.2 \mathrm{E}+01$ & $<8.2 \mathrm{E}+01$ & - & $<8.9 \mathrm{E}+01$ & $7.40 \mathrm{E}+02$ & $9.60 \mathrm{E}+02$ & $\mathrm{U}_{\mathrm{G}}$ \\
\hline $\mathrm{Hg}(\mathrm{CV})$ & $<1.2 \mathrm{E}+02$ & $<1.0 \mathrm{E}+02$ & $<1.1 \mathrm{E}+02$ & $<1.1 \mathrm{E}+02$ & - & $<1.1 \mathrm{E}-01$ & $<1.0 \mathrm{E}+02$ & - & - \\
\hline
\end{tabular}

Divide $\mathrm{mg} / \mathrm{Kg}$ values by $1 \mathrm{E}+04$ to convert to wt $\%$ basis

Data Quality Flags: $\quad U_{E}$ - result is less than $10 X$ the detection limit

$U_{B}$ - blank result greater than $5 \%$ of sample result
$\mathrm{U}_{\mathrm{R}}$ - \%RSD greater than $15 \%$

$\mathrm{U}_{\mathrm{G}}$ - glass std result greater than $15 \%$ from expected result 
Table 3-7. Composition of the Sodium Peroxide Fusion Dissolution of Solids from Tank 4F Sample FTF-435

\begin{tabular}{|c|c|c|c|c|c|c|c|c|c|}
\hline Analyte (Method) & $\begin{array}{c}\text { 1st } \\
\text { Replicate } \\
\text { (mg/Kg) }\end{array}$ & $\begin{array}{c}\text { 2nd } \\
\text { Replicate } \\
\text { (mg/Kg) }\end{array}$ & $\begin{array}{c}\text { 3rd } \\
\text { Replicate } \\
\text { (mg/Kg) }\end{array}$ & $\begin{array}{l}\text { Average } \\
\text { (mg/Kg) }\end{array}$ & \%RSD & $\begin{array}{c}\text { Blank } \\
\text { (mg/Kg) }\end{array}$ & \begin{tabular}{|c} 
Avg Analyzed \\
Glass Std \\
(mg/Kg)
\end{tabular} & \begin{tabular}{|c|}
$\begin{array}{c}\text { Glass Std } \\
\text { Composition } \\
\text { (mg/Kg) }\end{array}$ \\
\end{tabular} & $\begin{array}{c}\text { Data } \\
\text { Quality } \\
\text { Flags } \\
\end{array}$ \\
\hline Ag (IE) & $1.53 \mathrm{E}+03$ & $1.56 \mathrm{E}+03$ & $1.40 \mathrm{E}+03$ & $1.50 \mathrm{E}+03$ & $5.7 \%$ & $1.40 \mathrm{E}+03$ & $8.33 \mathrm{E}+02$ & - & $\mathrm{U}_{\mathrm{B}}$ \\
\hline Al (IE) & $<4.1 \mathrm{E}+02$ & $<4.1 \mathrm{E}+02$ & $<4.1 \mathrm{E}+02$ & $<4.1 \mathrm{E}+02$ & - & $<4.1 \mathrm{E}+02$ & $2.34 \mathrm{E}+04$ & $2.50 \mathrm{E}+04$ & - \\
\hline B (IE) & $<5.2 \mathrm{E}+02$ & $<5.1 \mathrm{E}+02$ & $<5.2 \mathrm{E}+02$ & $<5.2 \mathrm{E}+02$ & - & $<5.2 \mathrm{E}+02$ & $2.55 \mathrm{E}+04$ & $2.69 \mathrm{E}+04$ & $\mathrm{U}_{\mathrm{E}}$ \\
\hline $\mathrm{Ba}(\mathrm{IE})$ & $2.56 \mathrm{E}+02$ & $3.14 \mathrm{E}+02$ & $2.30 \mathrm{E}+02$ & $2.67 \mathrm{E}+02$ & $16 \%$ & $<2.3 \mathrm{E}+02$ & $9.10 \mathrm{E}+02$ & $7.90 \mathrm{E}+02$ & $\mathrm{U}_{\mathrm{R}} \mathrm{U}_{\mathrm{G}}$ \\
\hline Be (IE) & $<1.5 \mathrm{E}+01$ & $<1.5 \mathrm{E}+01$ & $<1.5 \mathrm{E}+01$ & $<1.5 \mathrm{E}+01$ & - & $<1.5 \mathrm{E}+01$ & $2.13 \mathrm{E}+01$ & - & - \\
\hline Ca (IE) & $1.64 \mathrm{E}+03$ & $1.71 \mathrm{E}+03$ & $1.69 \mathrm{E}+03$ & $1.68 \mathrm{E}+03$ & $2.1 \%$ & $1.58 \mathrm{E}+03$ & $1.09 \mathrm{E}+04$ & $1.02 \mathrm{E}+04$ & $\mathrm{U}_{\mathrm{B}}$ \\
\hline Cd (IE) & $<4.2 \mathrm{E}+01$ & $<4.2 \mathrm{E}+01$ & $<4.2 \mathrm{E}+01$ & $<4.2 \mathrm{E}+01$ & - & $<4.2 \mathrm{E}+01$ & $<4.1 \mathrm{E}+01$ & - & - \\
\hline Ce (IE) & $1.01 \mathrm{E}+04$ & $1.20 \mathrm{E}+04$ & $8.70 \mathrm{E}+03$ & $1.03 \mathrm{E}+04$ & $16 \%$ & $8.13 E+03$ & $5.77 \mathrm{E}+03$ & - & $\mathrm{U}_{\mathrm{R}} \mathrm{U}_{\mathrm{E}} \mathrm{U}_{\mathrm{B}}$ \\
\hline Cr (IE) & $<2.6 \mathrm{E}+02$ & $<2.5 \mathrm{E}+02$ & $<2.6 \mathrm{E}+02$ & $<2.5 \mathrm{E}+02$ & - & $<2.6 \mathrm{E}+02$ & $6.59 \mathrm{E}+02$ & $6.40 \mathrm{E}+02$ & $\mathrm{U}_{\mathrm{G}}$ \\
\hline $\mathrm{Cu}$ (IE) & $<9.8 \mathrm{E}+01$ & $<9.7 \mathrm{E}+01$ & $<9.8 \mathrm{E}+01$ & $<9.8 \mathrm{E}+01$ & - & $<9.8 \mathrm{E}+01$ & $<6.3 \mathrm{E}+01$ & $3.00 \mathrm{E}+01$ & $\mathrm{U}_{\mathrm{G}}$ \\
\hline Fe (IE) & $1.19 \mathrm{E}+03$ & $1.04 \mathrm{E}+03$ & $9.31 \mathrm{E}+02$ & $1.05 \mathrm{E}+03$ & $12 \%$ & $2.89 \mathrm{E}+02$ & $9.89 \mathrm{E}+04$ & $9.79 \mathrm{E}+04$ & $\mathrm{U}_{\mathrm{B}}$ \\
\hline Gd (IE) & $6.30 \mathrm{E}+02$ & $7.81 \mathrm{E}+02$ & $4.86 \mathrm{E}+02$ & $6.32 \mathrm{E}+02$ & $23 \%$ & $4.90 \mathrm{E}+02$ & $3.65 E+02$ & - & $\mathrm{U}_{\mathrm{R}} \mathrm{U}_{\mathrm{E}} \mathrm{U}_{\mathrm{B}}$ \\
\hline K (IE) & $1.94 \mathrm{E}+04$ & $2.30 \mathrm{E}+04$ & $8.88 \mathrm{E}+03$ & $1.71 \mathrm{E}+04$ & $43 \%$ & $1.28 \mathrm{E}+04$ & $2.84 \mathrm{E}+04$ & $2.26 \mathrm{E}+04$ & $\mathrm{U}_{\mathrm{R}} \mathrm{U}_{\mathrm{G}} \mathrm{U}_{\mathrm{E}} \mathrm{U}_{\mathrm{B}}$ \\
\hline La (IE) & $9.51 \mathrm{E}+02$ & $1.21 \mathrm{E}+03$ & $7.98 \mathrm{E}+02$ & $9.86 \mathrm{E}+02$ & $21 \%$ & $7.49 \mathrm{E}+02$ & $5.00 \mathrm{E}+02$ & - & $\mathrm{U}_{\mathrm{R}} \mathrm{U}_{\mathrm{E}} \mathrm{U}_{\mathrm{B}}$ \\
\hline Li (IE) & $9.54 \mathrm{E}+02$ & $1.21 \mathrm{E}+03$ & $7.54 \mathrm{E}+02$ & $9.73 \mathrm{E}+02$ & $23 \%$ & $7.69 \mathrm{E}+02$ & $1.45 \mathrm{E}+04$ & $1.49 \mathrm{E}+04$ & $\mathrm{U}_{\mathrm{R}} \mathrm{U}_{\mathrm{E}} \mathrm{U}_{\mathrm{B}}$ \\
\hline Mg (IE) & $<3.9 \mathrm{E}+01$ & $<3.9 \mathrm{E}+01$ & $<3.9 \mathrm{E}+01$ & $<3.9 \mathrm{E}+01$ & - & $<3.9 \mathrm{E}+01$ & $5.16 \mathrm{E}+03$ & $5.20 \mathrm{E}+03$ & - \\
\hline Mn (IE) & $<2.0 \mathrm{E}+01$ & $<1.9 \mathrm{E}+01$ & $<2.0 \mathrm{E}+01$ & $<2.0 \mathrm{E}+01$ & - & $<2.0 \mathrm{E}+01$ & $1.47 \mathrm{E}+04$ & $1.46 \mathrm{E}+04$ & - \\
\hline Mo (IE) & $<1.3 \mathrm{E}+03$ & $<1.3 \mathrm{E}+03$ & $<1.3 \mathrm{E}+03$ & $<1.3 \mathrm{E}+03$ & - & $<1.3 \mathrm{E}+03$ & $<1.3 \mathrm{E}+03$ & - & - \\
\hline
\end{tabular}

* Single Value $\quad * *$ Average of two replicates

Data Quality Flags: $\quad \mathrm{U}_{\mathrm{E}}-$ result is less than $10 \mathrm{X}$ the detection limit

$\mathrm{U}_{\mathrm{B}}$ - blank result greater than $5 \%$ of sample result
Divide $\mathrm{mg} / \mathrm{Kg}$ values by $1 \mathrm{E}+04$ to convert to $\mathrm{wt} \%$ basis $\mathrm{U}_{\mathrm{R}}$ - \%RSD greater than $15 \%$

$\mathrm{U}_{\mathrm{G}}$ - glass std result greater than $15 \%$ from expected result 
WSRC-TR-2005-00441, REV. 0

Table 3-7. Composition of the Sodium Peroxide Fusion Dissolution of Solids from Tank 4F Sample FTF-435 (continued)

\begin{tabular}{|c|c|c|c|c|c|c|c|c|c|}
\hline Analyte (Method) & $\begin{array}{c}\text { 1st } \\
\text { Replicate } \\
\text { (mg/Kg) } \\
\end{array}$ & $\begin{array}{c}\text { 2nd } \\
\text { Replicate } \\
\text { (mg/Kg) }\end{array}$ & $\begin{array}{c}\text { 3rd } \\
\text { Replicate } \\
\text { (mg/Kg) } \\
\end{array}$ & $\begin{array}{l}\text { Average } \\
\text { (mg/Kg) }\end{array}$ & \%RSD & $\begin{array}{c}\text { Blank } \\
(\mathrm{mg} / \mathrm{Kg})\end{array}$ & $\begin{array}{c}\text { Avg Analyzed } \\
\text { Glass Std } \\
\text { (mg/Kg) } \\
\end{array}$ & \begin{tabular}{|c|}
$\begin{array}{c}\text { Glass Std } \\
\text { Composition } \\
\text { (mg/Kg) }\end{array}$ \\
\end{tabular} & $\begin{array}{c}\text { Data } \\
\text { Quality } \\
\text { Flags } \\
\end{array}$ \\
\hline $\mathrm{Ni}$ (IE) & $<3.9 \mathrm{E}+02$ & $<3.9 \mathrm{E}+02$ & $<3.9 \mathrm{E}+02$ & $<3.9 \mathrm{E}+02$ & - & $<3.9 \mathrm{E}+02$ & $8.71 E+03$ & $8.27 \mathrm{E}+03$ & - \\
\hline $\mathrm{P}$ (IE) & $<2.6 \mathrm{E}+03$ & $<2.6 \mathrm{E}+03$ & $<2.6 \mathrm{E}+03$ & $<2.6 \mathrm{E}+03$ & - & $<2.6 \mathrm{E}+03$ & $<2.6 \mathrm{E}+03$ & $1.10 \mathrm{E}+03$ & $\mathrm{U}_{\mathrm{G}}$ \\
\hline $\mathrm{Pb}$ (IE) & $<7.5 \mathrm{E}+03$ & $<7.4 \mathrm{E}+03$ & $<7.5 \mathrm{E}+03$ & $<7.4 \mathrm{E}+03$ & - & $<7.5 \mathrm{E}+03$ & $<7.5 \mathrm{E}+03$ & - & - \\
\hline$S$ (IE) & $1.87 \mathrm{E}+05$ & $1.93 E+05$ & $1.91 \mathrm{E}+05$ & $1.90 \mathrm{E}+05$ & $1.6 \%$ & $<8.5 \mathrm{E}+02$ & $<8.5 \mathrm{E}+02$ & - & - \\
\hline $\mathrm{Sb}(\mathrm{IE})$ & $1.30 \mathrm{E}+03$ & $1.51 \mathrm{E}+03$ & $<1.1 \mathrm{E}+03$ & $1.41 \mathrm{E}+03^{* *}$ & $11 \%$ & $1.40 \mathrm{E}+03$ & $1.54 \mathrm{E}+03$ & - & $\mathrm{U}_{\mathrm{E}} \mathrm{U}_{\mathrm{B}}$ \\
\hline Si (IE) & $<4.8 \mathrm{E}+03$ & $<4.7 \mathrm{E}+03$ & $<4.8 \mathrm{E}+03$ & $<4.8 \mathrm{E}+03$ & - & $<4.8 \mathrm{E}+03$ & $2.42 \mathrm{E}+05$ & $2.24 \mathrm{E}+05$ & - \\
\hline Sn (IE) & $4.39 \mathrm{E}+03$ & $5.03 \mathrm{E}+03$ & $5.27 \mathrm{E}+03$ & $4.90 \mathrm{E}+03$ & $9.3 \%$ & $5.34 \mathrm{E}+03$ & $5.47 \mathrm{E}+03$ & - & $\mathrm{U}_{\mathrm{E}} \mathrm{U}_{\mathrm{B}}$ \\
\hline Sr (IE) & $9.27 \mathrm{E}+02$ & $1.10 \mathrm{E}+03$ & $8.43 E+02$ & $9.57 \mathrm{E}+02$ & $14 \%$ & $7.59 \mathrm{E}+02$ & $2.76 \mathrm{E}+03$ & $3.00 \mathrm{E}+01$ & $\mathrm{U}_{\mathrm{G}} \mathrm{U}_{\mathrm{B}}$ \\
\hline Ti (IE) & $<3.0 \mathrm{E}+01$ & $<2.9 \mathrm{E}+01$ & $<2.9 \mathrm{E}+01$ & $<2.9 \mathrm{E}+01$ & - & $<3.0 \mathrm{E}+01$ & $6.96 \mathrm{E}+03$ & $6.90 \mathrm{E}+03$ & - \\
\hline U (IE) & $8.88 \mathrm{E}+03$ & $1.15 \mathrm{E}+04$ & $7.85 E+03$ & $9.41 \mathrm{E}+03$ & $20 \%$ & $6.90 \mathrm{E}+03$ & $5.35 \mathrm{E}+03$ & - & $\mathrm{U}_{\mathrm{R}} \mathrm{U}_{\mathrm{E}} \mathrm{U}_{\mathrm{B}}$ \\
\hline $\mathrm{Zn}$ (IE) & $2.63 \mathrm{E}+02$ & $2.83 \mathrm{E}+02$ & $2.20 \mathrm{E}+02$ & $2.55 \mathrm{E}+02$ & $13 \%$ & $2.19 \mathrm{E}+02$ & $4.00 \mathrm{E}+02$ & $1.60 \mathrm{E}+02$ & $\mathrm{U}_{\mathrm{G}} \mathrm{U}_{\mathrm{E}} \mathrm{U}_{\mathrm{B}}$ \\
\hline $\mathrm{Zr}$ (IE) & $2.33 \mathrm{E}+05$ & $2.20 \mathrm{E}+05$ & $2.24 \mathrm{E}+05$ & $2.26 \mathrm{E}+05$ & $3.0 \%$ & $2.21 \mathrm{E}+05$ & $1.51 \mathrm{E}+05$ & $9.60 \mathrm{E}+02$ & $\mathrm{U}_{\mathrm{G}} \mathrm{U}_{\mathrm{B}}$ \\
\hline
\end{tabular}

\section{* Single Value $\quad$ ** Average of two replicates}

Data Quality Flags:
$\mathrm{U}_{\mathrm{E}}$ - result is less than $10 \mathrm{X}$ the detection limit

$\mathrm{U}_{\mathrm{B}}$ - blank result greater than $5 \%$ of sample result
Divide $\mathrm{mg} / \mathrm{Kg}$ values by $1 \mathrm{E}+04$ to convert to $\mathrm{wt} \%$ basis $\mathrm{U}_{\mathrm{R}}-\% \mathrm{RSD}$ greater than $15 \%$

$\mathrm{U}_{\mathrm{G}}-$ glass std result greater than $15 \%$ from expected result 
Table 3-8. Composition of the Water Contact of Solids from Tank 4F Sample FTF-434

\begin{tabular}{|c|c|c|c|c|c|c|}
\hline Analyte & $\begin{array}{c}\text { 1st } \\
\text { Replicate } \\
\text { (mg/Kg) }\end{array}$ & $\begin{array}{c}\text { 2nd } \\
\text { Replicate } \\
\text { (mg/Kg) }\end{array}$ & $\begin{array}{c}\text { 3rd } \\
\text { Replicate } \\
\text { (mg/Kg) }\end{array}$ & $\begin{array}{l}\text { Average } \\
\text { (mg/Kg) }\end{array}$ & \%RSD & $\begin{array}{c}\text { Blank } \\
\text { (mg/Kg) }\end{array}$ \\
\hline $\mathrm{NO}_{3}^{-}$(IC) & $<4.7 \mathrm{E}+04$ & $<7.3 \mathrm{E}+04$ & $<3.7 \mathrm{E}+04$ & $<5.2 \mathrm{E}+04$ & - & $<4.8 \mathrm{E}+04$ \\
\hline $\mathrm{NO}_{2}^{-}$(IC) & $<4.7 \mathrm{E}+04$ & $<7.3 \mathrm{E}+04$ & $<3.7 \mathrm{E}+04$ & $<5.2 \mathrm{E}+04$ & - & $<4.8 \mathrm{E}+04$ \\
\hline $\mathrm{PO}_{4}^{3-}$ (IC) & $<4.7 \mathrm{E}+04$ & $<7.3 \mathrm{E}+04$ & $<3.7 \mathrm{E}+04$ & $<5.2 \mathrm{E}+04$ & - & $<4.8 \mathrm{E}+04$ \\
\hline $\mathrm{SO}_{4}^{2-}(\mathrm{IC})$ & $5.36 \mathrm{E}+05$ & $4.61 \mathrm{E}+05$ & $4.86 \mathrm{E}+05$ & $4.94 \mathrm{E}+05$ & $7.7 \%$ & $<2.4 \mathrm{E}+04$ \\
\hline $\mathrm{C}_{2} \mathrm{O}_{4}{ }^{2-}$ (IC) & $<4.7 \mathrm{E}+04$ & $<7.3 \mathrm{E}+04$ & $<3.7 \mathrm{E}+04$ & $<5.2 \mathrm{E}+04$ & - & $<4.8 \mathrm{E}+04$ \\
\hline $\mathrm{Cl}^{-}(\mathrm{IC})$ & $2.44 \mathrm{E}+04$ & $<1.5 \mathrm{E}+04$ & $<7.4 \mathrm{E}+03$ & $2.44 \mathrm{E}+04^{*}$ & - & $<9.7 \mathrm{E}+03$ \\
\hline $\mathrm{F}^{-}(\mathrm{IC})$ & $<9.4 \mathrm{E}+03$ & $<1.5 \mathrm{E}+04$ & $<7.4 \mathrm{E}+03$ & $<1.0 \mathrm{E}+04$ & - & $<9.7 \mathrm{E}+03$ \\
\hline Ag (IE) & $<5.6 \mathrm{E}+00$ & $<8.8 \mathrm{E}+00$ & $<4.4 \mathrm{E}+00$ & $<6.3 \mathrm{E}+00$ & - & $<5.8 \mathrm{E}+00$ \\
\hline $\mathrm{Al}$ (IE) & $<2.2 \mathrm{E}+01$ & $<3.4 \mathrm{E}+01$ & $<1.7 \mathrm{E}+01$ & $<2.4 \mathrm{E}+01$ & - & $<2.2 \mathrm{E}+01$ \\
\hline B (IE) & $1.07 \mathrm{E}+02$ & $5.91 \mathrm{E}+01$ & $4.31 \mathrm{E}+01$ & $6.98 \mathrm{E}+01$ & $48 \%$ & $<2.8 \mathrm{E}+01$ \\
\hline Ba (IE) & $<1.2 \mathrm{E}+01$ & $<1.8 \mathrm{E}+01$ & $<9.2 \mathrm{E}+00$ & $<1.3 \mathrm{E}+01$ & - & $<1.2 \mathrm{E}+01$ \\
\hline Ca (IE) & $1.26 \mathrm{E}+03$ & $1.57 \mathrm{E}+03$ & $1.09 \mathrm{E}+03$ & $1.31 \mathrm{E}+03$ & $19 \%$ & $3.04 \mathrm{E}+02$ \\
\hline Cd (IE) & $<2.3 \mathrm{E}+00$ & $<3.6 \mathrm{E}+00$ & $<1.8 \mathrm{E}+00$ & $<2.6 \mathrm{E}+00$ & - & $<2.4 \mathrm{E}+00$ \\
\hline Ce (IE) & $7.57 \mathrm{E}+01$ & $1.09 \mathrm{E}+02$ & $9.83 \mathrm{E}+01$ & $9.45 E+01$ & $18 \%$ & $<7.2 \mathrm{E}+01$ \\
\hline Cr (IE) & $1.66 \mathrm{E}+02$ & $1.40 \mathrm{E}+02$ & $1.04 \mathrm{E}+02$ & $1.37 \mathrm{E}+02$ & $23 \%$ & $<1.4 \mathrm{E}+01$ \\
\hline $\mathrm{Cu}$ (IE) & $<5.2 \mathrm{E}+00$ & $<8.0 \mathrm{E}+00$ & $<4.1 \mathrm{E}+00$ & $<5.7 \mathrm{E}+00$ & - & $<5.3 \mathrm{E}+00$ \\
\hline Fe (IE) & $<6.1 \mathrm{E}+00$ & $<9.5 \mathrm{E}+00$ & $<4.8 \mathrm{E}+00$ & $<6.8 \mathrm{E}+00$ & - & $<6.3 \mathrm{E}+00$ \\
\hline Gd (IE) & $<8.9 \mathrm{E}+00$ & $<1.4 \mathrm{E}+01$ & $<7.0 \mathrm{E}+00$ & $<9.9 \mathrm{E}+00$ & - & $<9.2 \mathrm{E}+00$ \\
\hline K (IE) & $6.67 \mathrm{E}+02$ & $1.48 \mathrm{E}+03$ & $6.78 \mathrm{E}+02$ & $9.42 \mathrm{E}+02$ & $50 \%$ & $<4.1 \mathrm{E}+02$ \\
\hline La (IE) & $<2.7 \mathrm{E}+01$ & $<4.2 \mathrm{E}+01$ & $<2.1 \mathrm{E}+01$ & $<3.0 \mathrm{E}+01$ & - & $<2.8 \mathrm{E}+01$ \\
\hline Li (IE) & $<2.5 \mathrm{E}+01$ & $<3.9 \mathrm{E}+01$ & $<2.0 \mathrm{E}+01$ & $<2.8 \mathrm{E}+01$ & - & $<2.6 \mathrm{E}+01$ \\
\hline Mg (IE) & $2.97 \mathrm{E}+02$ & $3.52 E+02$ & $2.43 \mathrm{E}+02$ & $2.97 \mathrm{E}+02$ & $18 \%$ & $8.90 \mathrm{E}+01$ \\
\hline Mn (IE) & $<9.4 \mathrm{E}-01$ & $<1.5 \mathrm{E}+00$ & $<7.4 \mathrm{E}-01$ & $<1.0 \mathrm{E}+00$ & - & $<9.7 \mathrm{E}-01$ \\
\hline Mo (IE) & $<6.9 \mathrm{E}+01$ & $<1.1 \mathrm{E}+02$ & $<5.4 \mathrm{E}+01$ & $<7.6 \mathrm{E}+01$ & - & $<7.1 \mathrm{E}+01$ \\
\hline $\mathrm{Na}$ (IE) & $3.42 \mathrm{E}+05$ & $3.57 \mathrm{E}+05$ & $3.55 \mathrm{E}+05$ & $3.51 \mathrm{E}+05$ & $2.4 \%$ & $5.61 \mathrm{E}+02$ \\
\hline
\end{tabular}


WSRC-TR-2005-00441, REV. 0

Table 3-8. Composition of the Water Contact of Solids from Tank 4F Sample FTF-434 (continued)

\begin{tabular}{|c|c|c|c|c|c|c|}
\hline Analyte & $\begin{array}{c}\text { 1st } \\
\text { Replicate } \\
\text { (mg/Kg) }\end{array}$ & $\begin{array}{c}\text { 2nd } \\
\text { Replicate } \\
\text { (mg/Kg) }\end{array}$ & $\begin{array}{c}\text { 3rd } \\
\text { Replicate } \\
\text { (mg/Kg) }\end{array}$ & $\begin{array}{l}\text { Average } \\
\text { (mg/Kg) }\end{array}$ & \%RSD & $\begin{array}{c}\text { Blank } \\
\text { (mg/Kg) }\end{array}$ \\
\hline $\mathrm{Ni}$ (IE) & $<2.1 \mathrm{E}+01$ & $<3.2 \mathrm{E}+01$ & $<1.6 \mathrm{E}+01$ & $<2.3 \mathrm{E}+01$ & - & $<2.1 \mathrm{E}+01$ \\
\hline $\mathrm{P}$ (IE) & $3.60 \mathrm{E}+02$ & $3.41 \mathrm{E}+02$ & $2.94 \mathrm{E}+02$ & $3.32 \mathrm{E}+02$ & $10 \%$ & $<1.4 \mathrm{E}+02$ \\
\hline $\mathrm{Pb}$ (IE) & $<3.9 \mathrm{E}+02$ & $<6.1 \mathrm{E}+02$ & $<3.1 \mathrm{E}+02$ & $<4.4 \mathrm{E}+02$ & - & $<4.0 \mathrm{E}+02$ \\
\hline$S$ (IE) & $1.58 \mathrm{E}+05$ & $1.60 \mathrm{E}+05$ & $1.73 \mathrm{E}+05$ & $1.64 \mathrm{E}+05$ & $4.8 \%$ & $1.78 \mathrm{E}+02$ \\
\hline Sb (IE) & $<6.0 \mathrm{E}+01$ & $<9.3 \mathrm{E}+01$ & $<4.7 \mathrm{E}+01$ & $<6.7 \mathrm{E}+01$ & - & $<6.2 \mathrm{E}+01$ \\
\hline Si (IE) & $6.58 \mathrm{E}+02$ & $4.65 \mathrm{E}+02$ & $3.11 \mathrm{E}+02$ & $4.78 \mathrm{E}+02$ & $36 \%$ & $<2.6 \mathrm{E}+02$ \\
\hline Sn (IE) & $<1.6 \mathrm{E}+02$ & $<2.4 \mathrm{E}+02$ & $<1.2 \mathrm{E}+02$ & $<1.7 \mathrm{E}+02$ & - & $<1.6 \mathrm{E}+02$ \\
\hline Sr (IE) & $2.51 \mathrm{E}+02$ & $3.07 \mathrm{E}+02$ & $2.17 \mathrm{E}+02$ & $2.58 \mathrm{E}+02$ & $18 \%$ & $4.98 \mathrm{E}+01$ \\
\hline Ti (IE) & $<1.4 \mathrm{E}+00$ & $<2.2 \mathrm{E}+00$ & $<1.1 \mathrm{E}+00$ & $<1.6 \mathrm{E}+00$ & - & $<1.5 \mathrm{E}+00$ \\
\hline U (IE) & $<1.0 \mathrm{E}+02$ & $<1.6 \mathrm{E}+02$ & $<8.0 \mathrm{E}+01$ & $<1.1 \mathrm{E}+02$ & - & $<1.0 \mathrm{E}+02$ \\
\hline V (IE) & $9.59 \mathrm{E}+01$ & $<1.6 \mathrm{E}+01$ & $2.39 \mathrm{E}+01$ & $5.99 \mathrm{E}+01^{* *}$ & $73 \%$ & $<1.1 \mathrm{E}+01$ \\
\hline Zn (IE) & $<3.8 \mathrm{E}+00$ & $<5.8 \mathrm{E}+00$ & $<2.9 \mathrm{E}+00$ & $<4.2 \mathrm{E}+00$ & - & $<3.9 \mathrm{E}+00$ \\
\hline $\mathrm{Zr}$ (IE) & $<4.2 \mathrm{E}+00$ & $<6.6 \mathrm{E}+00$ & $<3.3 \mathrm{E}+00$ & $<4.7 \mathrm{E}+00$ & - & $<4.4 \mathrm{E}+00$ \\
\hline
\end{tabular}


Table 3-9. Composition of the Water Contact of Solids from Tank 4F Sample FTF-435

\begin{tabular}{|c|c|c|c|c|c|c|}
\hline Analyte & $\begin{array}{c}\text { 1st } \\
\text { Replicate } \\
\text { (mg/Kg) }\end{array}$ & $\begin{array}{c}\text { 2nd } \\
\text { Replicate } \\
\text { (mg/Kg) }\end{array}$ & $\begin{array}{c}\text { 3rd } \\
\text { Replicate } \\
\text { (mg/Kg) }\end{array}$ & $\begin{array}{l}\text { Average } \\
\text { (mg/Kg) }\end{array}$ & \%RSD & $\begin{array}{c}\text { Blank } \\
\text { (mg/Kg) }\end{array}$ \\
\hline $\mathrm{NO}_{3}^{-}$(IC) & $3.84 \mathrm{E}+04$ & $<4.3 \mathrm{E}+04$ & $<4.3 \mathrm{E}+04$ & $3.84 \mathrm{E}+04 *$ & - & $<3.8 \mathrm{E}+04$ \\
\hline $\mathrm{NO}_{2}^{-}$(IC) & $3.27 \mathrm{E}+04$ & $<4.3 \mathrm{E}+04$ & $<4.3 \mathrm{E}+04$ & $3.27 \mathrm{E}+04^{*}$ & - & $<3.8 \mathrm{E}+04$ \\
\hline $\mathrm{PO}_{4}^{3-}$ (IC) & $<3.2 \mathrm{E}+04$ & $<4.3 \mathrm{E}+04$ & $<4.3 \mathrm{E}+04$ & $<3.9 \mathrm{E}+04$ & - & $<3.8 \mathrm{E}+04$ \\
\hline $\mathrm{SO}_{4}^{2-}$ (IC) & $3.72 \mathrm{E}+05$ & $4.92 \mathrm{E}+05$ & $4.88 \mathrm{E}+05$ & $4.51 \mathrm{E}+05$ & $15 \%$ & $<1.9 \mathrm{E}+04$ \\
\hline $\mathrm{C}_{2} \mathrm{O}_{4}{ }^{2-}$ (IC) & $<3.2 \mathrm{E}+04$ & $<4.3 \mathrm{E}+04$ & $<4.3 \mathrm{E}+04$ & $<3.9 \mathrm{E}+04$ & - & $<3.8 \mathrm{E}+04$ \\
\hline $\mathrm{Cl}^{-}(\mathrm{IC})$ & $<6.4 \mathrm{E}+03$ & $<8.6 \mathrm{E}+03$ & $<8.6 \mathrm{E}+03$ & $<7.8 \mathrm{E}+03$ & - & $<7.7 \mathrm{E}+03$ \\
\hline $\mathrm{F}^{-}(\mathrm{IC})$ & $<6.4 \mathrm{E}+03$ & $<8.6 \mathrm{E}+03$ & $<8.6 \mathrm{E}+03$ & $<7.8 \mathrm{E}+03$ & - & $<7.7 \mathrm{E}+03$ \\
\hline Ag (IE) & $<3.8 \mathrm{E}+00$ & $<5.2 \mathrm{E}+00$ & $<5.1 \mathrm{E}+00$ & $<4.7 \mathrm{E}+00$ & - & $<4.6 \mathrm{E}+00$ \\
\hline $\mathrm{Al}(\mathrm{IE})$ & $1.18 \mathrm{E}+03$ & $2.57 \mathrm{E}+02$ & $4.50 \mathrm{E}+02$ & $6.29 \mathrm{E}+02$ & $77 \%$ & $<1.8 \mathrm{E}+01$ \\
\hline B (IE) & $<1.8 \mathrm{E}+01$ & $<2.5 \mathrm{E}+01$ & $<2.5 \mathrm{E}+01$ & $<2.3 \mathrm{E}+01$ & - & $<2.2 \mathrm{E}+01$ \\
\hline Ba (IE) & $<7.9 \mathrm{E}+00$ & $<1.1 \mathrm{E}+01$ & $<1.1 \mathrm{E}+01$ & $<9.8 \mathrm{E}+00$ & - & $<9.6 \mathrm{E}+00$ \\
\hline Ca (IE) & $8.51 E+02$ & $8.32 \mathrm{E}+02$ & $9.94 \mathrm{E}+02$ & $8.92 E+02$ & $10 \%$ & $2.54 \mathrm{E}+02$ \\
\hline Cd (IE) & $<1.6 \mathrm{E}+00$ & $<2.2 \mathrm{E}+00$ & $<2.1 \mathrm{E}+00$ & $<2.0 \mathrm{E}+00$ & - & $<1.9 \mathrm{E}+00$ \\
\hline Ce (IE) & $1.31 \mathrm{E}+02$ & $1.94 \mathrm{E}+02$ & $1.79 \mathrm{E}+02$ & $1.68 \mathrm{E}+02$ & $19 \%$ & $<5.7 \mathrm{E}+01$ \\
\hline Cr (IE) & $3.24 \mathrm{E}+02$ & $9.66 \mathrm{E}+01$ & $1.51 \mathrm{E}+02$ & $1.91 \mathrm{E}+02$ & $62 \%$ & $<1.1 \mathrm{E}+01$ \\
\hline $\mathrm{Cu}$ (IE) & $<3.5 \mathrm{E}+00$ & $<4.7 \mathrm{E}+00$ & $<4.7 \mathrm{E}+00$ & $<4.3 \mathrm{E}+00$ & - & $<4.2 \mathrm{E}+00$ \\
\hline Fe (IE) & $<4.1 \mathrm{E}+00$ & $<5.6 \mathrm{E}+00$ & $<5.6 \mathrm{E}+00$ & $<5.1 \mathrm{E}+00$ & - & $<5.0 \mathrm{E}+00$ \\
\hline Gd (IE) & $<6.0 \mathrm{E}+00$ & $1.04 \mathrm{E}+01$ & $1.03 \mathrm{E}+01$ & $1.03 \mathrm{E}+01^{* *}$ & $0.5 \%$ & $<7.3 \mathrm{E}+00$ \\
\hline K (IE) & $7.14 \mathrm{E}+02$ & $5.13 \mathrm{E}+02$ & $1.39 \mathrm{E}+03$ & $8.72 \mathrm{E}+02$ & $53 \%$ & $<3.3 \mathrm{E}+02$ \\
\hline La (IE) & $<1.8 \mathrm{E}+01$ & $2.50 \mathrm{E}+01$ & $<2.4 \mathrm{E}+01$ & $2.50 \mathrm{E}+01^{*}$ & - & $<2.2 \mathrm{E}+01$ \\
\hline Li (IE) & $<1.7 \mathrm{E}+01$ & $2.50 \mathrm{E}+01$ & $2.40 \mathrm{E}+01$ & $2.45 \mathrm{E}+01^{* *}$ & $3.0 \%$ & $<2.0 \mathrm{E}+01$ \\
\hline Mg (IE) & $8.22 \mathrm{E}+01$ & $1.25 \mathrm{E}+02$ & $1.56 \mathrm{E}+02$ & $1.21 \mathrm{E}+02$ & $31 \%$ & $7.54 \mathrm{E}+01$ \\
\hline Mn (IE) & $<6.4 \mathrm{E}-01$ & $<8.6 \mathrm{E}-01$ & $<8.6 \mathrm{E}-01$ & $<7.8 \mathrm{E}-01$ & - & $<7.7 \mathrm{E}-01$ \\
\hline Mo (IE) & $7.84 \mathrm{E}+01$ & $<6.3 \mathrm{E}+01$ & $<6.3 \mathrm{E}+01$ & $7.84 \mathrm{E}+01^{*}$ & - & $<5.6 \mathrm{E}+01$ \\
\hline $\mathrm{Na}$ (IE) & $2.94 \mathrm{E}+05$ & $3.47 \mathrm{E}+05$ & $3.33 \mathrm{E}+05$ & $3.25 E+05$ & $8.5 \%$ & $2.47 \mathrm{E}+02$ \\
\hline
\end{tabular}


WSRC-TR-2005-00441, REV. 0

Table 3-9. Composition of the Water Contact of Solids from Tank 4F Sample FTF-435 (continued)

\begin{tabular}{|c|c|c|c|c|c|c|}
\hline Analyte & $\begin{array}{c}\text { 1st } \\
\text { Replicate } \\
\text { (mg/Kg) }\end{array}$ & $\begin{array}{c}\text { 2nd } \\
\text { Replicate } \\
\text { (mg/Kg) }\end{array}$ & $\begin{array}{c}\text { 3rd } \\
\text { Replicate } \\
\text { (mg/Kg) }\end{array}$ & $\begin{array}{l}\text { Average } \\
\text { (mg/Kg) }\end{array}$ & \%RSD & $\begin{array}{c}\text { Blank } \\
\text { (mg/Kg) }\end{array}$ \\
\hline $\mathrm{Ni}$ (IE) & $<1.4 \mathrm{E}+01$ & $<1.9 \mathrm{E}+01$ & $<1.9 \mathrm{E}+01$ & $<1.7 \mathrm{E}+01$ & - & $<1.7 \mathrm{E}+01$ \\
\hline $\mathrm{P}$ (IE) & $3.49 E+02$ & $2.66 \mathrm{E}+02$ & $3.36 \mathrm{E}+02$ & $3.17 \mathrm{E}+02$ & $14 \%$ & $<1.1 \mathrm{E}+02$ \\
\hline $\mathrm{Pb}$ (IE) & $<2.7 \mathrm{E}+02$ & $<3.6 \mathrm{E}+02$ & $<3.6 \mathrm{E}+02$ & $<3.3 \mathrm{E}+02$ & - & $<3.2 \mathrm{E}+02$ \\
\hline S (IE) & $1.27 \mathrm{E}+05$ & $1.57 \mathrm{E}+05$ & $1.46 \mathrm{E}+05$ & $1.43 \mathrm{E}+05$ & $11 \%$ & $6.54 \mathrm{E}+01$ \\
\hline Sb (IE) & $<4.1 \mathrm{E}+01$ & $<5.5 \mathrm{E}+01$ & $<5.5 \mathrm{E}+01$ & $<5.0 \mathrm{E}+01$ & - & $<4.9 \mathrm{E}+01$ \\
\hline Si (IE) & $<1.7 \mathrm{E}+02$ & $<2.3 \mathrm{E}+02$ & $<2.3 \mathrm{E}+02$ & $<2.1 \mathrm{E}+02$ & - & $<2.1 \mathrm{E}+02$ \\
\hline Sn (IE) & $<1.0 \mathrm{E}+02$ & $<1.4 \mathrm{E}+02$ & $<1.4 \mathrm{E}+02$ & $<1.3 \mathrm{E}+02$ & - & $<1.3 \mathrm{E}+02$ \\
\hline Sr (IE) & $1.76 \mathrm{E}+02$ & $1.77 \mathrm{E}+02$ & $2.06 \mathrm{E}+02$ & $1.87 \mathrm{E}+02$ & $9.3 \%$ & $4.42 \mathrm{E}+01$ \\
\hline Ti (IE) & $<9.5 \mathrm{E}-01$ & $<1.3 \mathrm{E}+00$ & $<1.3 \mathrm{E}+00$ & $<1.2 \mathrm{E}+00$ & - & $<1.2 \mathrm{E}+00$ \\
\hline U (IE) & $8.67 \mathrm{E}+01$ & $1.00 \mathrm{E}+02$ & $<9.3 \mathrm{E}+01$ & $9.36 \mathrm{E}+01^{* *}$ & $10 \%$ & $<8.3 \mathrm{E}+01$ \\
\hline V (IE) & $6.70 \mathrm{E}+01$ & $<9.5 \mathrm{E}+00$ & $<9.4 \mathrm{E}+00$ & $6.70 \mathrm{E}+01 *$ & - & $<8.5 \mathrm{E}+00$ \\
\hline Zn (IE) & $<2.5 \mathrm{E}+00$ & $<3.5 \mathrm{E}+00$ & $<3.4 \mathrm{E}+00$ & $<3.1 \mathrm{E}+00$ & - & $<3.1 \mathrm{E}+00$ \\
\hline $\mathrm{Zr}$ (IE) & $<2.9 \mathrm{E}+00$ & $<3.9 \mathrm{E}+00$ & $<3.9 \mathrm{E}+00$ & $<3.5 \mathrm{E}+00$ & - & $<3.5 \mathrm{E}+00$ \\
\hline
\end{tabular}




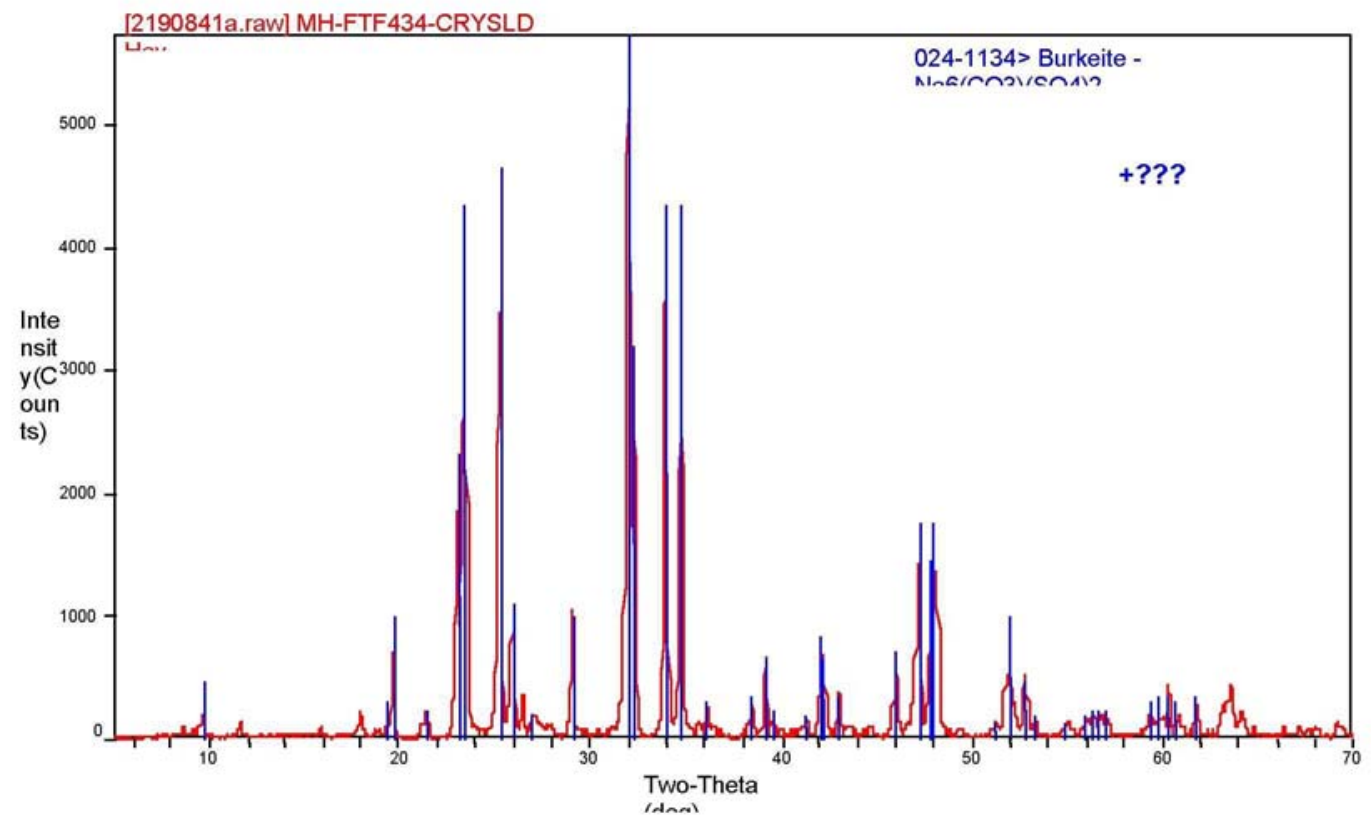

Figure 3.1 X-Ray Diffraction for Solids from Tank 4F Sample FTF-434

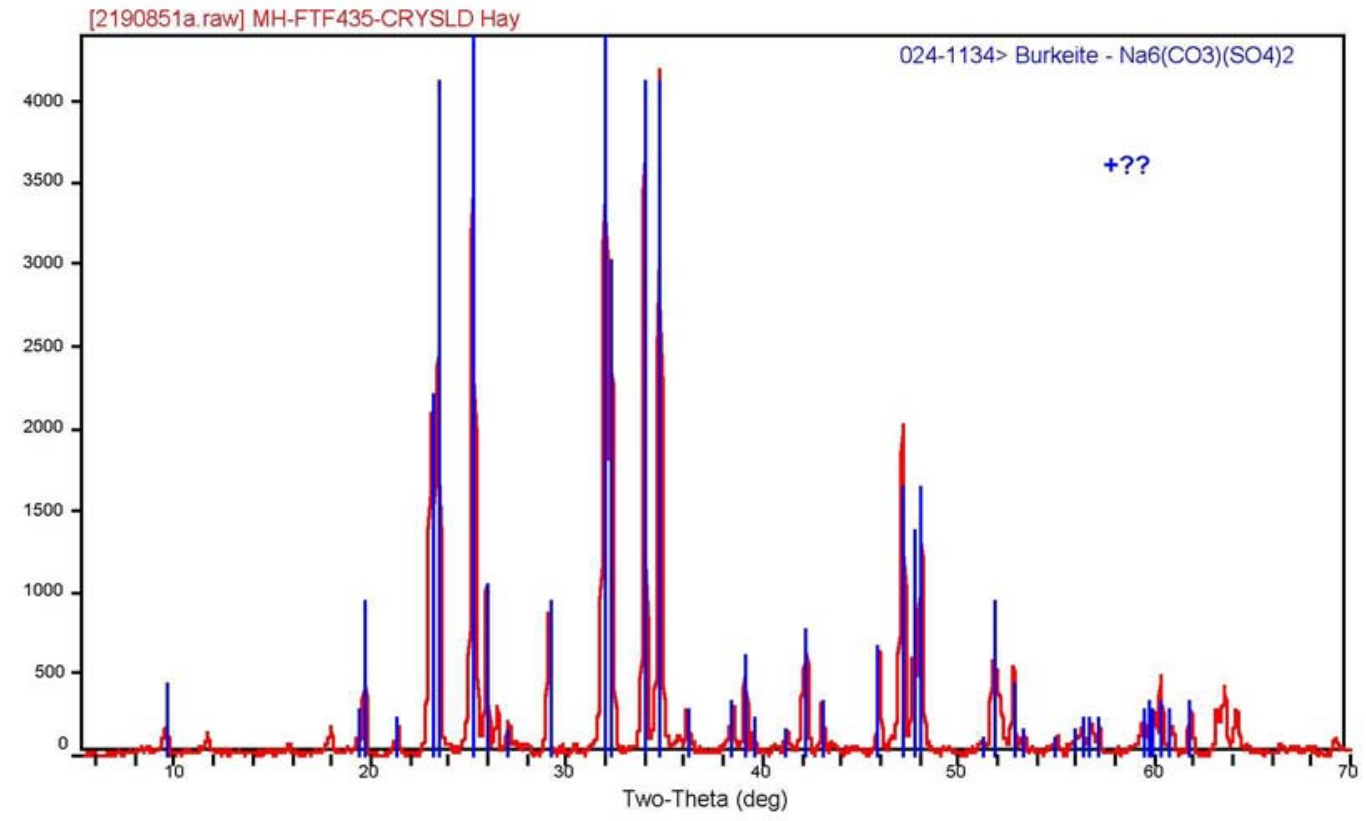

Figure 3.2 X-Ray Diffraction for Solids from Tank 4F Sample FTF-435 


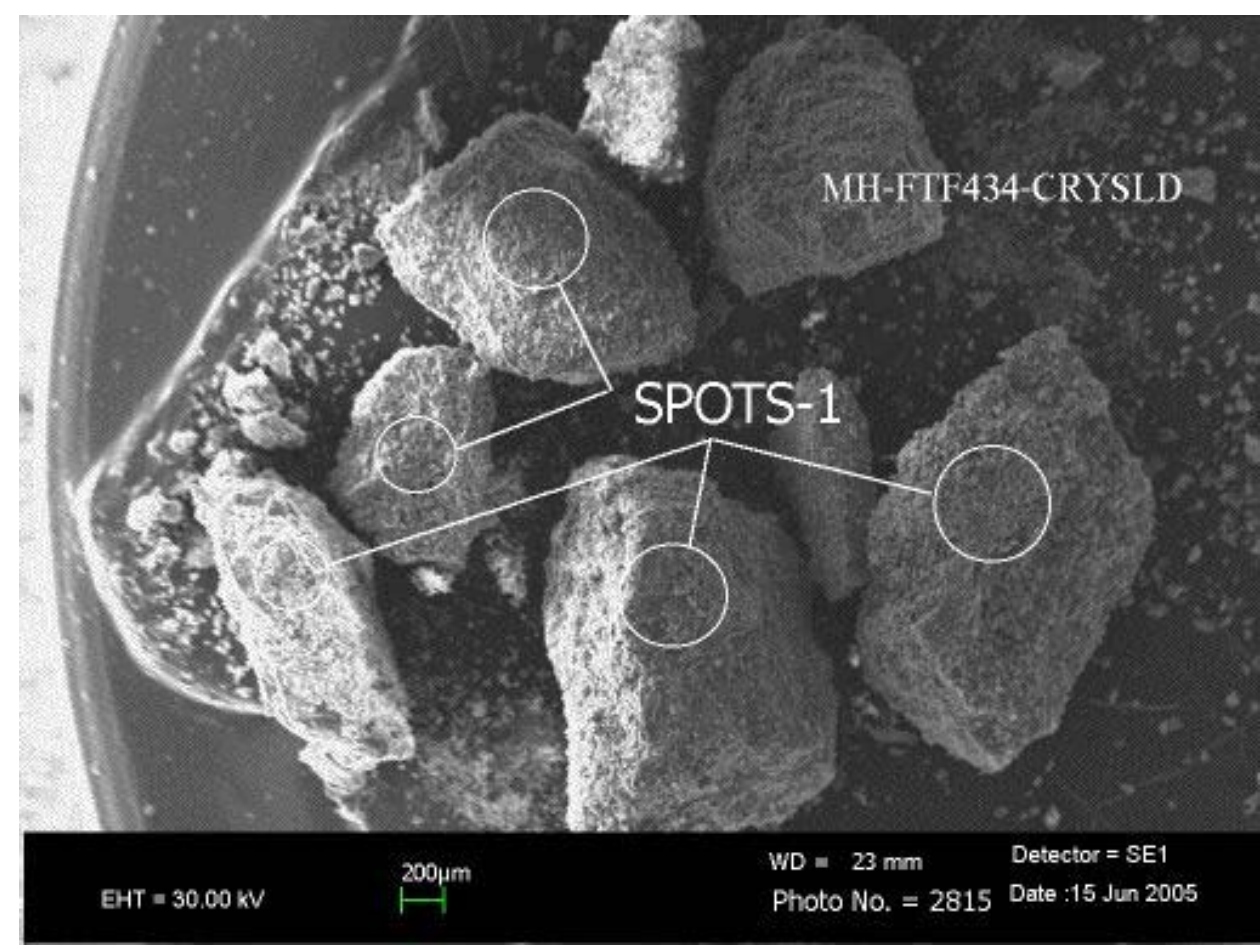

Figure 3.3 SEM Micrograph of Solids from Tank 4F Sample FTF-434 (20X Magnification)

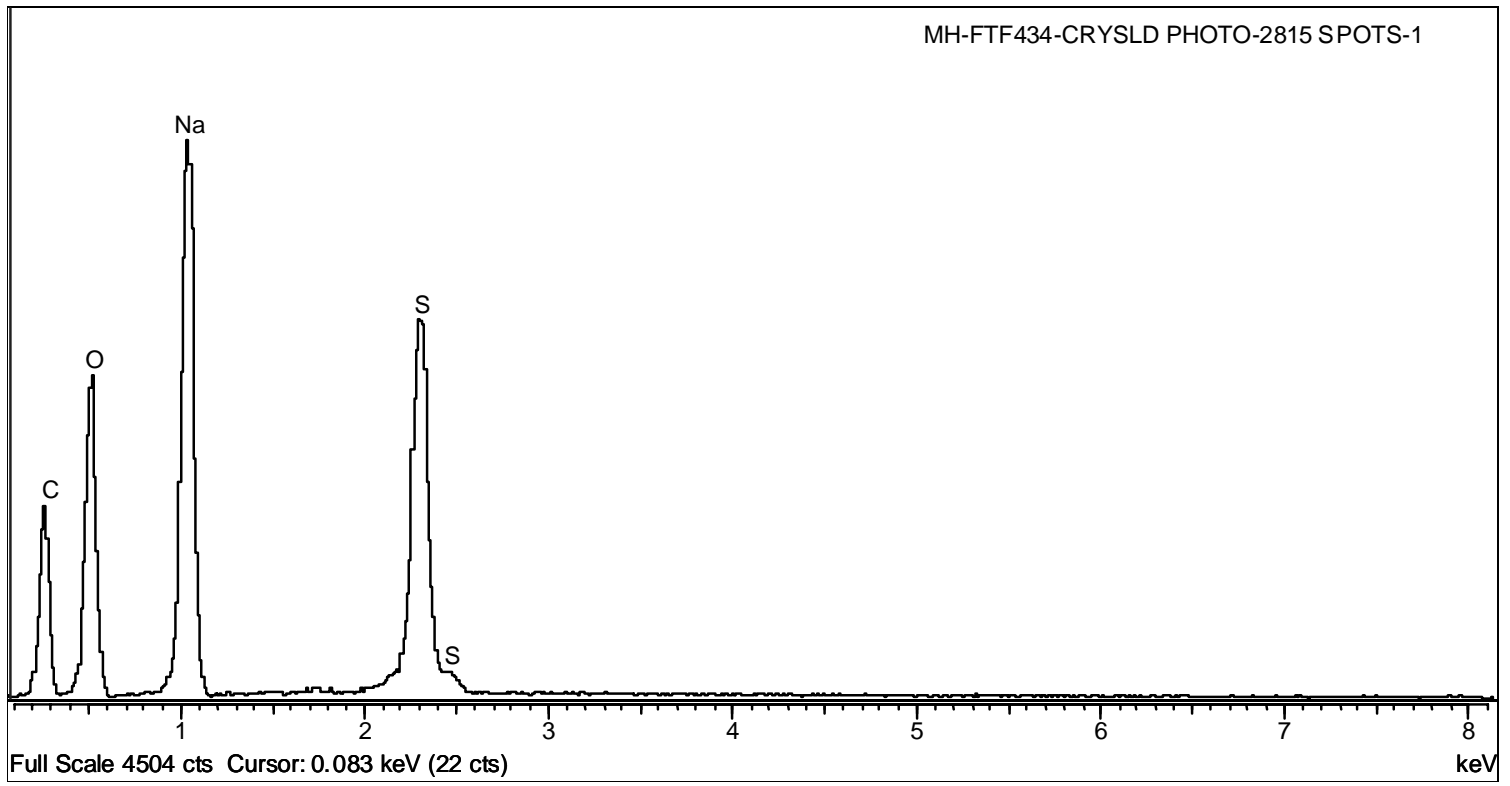

Figure 3.4 Spectrum of Spot 1 from Figure 3.3 


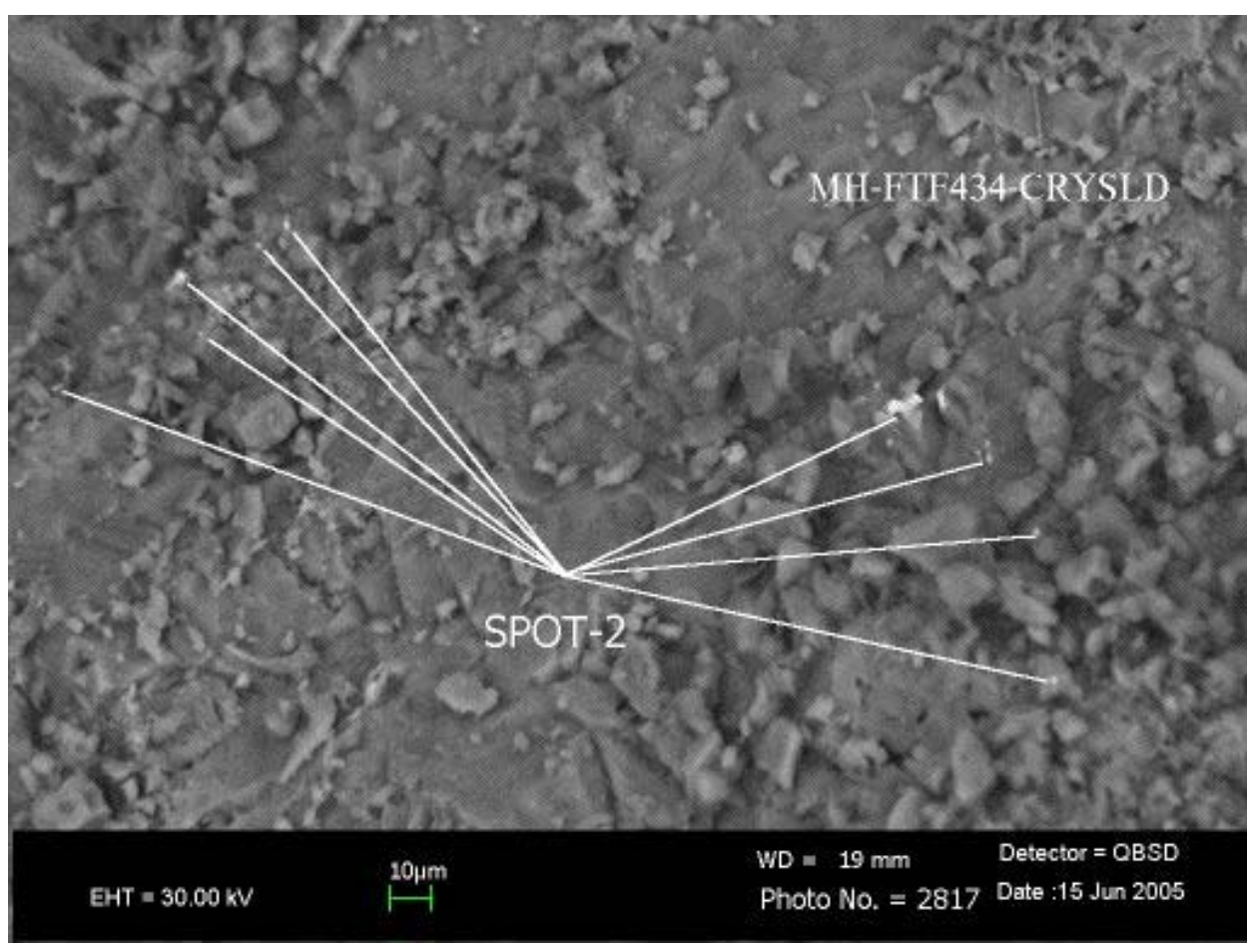

Figure 3.5 SEM Micrograph of Solids from Tank 4F Sample FTF-434 (375X Magnification)

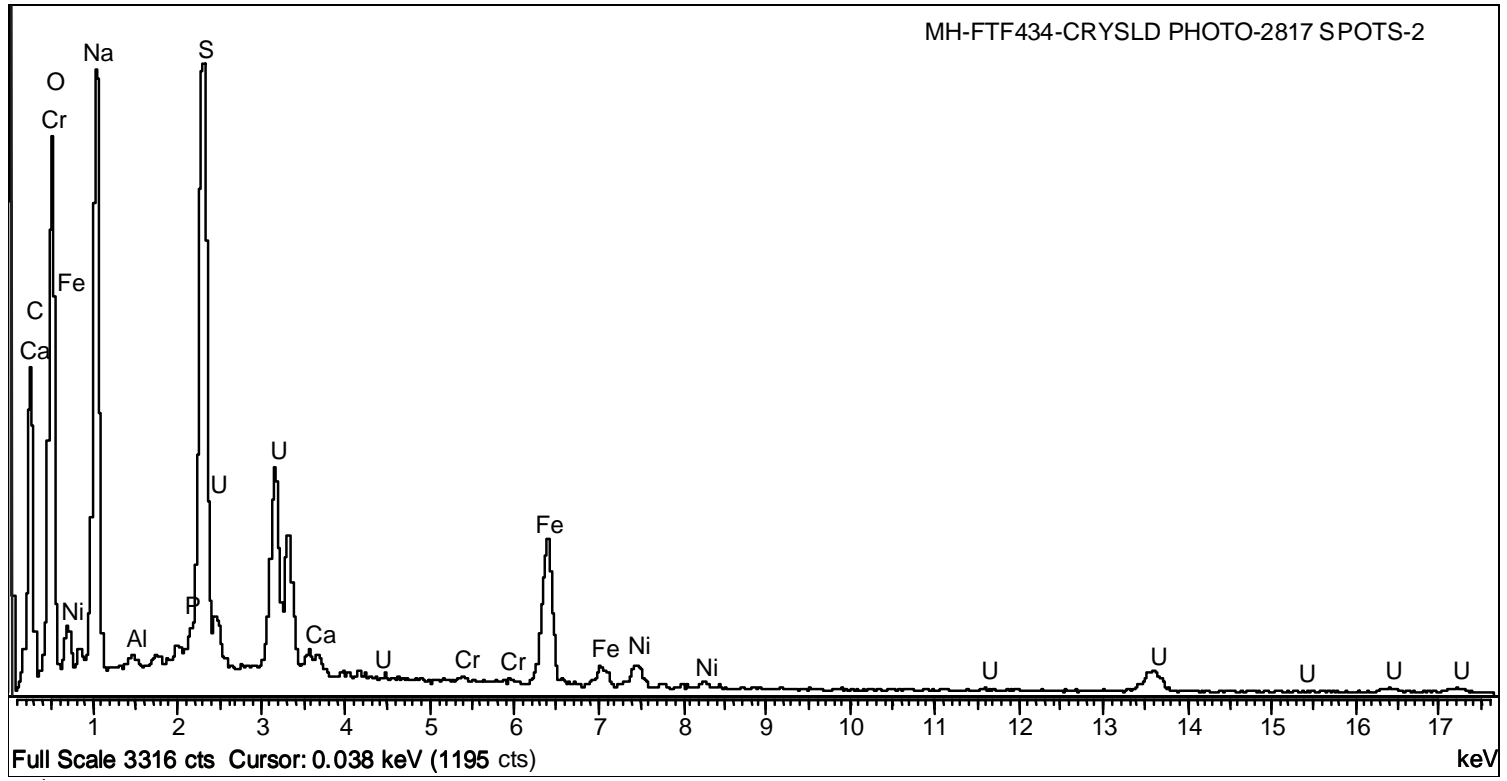

Figure 3.6 Spectrum of Spot 2 from Figure 3.5 


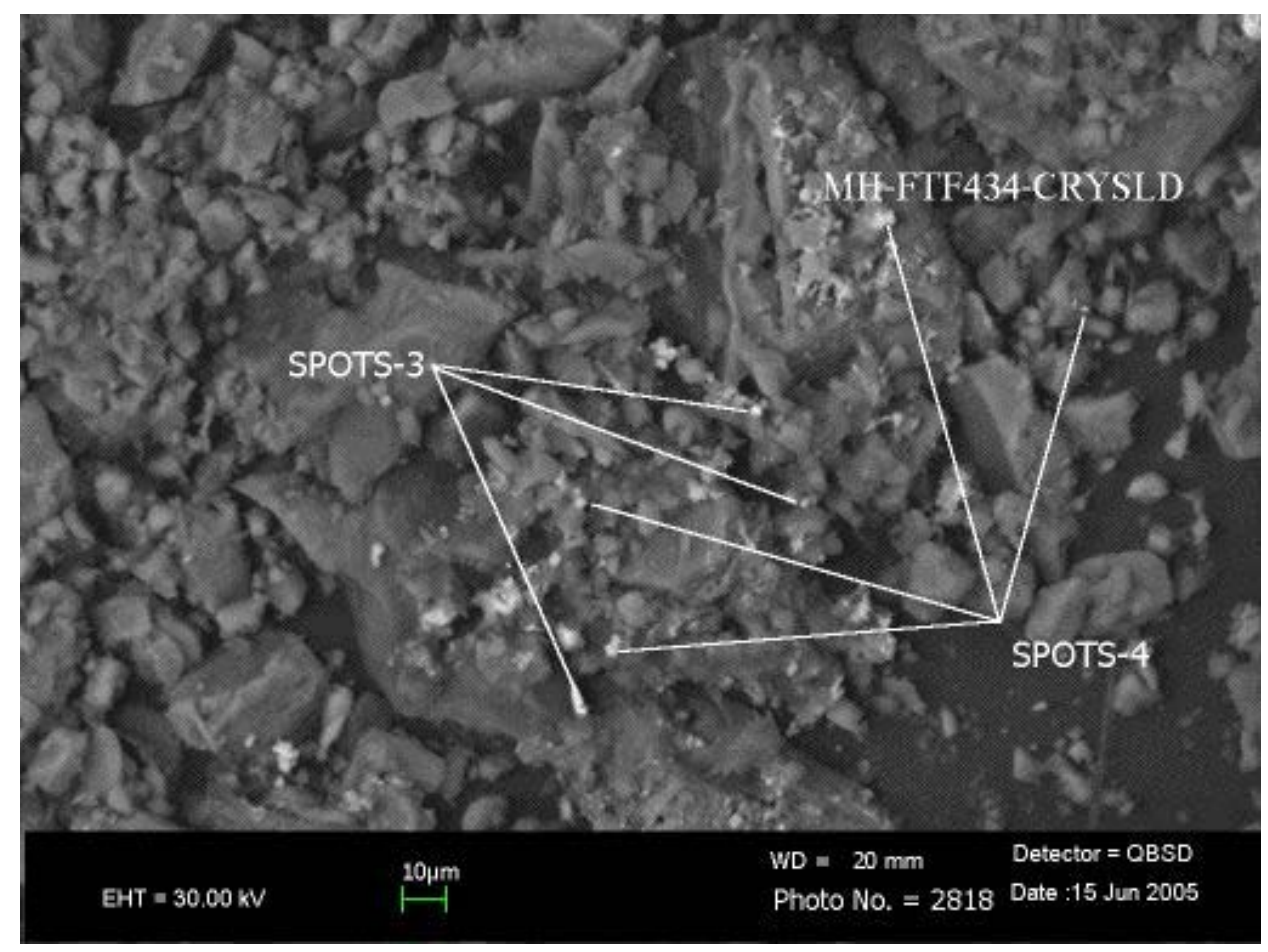

Figure 3.7 SEM Micrograph of Solids from Tank 4F Sample FTF-434 (400X Magnification)

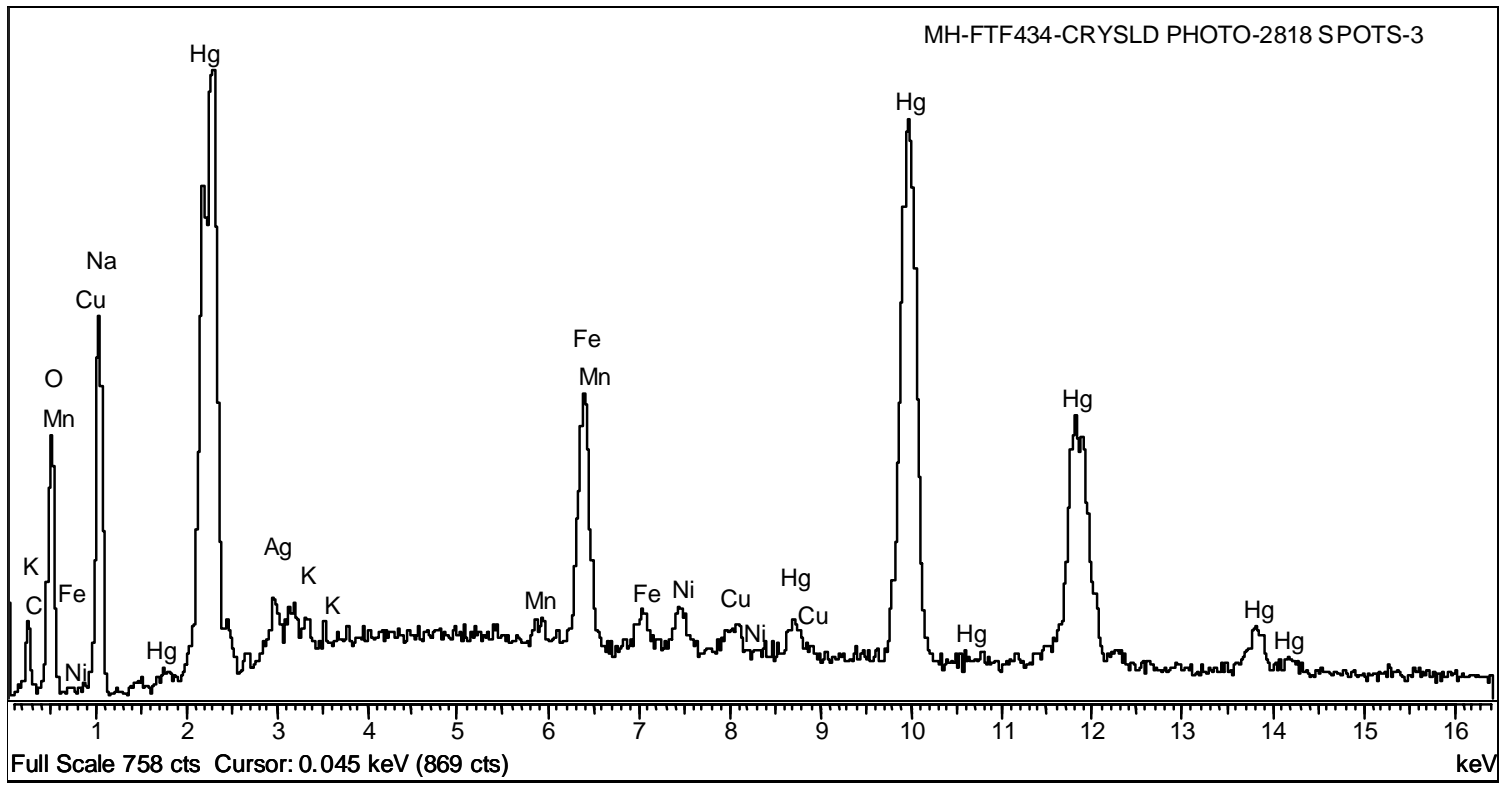

Figure 3.8 Spectrum of Spot 3 from Figure 3.7 
WSRC-TR-2005-00441, REV. 0

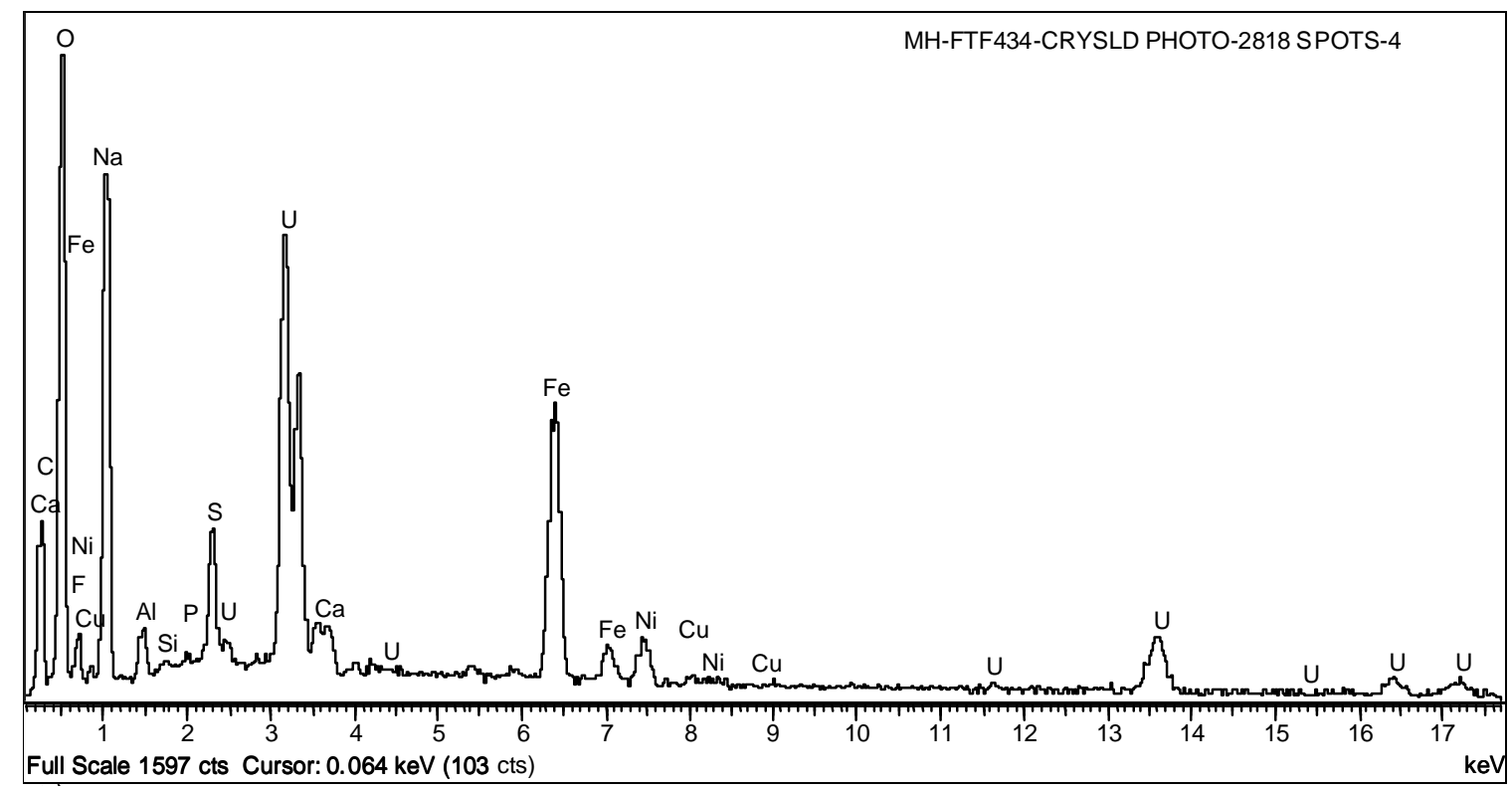

Figure 3.9 Spectrum of Spot 4 from Figure 3.7 


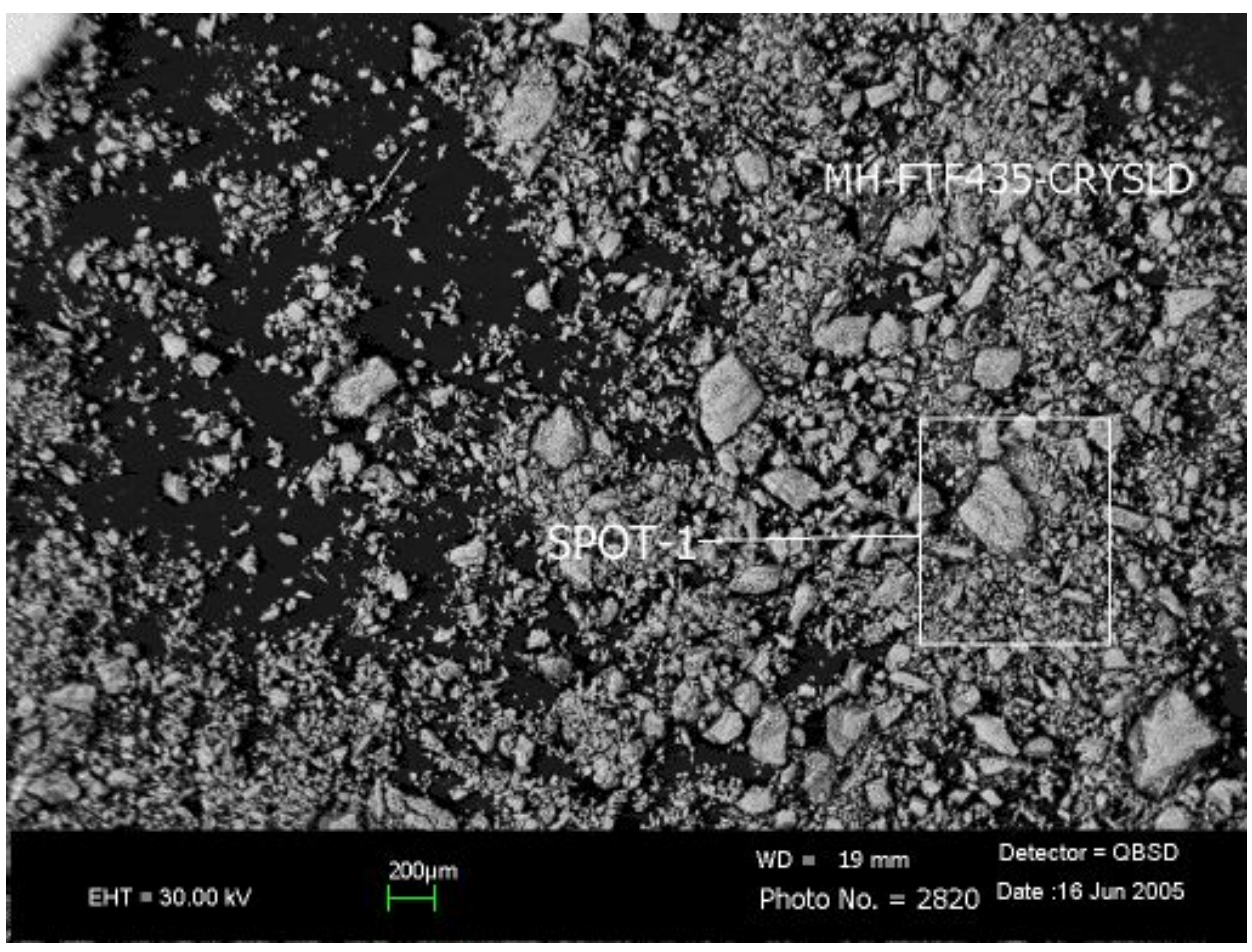

Figure 3.10 SEM Micrograph of Solids from Tank 4F Sample FTF-435 (21X Magnification)

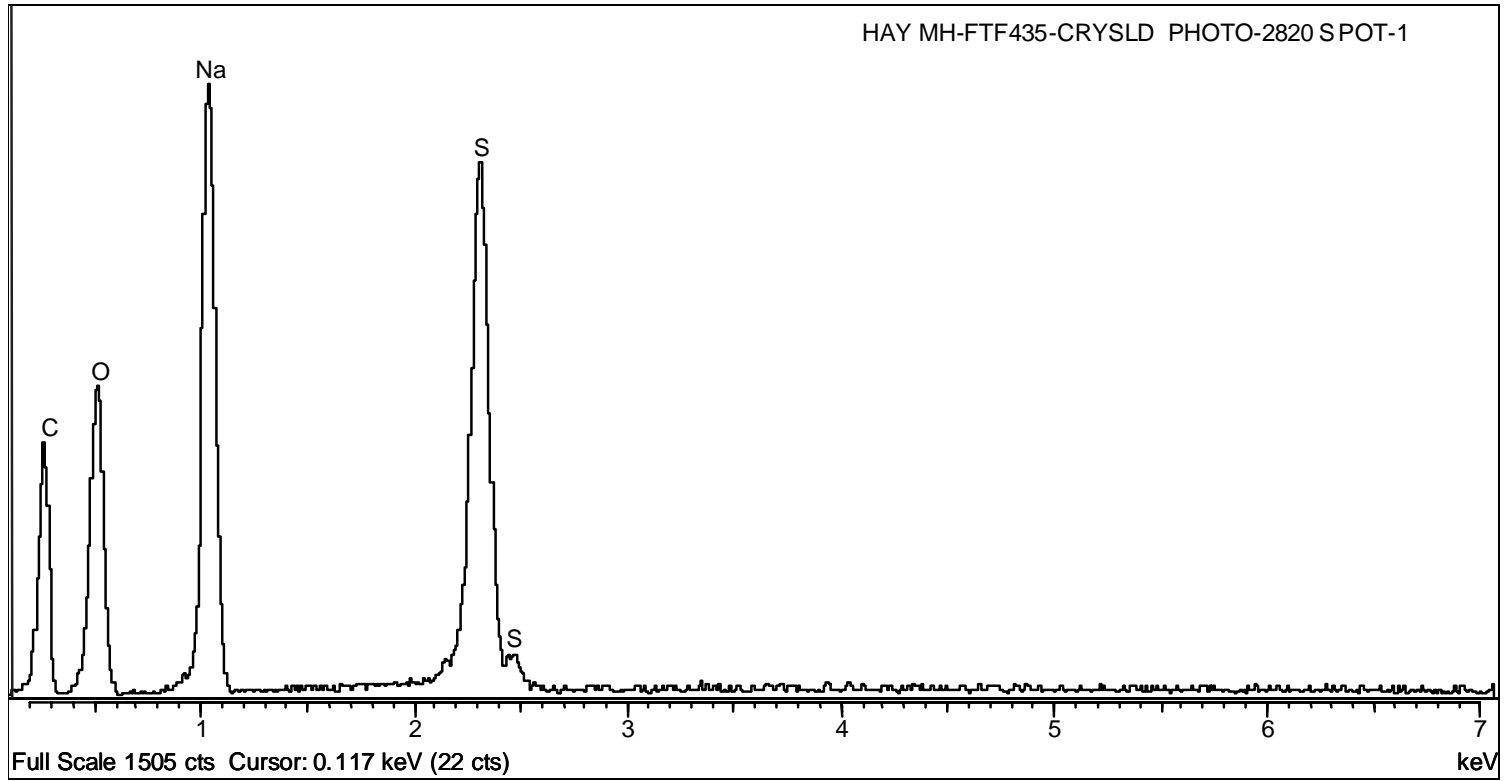

Figure 3.11 Spectrum of Spot 1 from Figure 3.10 


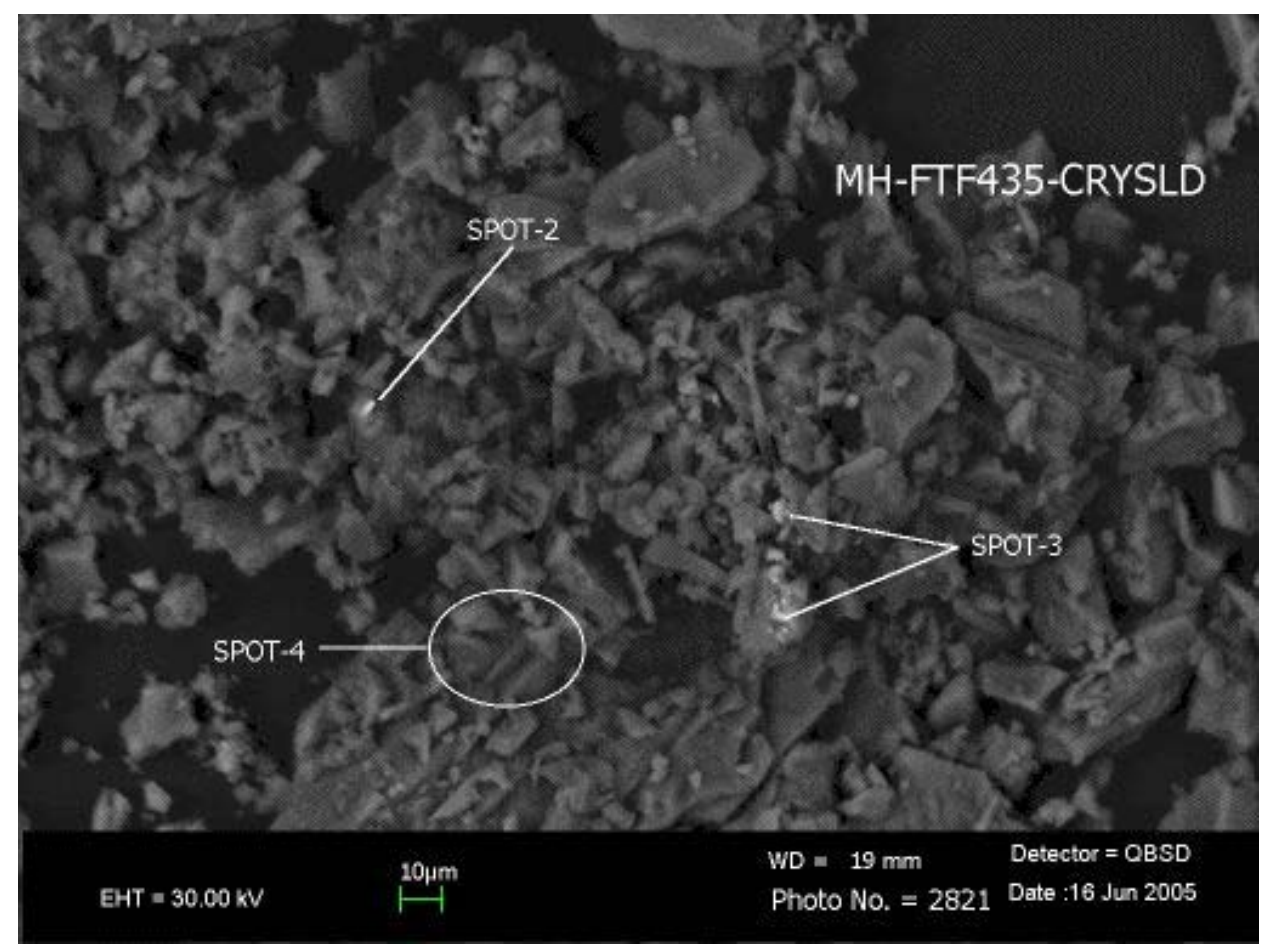

Figure 3.12 SEM Micrograph of Solids from Tank 4F Sample FTF-435 (375X Magnification)

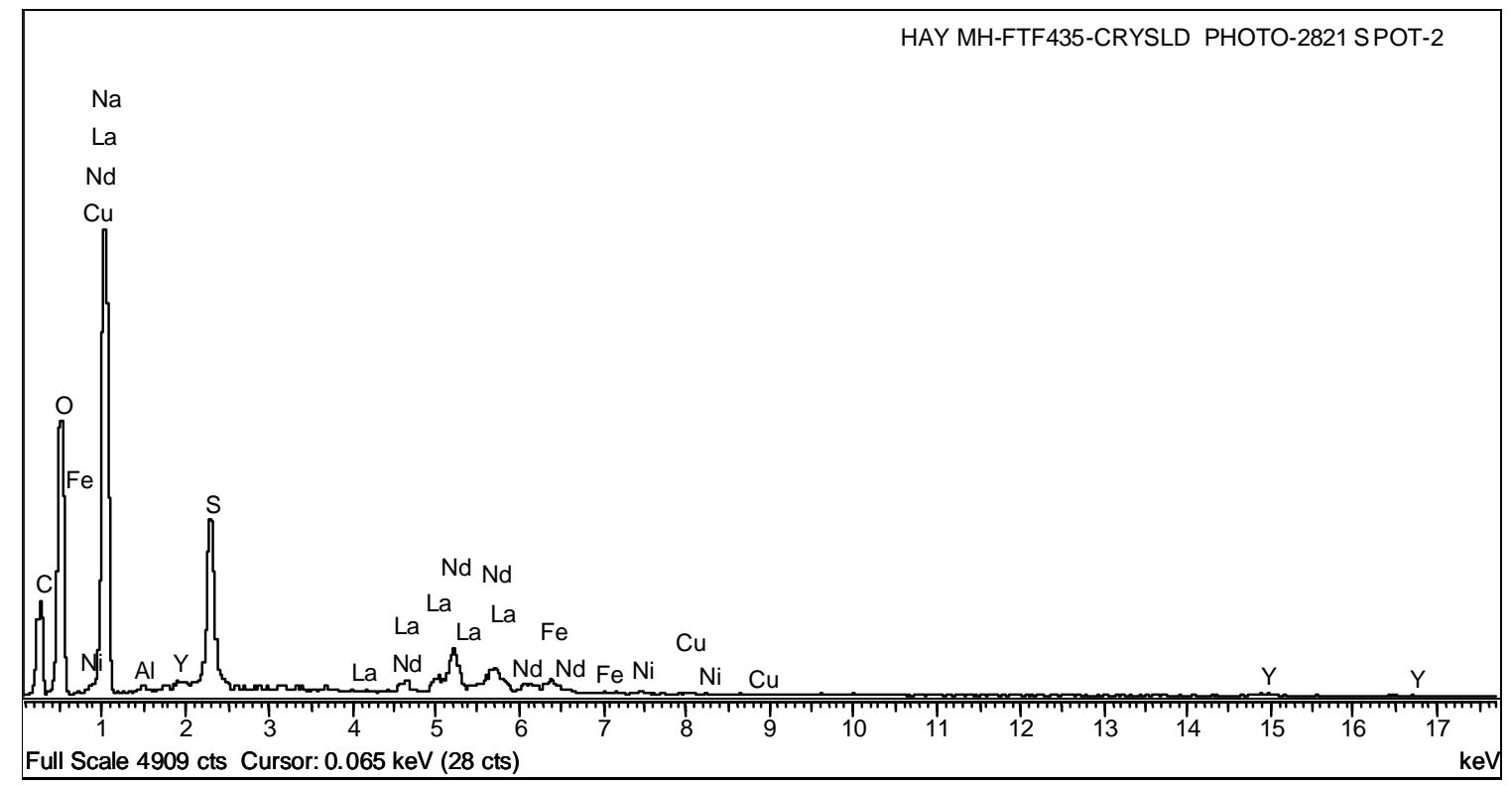

Figure 3.13 Spectrum of Spot 2 from Figure 3.12 
WSRC-TR-2005-00441, REV. 0

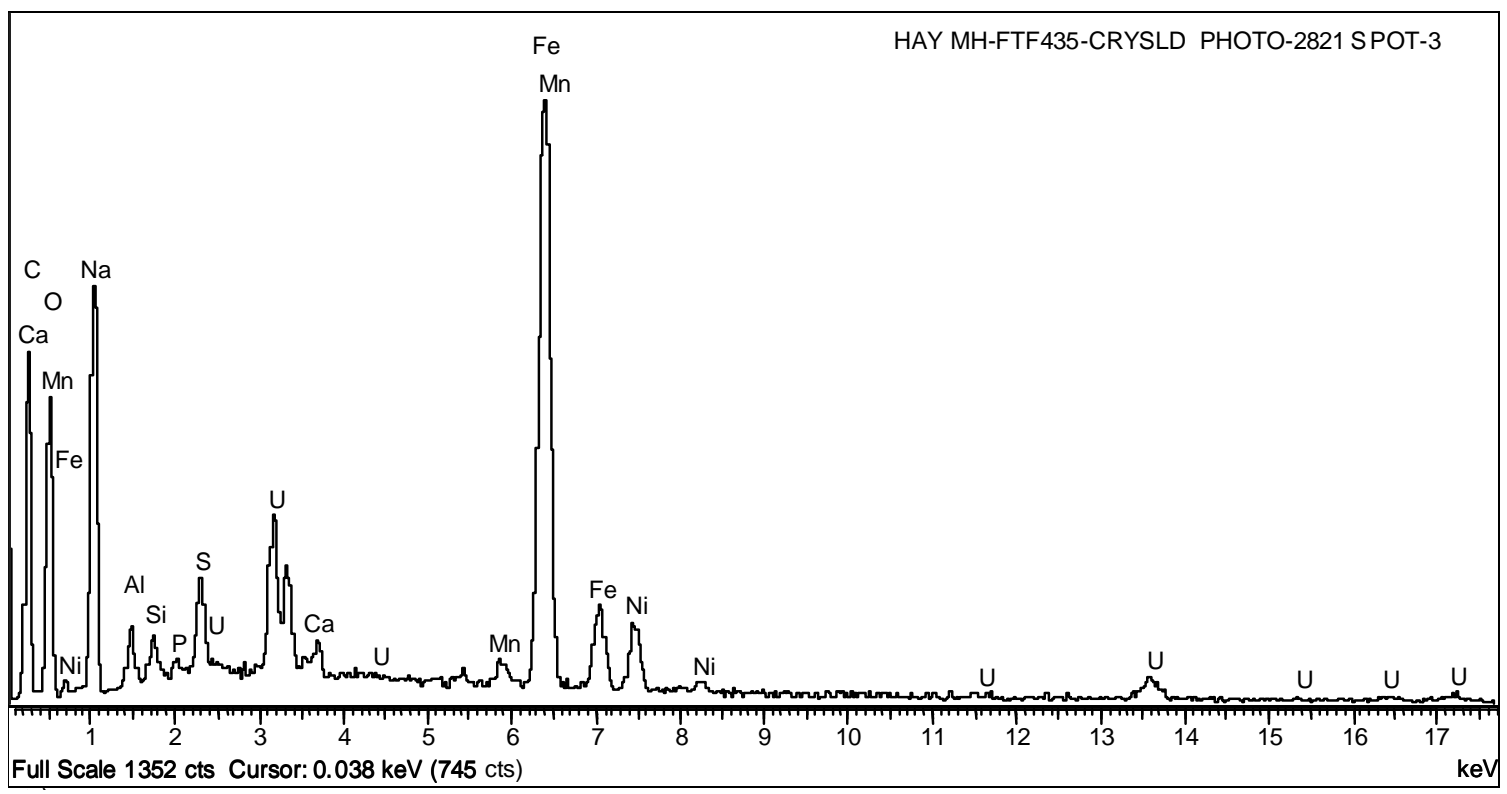

Figure 3.14 Spectrum of Spot 3 from Figure 3.12

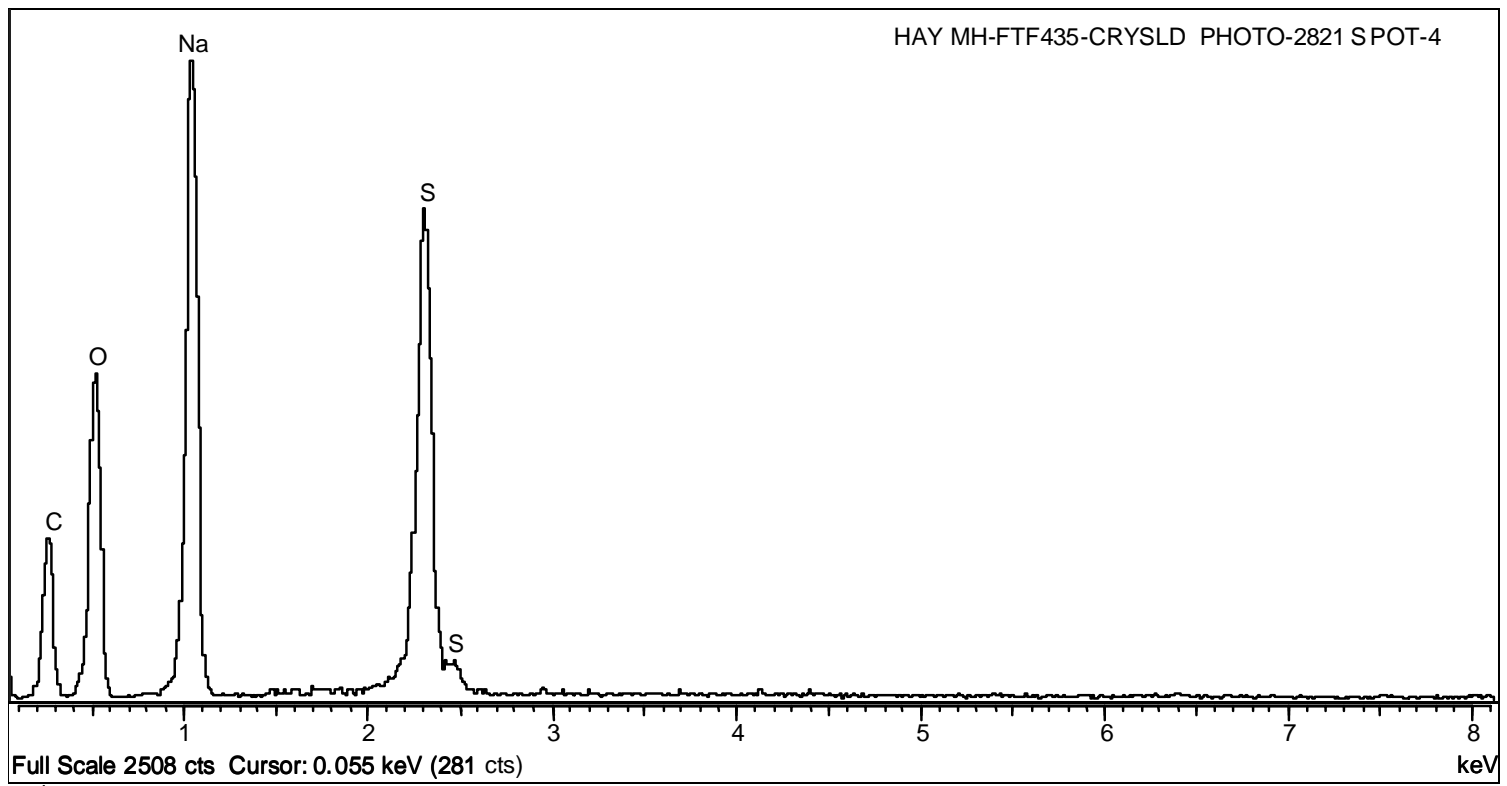

Figure 3.15 Spectrum of Spot 4 from Figure 3.12 
WSRC-TR-2005-00441, REV. 0

\subsection{BURKEITE SOLUBILITY TESTING}

\subsection{BACKGROUND ON BURKEITE SOLUBILITY}

Prior to testing, a literature review on the solubility of Burkeite was conducted. The review of the scientific literature and on-line sources found that Burkeite solids formation was a problem encountered in the pulp and paper industry. The spent cooking chemicals (black liquor) from the pulping process must be concentrated before proceeding through the recovery cycle. The recovery cycle converts the black liquor into white liquor that can be reused in the pulping process. The black liquor contains high concentrations of carbonate and sulfate. Burkeite formation in the black liquor evaporators leads to lower production rates due to the downtime required to remove the deposits. A warm water flush removes the Burkeite "soluble scale" from the evaporator. ${ }^{13,14}$

Most of the solubility data for Burkeite in the scientific literature relates to the temperature range found in evaporators (i.e., $>100^{\circ} \mathrm{C}$ ). Lower temperature data generally does not include the presence of $\mathrm{NaOH}$ in the solutions. No information was found that would be directly applicable to the current composition of Tank 4F. For this reason, a predictive thermodynamic modeling package, OLI System's Environmental Simulation Program (ESP) was used to evaluate the solubility of Burkeite in Tank 4F supernate diluted with various amounts of inhibited water. The ESP database contains Burkeite and therefore can be utilized to model the solubility. A simple model was set up in ESP with the purpose of determining the amount of dilution of Tank 4F supernate required to solubilize Burkeite prior to beginning an experimental study in the Shielded Cells.

The scenario used for the model development entailed decanting the supernate from Tank 4F to near the surface of the Burkeite solids layer and adding back inhibited water in various amounts. This model assumed a single contact with the diluted supernate. For the purposes of the model, the tank was assumed to contain a 6" layer (16.5 Kgal) of Burkeite on the bottom with a 6" layer of Tank 4F supernate above. This scenario leaves out the detail of the 45" of sludge beneath the Burkeite layer in Tank $4 \mathrm{~F}$ which contains interstitial supernate ( $>75 \%$ by volume). The assumption of the 6" layer of Burkeite was based on the 6" plug of solids found in core sample FTF-434. In all probability, the Burkeite layer varies in thickness across the tank. The average thickness may be more or less than 6”.

A simple mixer unit model was set up in ESP with two inputs. Input 1 represents the Tank 4F supernate and Burkeite layer. The composition of this input stream was set to provide the 1:1 ratio of Burkeite solids to supernate. Input 2 to the mixer unit was an inhibited water stream composed of $0.015 \mathrm{M} \mathrm{NaNO}_{2}$ and $0.010 \mathrm{M} \mathrm{NaOH}$. The flow of the inhibited water stream was iteratively increased until all of the Burkeite solids dissolved. These runs were done isothermally at $30{ }^{\circ} \mathrm{C}$. A temperature of $30^{\circ} \mathrm{C}$ was used since this is the lowest temperature at which Burkeite is thermodynamically predicted to form. Both the PUBLIC database contained in ESP and a private database WTPBASE were evaluated using version 6.7 of ESP. 
Using the ratio of the input stream volumes, where the Burkeite volume and the supernate volume each equate to a 6" layer in the tank, the model predicted that 44 " of inhibited water would be required to dissolve all of the supernate. A more detailed model predicted 60 " of inhibited water would be required to dissolve all of the Burkeite in Tank $4 \mathrm{~F} .{ }^{15}$

For the purposes of the experimental testing of the Burkeite solubility, an equivalent of 60" plus 20\% excess was chosen (i.e., 72” of inhibited water). This equates to a ratio of 1:1:12 for the volumes of Burkeite solids, Tank 4F supernate, and inhibited water to be used in the test.

\subsection{BURKEITE SOLUBILITY TEST}

The Burkeite solubility test was conducted in the Shielded Cells with the damp crystalline solids from sample FTF-434. Approximately, 0.2g of the damp solids were placed in a glass vial. The sealed vial containing the Burkeite solids and vials containing Tank 4F supernate and inhibited water were placed in an oven at $40{ }^{\circ} \mathrm{C}$ to ensure all materials were at the same temperature. A volume of Tank 4F supernate equivalent to the volume of Burkeite solids was added to the vial containing the Burkeite solids. A volume of inhibited water equivalent to 12 times the volume of Burkeite solids was then added to the vial containing the Burkeite solids/Tank 4F supernate. The inhibited water addition to the vial was done slowly down the side of the vial to minimize mixing. During the test every effort was made to minimize mixing when the vial was removed from the oven for observation. The temperature was maintained at $40{ }^{\circ} \mathrm{C}$ throughout the test except for short periods when the vial was removed from the oven to make additions or record observations.

Figures 3.16 through 3.22 follow the progress of the solubility test. The following observations were made during the test:

- The solution immediately became cloudy upon addition of the inhibited water to the Burkeite/supernate mixture.

- $\quad$ After 1 hour, a significant portion of the Burkeite solids had dissolved and the solution was still cloudy.

- $\quad$ After 2 hours, most of the solids appear to have dissolved and the solution was still slightly cloudy.

- $\quad$ After 15 hours, all of the Burkeite solids had dissolved and the solution was clear. A small amount of fine dark particles were visible in the bottom of the vial.

The results of the Burkeite solubility test confirm that a ratio of 1:1:12 for the volumes of Burkeite solids, supernate, and inhibited water will dissolve all of the Burkeite. These ratios could be used to remove the $\sim 6$ " layer of Burkeite from Tank $4 \mathrm{~F}$ with no mixing. However, both of the ESP models and the solubility test neglected the sludge layer beneath the Burkeite crust in Tank 4F. Settled sludge in SRS high-level waste tanks usually contains greater than $75 \%$ interstitial supernate by volume. If the supernate in the sludge layer should mix into the 
solution used to dissolve the Burkeite, significantly more inhibited water would be needed to dissolve the Burkeite. Additionally, the average thickness of the Burkeite layer across the diameter of the tank may be thicker or thinner than the 6" assumed for modeling purposes. The 6" thickness assumed for the Burkeite layer was based on the 6" plug of solids found in one core sample. An average thickness greater than 6" would obviously increase the amount of water needed to dissolve the Burkeite. 


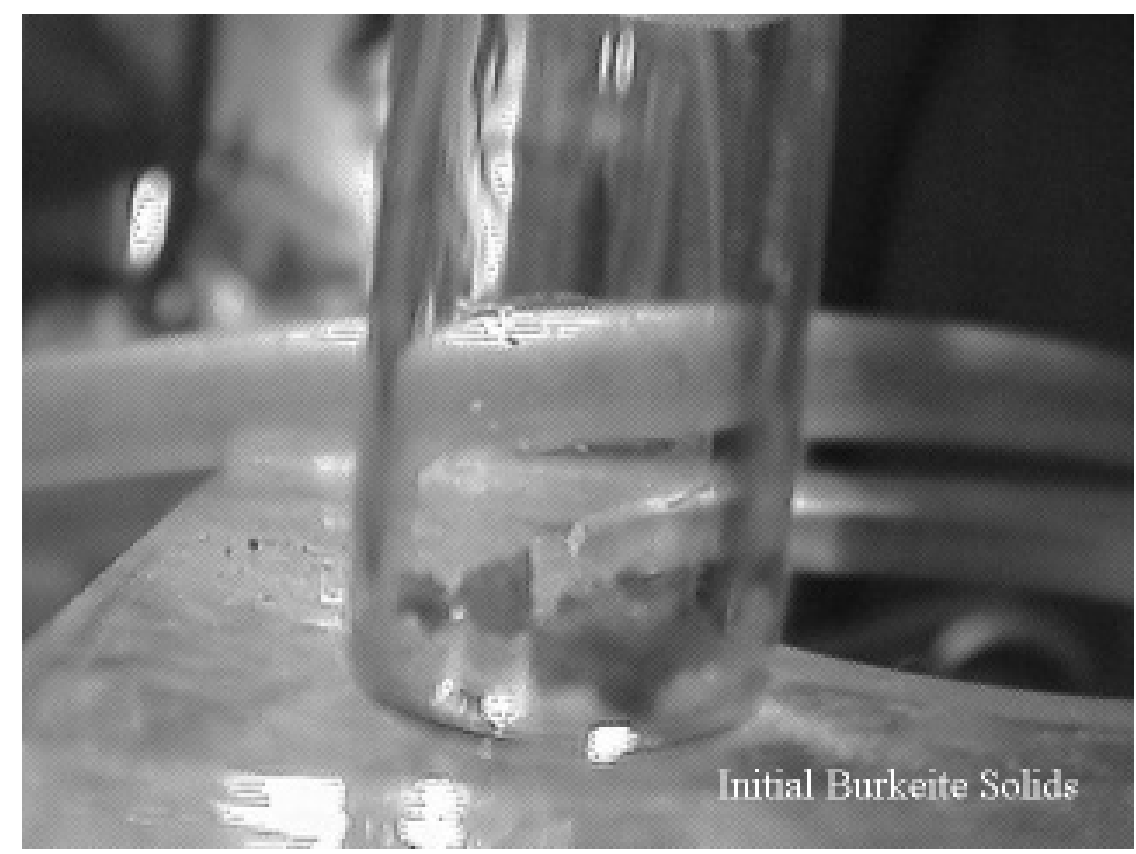

Figure 3.16 Initial Burkeite solids placed in the glass vial.

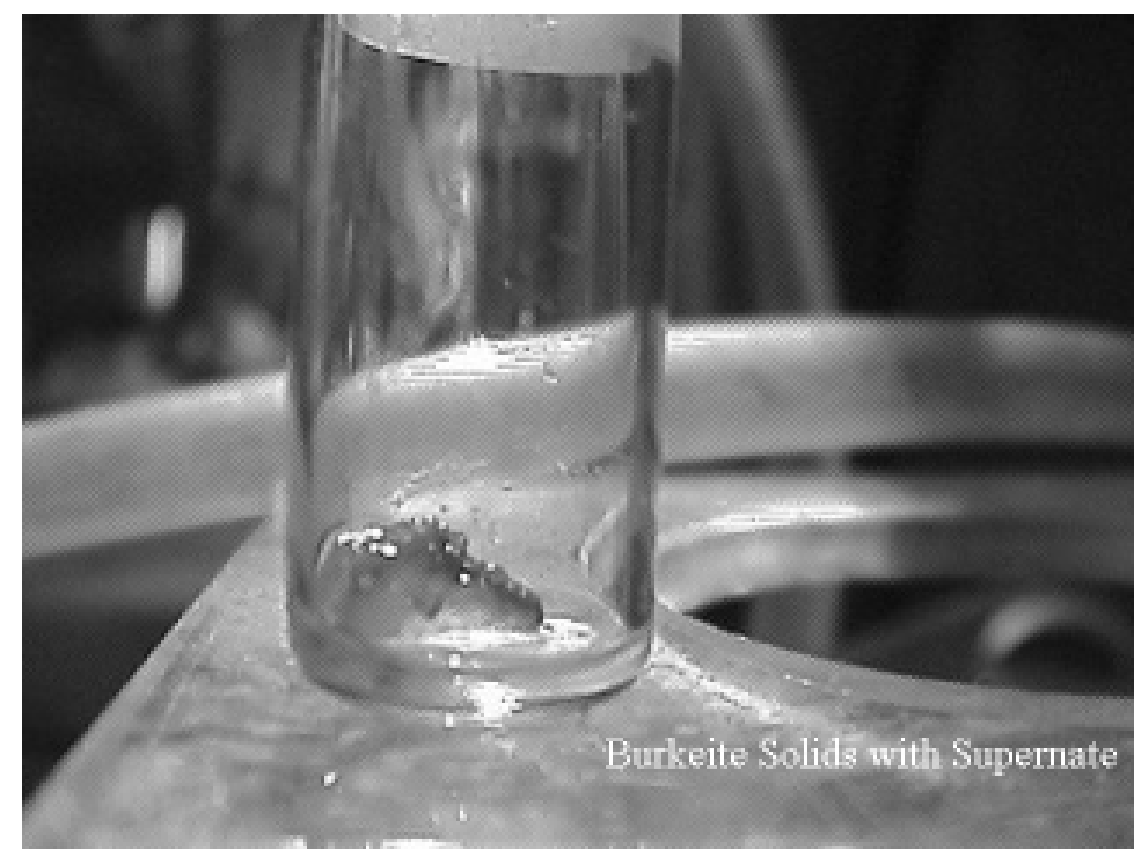

Figure 3.17 Burkeite solids after the addition of Tank $4 \mathrm{~F}$ supernate at $40{ }^{\circ} \mathrm{C}$. 


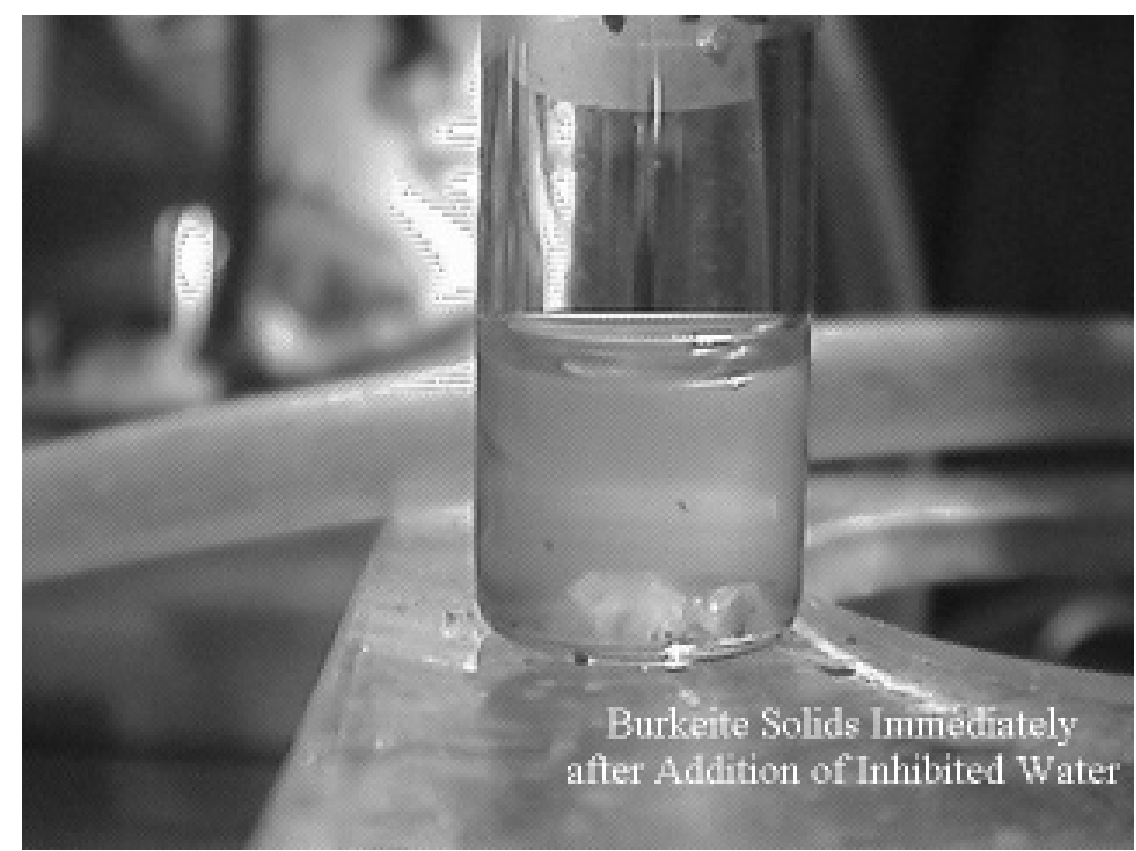

Figure 3.18 Burkeite solids after the addition of inhibited water at $40{ }^{\circ} \mathrm{C}$.

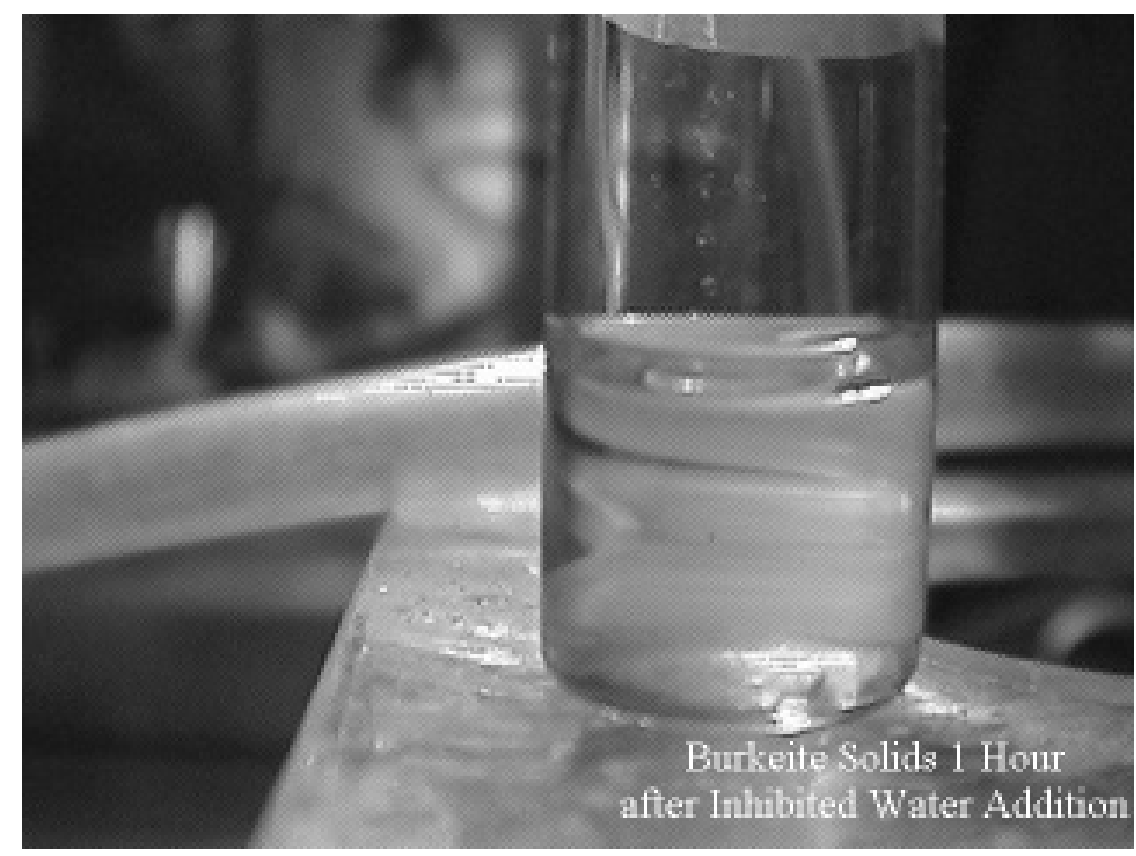

Figure 3.19 Burkeite solids after 1 hour at $40{ }^{\circ} \mathrm{C}$. 


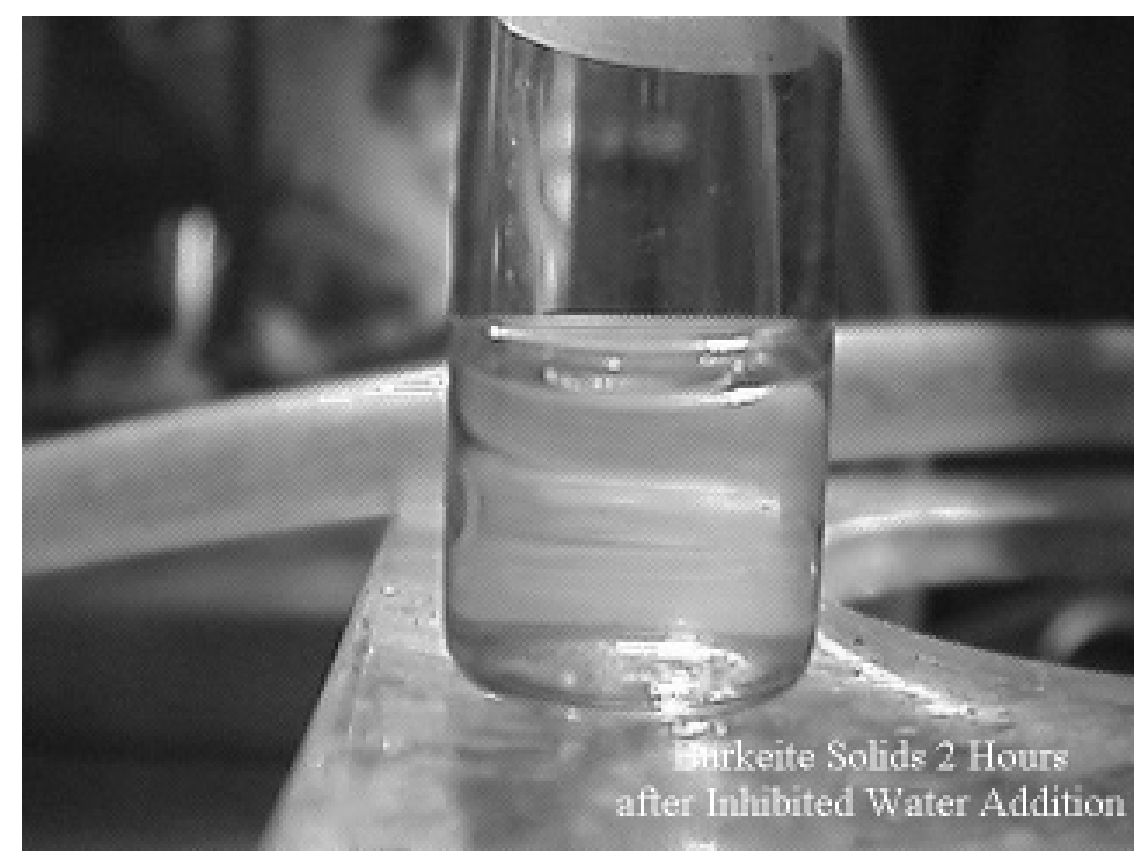

Figure 3.20 Burkeite solids after 2 hour at $40^{\circ} \mathrm{C}$.

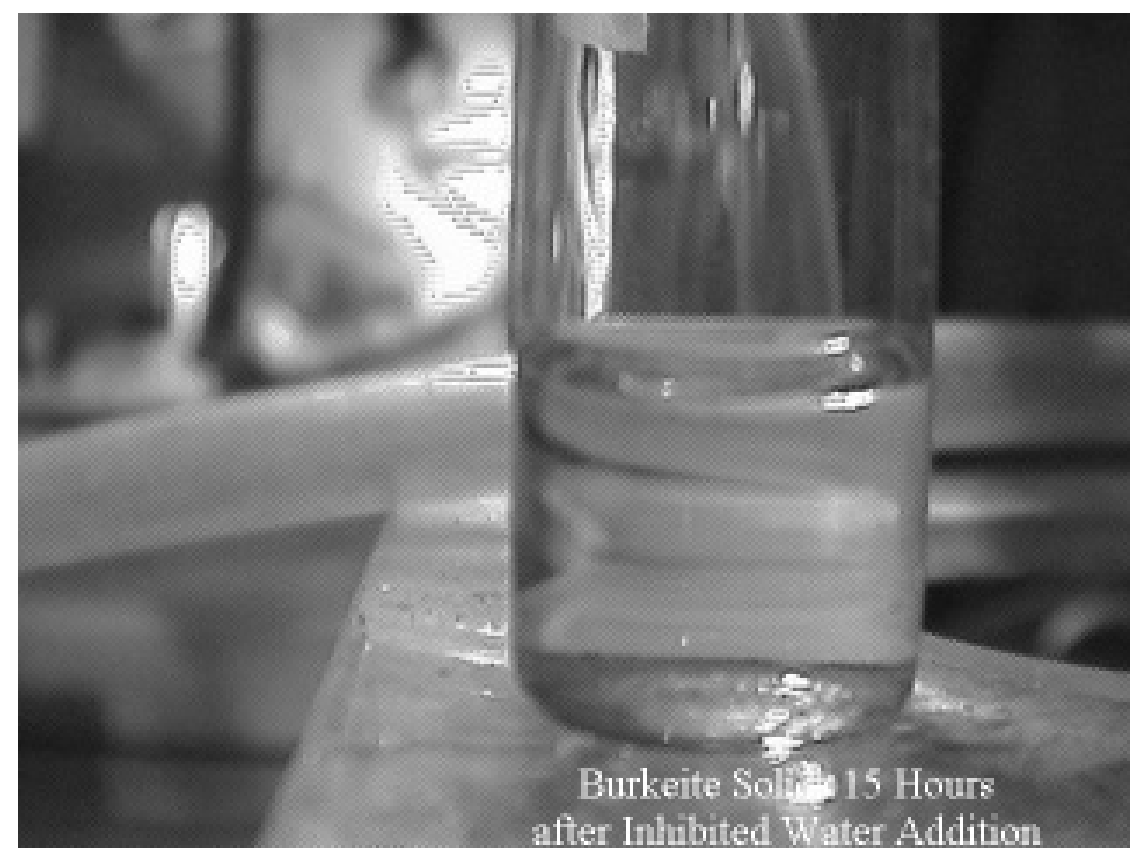

Figure 3.21 Burkeite solids after 15 hour at $40{ }^{\circ} \mathrm{C}$. 


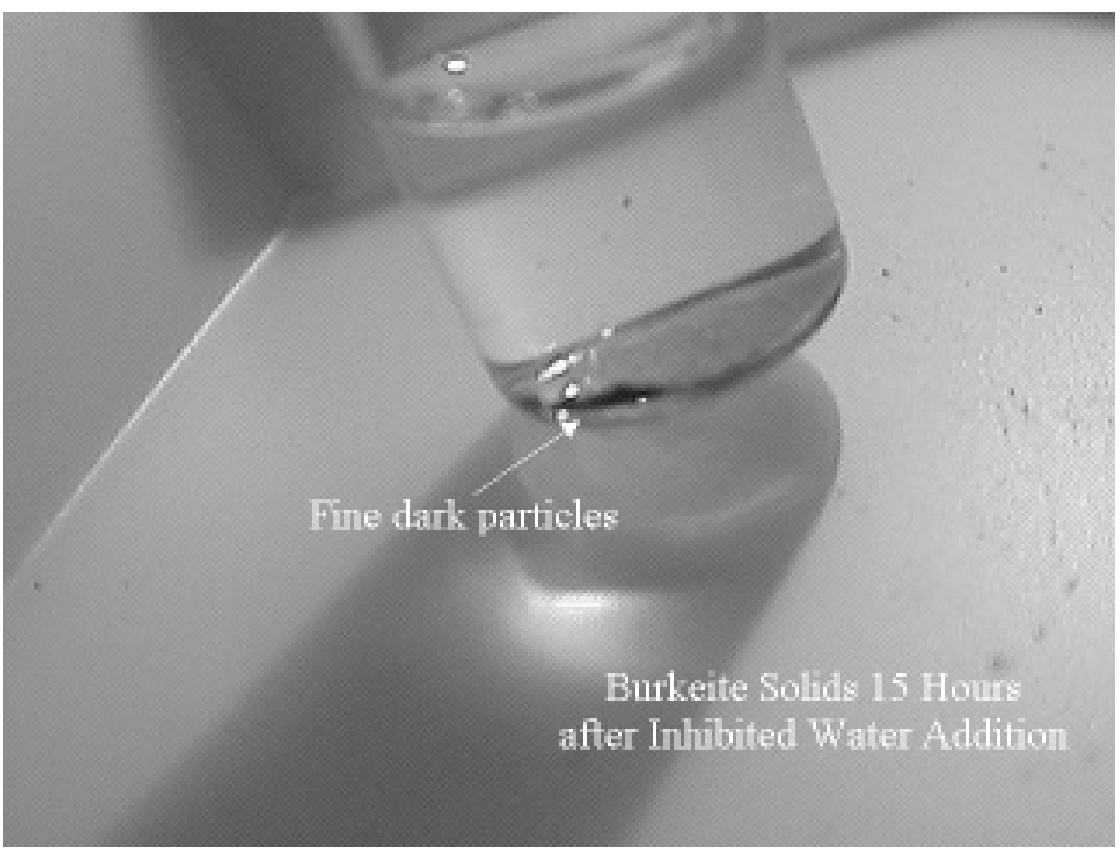

Figure 3.22 Burkeite solids after 15 hour at $40{ }^{\circ} \mathrm{C}$. 


\subsection{GENERAL DESCRIPTION OF ANALYTICAL PROCEDURES}

\subsection{INDUCTIVELY COUPLED PLASMA-ATOMIC EMISSION SPECTROSCOPY}

Samples were diluted as necessary to bring analytes within the instrument range. A scandium internal standard was added to all samples after dilution at a concentration of $2 \mathrm{mg} / \mathrm{L}$. Background and internal standard correction were applied to the results.

\subsection{ATOMIC ABSORPTION SPECTROSCOPY}

Mercury was analyzed by atomic absorption spectroscopy (AA) using the cold vapor technique. Samples were diluted as necessary to bring analytes within the instrument calibration range.

\subsection{ION CHROMATOGRAPHY}

For ion chromatography (IC), samples were diluted with a carbonate/bicarbonate diluent as necessary to bring analytes to within instrument calibration for anion analysis.

\subsection{FREE HYDROXIDE AND CARBONATE TITRATIONS}

Free hydroxide was determined by incremental inflection point titration. The titration curves were examined to determine the free hydroxide concentration. Carbonate was determined by precipitation using saturated barium chloride. The precipitate was dissolved in acid and the carbonate concentration determined via back titration 


\subsection{REFERENCES}

1. N. Elraheb, Sampling, Analysis, and Characterization Plan to Support HLW Tank 4 Waste Removal and Sludge Batch 4, CBU-LTS-2005-00031, Rev. 1, April 27, 2005.

2. Q. Nguyen, Technical Task Request: Tank 4 Sample Evaluation/Characterization, HLE-TTR-2005-046, February 11, 2005.

3. High Level Waste Engineering Monthly Data Report, WSRC-RP-94-383-11, November 1994.

4. NTank 4 spreadsheet from the Waste Characterization System Database.

5. M. S. Hay, W. R. Wilmarth, W. D. King, and J. M. Pareizs, Identification of Possible Tank 4F Solids, SRNL-WHM-2004-00015, December 8, 2004.

6. M. S. Hay, Scoping Plan for the Characterization of Tank 4F Samples, SRNL-WPT2005-00020, Rev. 2, August 18, 2005.

7. M. S. Hay, Analytical Study Plan for the Characterization of Tank 4F Samples, SRNL-WPT-2005-00056, May 10, 2005.

8. C. J. Coleman, R. A. Dewberry, M. F. Bryant, J. J. Gemmill, SRL's Performance in Round Robin \#6 - Analysis of Simulated Defense Waste Glass (U), WSRC-TR-91187, Rev. 0, May 31, 1991.

9. M. S. Hay, T. B. Edwards, Statistical Analysis of ESP Verification Test Samples, WSRC-RP-94-1224, November 4, 1994.

10. Shi, B., and R. W. Rousseau, Structure of Burkeite and a New Crystalline Species Obtained from Solutions of Sodium Carbonate and Sodium Sulfate, J. Phys. Chem., 8107,6932-37, 2003.

11. Shi, B., Frederick, J. Jr., and R. W. Rousseau, Nucleation Growth, and Composition of Crystals Obtained from Solutions of $\mathrm{Na}_{2} \mathrm{CO}_{3}$ and $\mathrm{Na}_{2} \mathrm{SO}_{4}$, Ind. Eng. Chem. Res., 42,6343-47, 2003.

12. Shi, B., Frederick, J. Jr., and R. W. Rousseau, Effects of Calcium and Other Ionic Impurities on the Primary Nucleation of Burkeite, Ind. Eng. Chem. Res., 42, 2861-69, 2003.

13. Betz Handbook of Industrial Water Conditioning, $8^{\text {th }}$ Ed., 1980, Betz Laboratories, Inc., Trevose, PA. 
14. Shi, B., and R. W. Rousseau, Crystal Properties and Nucleation Kinetics from Aqueous Solutions of $\mathrm{Na}_{2} \mathrm{CO}_{3}$ and $\mathrm{Na}_{2} \mathrm{SO}_{4}$, Ind. Eng. Chem. Res., 40, 1541-47, 2001.

15. Q. L. Nguyen, Tank 4 Burkeite Dissolution Flowsheet, CBU-PIT-2005-XXXXX, Rev. 0, September 15, 2005. 